\title{
THE PIONEERS OF
}

MASHONALAND - ADRIAN DARTER= "ONE OF THEM" 


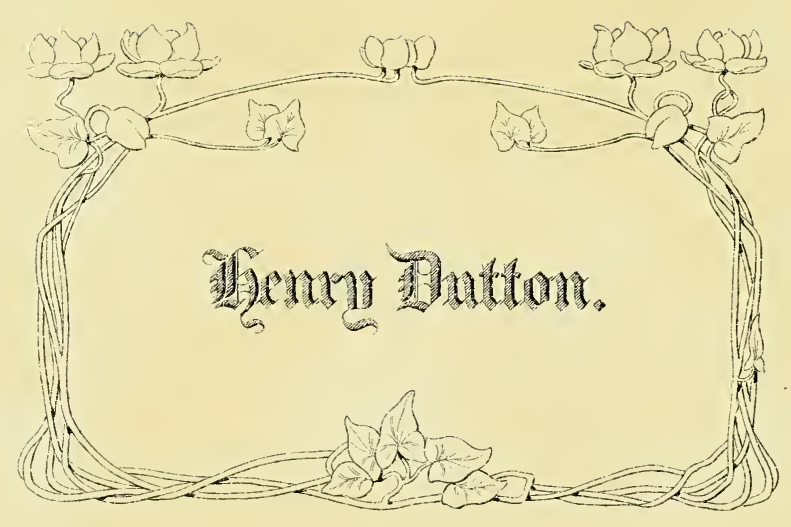




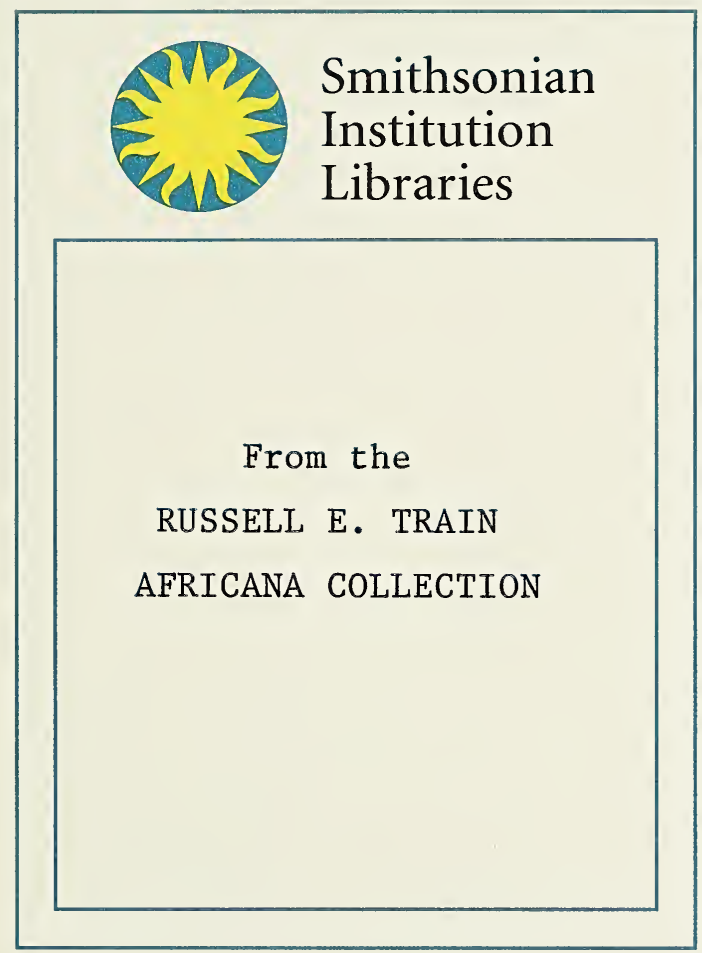






\section{THE PIONEERS OF MASHONALAND.}





\section{THE PIONEERS OF}

MASHONALAND

(Men who made Rhodesia.)

BY

\section{ADRIAN DARTER}

(One of them.)

\footnotetext{
"Breathes there a man with soul so dead, Who never to himself hath said,

This is my own, my native land?"

Scott.
}

LONDON : SIMPKIN, MARSHALL, HAMILTON, KENT \& CO., LTD.

1914. 
COPYRIGHT
1914. 


\section{INTRODUCTORY.}

THE story of the Pioneers of Mashonaland is a part history of the British Empire told by a Pioneer who helped to place the Union Jack at Salisbury, twenty-three years ago.

The argument and proofs described on these pages conclusively prove Great Britain's title to the land and upset the pretentious rights of the Chartered Company.

The tale of the Pioneers ceases after a year's occupation, because it is not a twenty-five years' history, which would run into volumes. As there will, possibly, be a law-suit, the Crown $v$. Chartered Company, over the title of the land, the subject is of the moment, and one recalls the impeachment of Warren Hastings with regret. There is no animosity to the Chartered Company. The good work of the Company for the Empire is acknowledged. For the Empire is the key-note, 
viii

INTRODUCTION

and the Empire must not forego her rights to these millions of acres and again place her Pioneers in bondage to a Company. A Rhodesian's cry is freedom, and his ambition to be able to say, "Sum Britanicus civis."

The "The Nominal Roll of the Pioneer Corps" has been supplied by the courtesy of the Secretary of the B.S.A. Company.

THE AUTHOR. 


\section{CONTENTS.}

Chapter I.

Formation B.S.A. Company-The News-en route-An interview with Mamatola-Queen-"SHE" . .

Chapter II.

Lieutenant Nicholson-Pioneers enlisting-A Welshman --Trek to Mafeking-Kruger's early home-Reminiscences of Oliphant's Nek-A Colonial Joan of ArcAustralians . . . . . . . . . . . . .

Chapter III.

Boer Tautas-Meeting the Johannesburg contingent"Salted" horses-Mafeling-Rhodes-Recollections of Mafeking-equipment . . . . . . . . . 15

Chapter IV.

Journey to Base Camp-Spreckley-Molopolole-Charlie Masters-The camp at Macloutsi-Lobengula . .

\section{Chapter V.}

Grimmer-Coryndon-other Pioneers-Major Johnson -Captain Heany-Borrow, Colquhoun, Judd, Berkeley -Shangani heroes-warriors knowing how to die .

Chapter VI.

Pioneer Officers-R.S.M. King-Lord Methuen-"Keenness" of the men-Diseases of cattle . . . . . . 36 
Chapter VII.

PAGES.

Grobelaar-Khama-historic trading . . . . .

Chapter VIII.

Livingstone and Moffat-Khama and LobengulaGordon Cumming . . . . . . . . . . . . 53

Chapter IX.

Lieut.-Col. Pennefather-Captain Forbes-Captain Heyman-The Vauder Byls-Officials at BuluwayoRadi Kladi-The cutting of the road-SelousSentry's dilemma . . . . . . . . . . . . 68

\section{Chapter X.}

The road cut 50 miles-Camp life-Selous and LaerThe Burnetts-Darling and diet-Father HartmanM'tibi's Kraal-Bubye-Selous at home . . . .

Chapter XI.

Nuanetsi - Chibi's - Lundi - Hippopotami Hunt Burnetts again - Colenbrander - Lieutenant-Colonel Pennefather . . . . . . . . . . . .

Chapter XII.

Anxious vedettes-Tokwe-Venables and FinucaneProvidential Pass - Victoria founded - A football match-Zimbaleye-Ruined cities-Mashonas-their country and habits

\section{Chapter XIII.}

200 miles - Charter - Mount Wedza - 430 milesSalisbury-Union Jack hoisted-Pioneers as Prospectors. 
Chapter XIV.

PAGES.

Excelsior syndicate - Hartley Hills - Gedsema - Old workings-A night out with a hyena . . . . . . 112

Chapter XV.

"Bushed" for three days - Making roads again Pioneers' home at Gedsema - Mashonaland Main Reef-Fever-Lack of nourishment . . . . . . 122

Chapter XVI.

Lobengula's grace-50 per cent. dreams-Pioneers returning to Salisbury-Hospital-Dr. Tabiteau-Dr. Brett-Early arrivals-Death of Louis Vintcent . . 131

\section{Chapter XVII.}

The Chartered Company and transport-ManicalandGorweia and d'Audrada-Prospector's idea of the Foreign Office-Massikessi-Pioneers as traders . . 140

Chapter XVIII.

Five points against development-Umtasi-Return to Salisbury-Young Colquhoun . . . . . . 150

Chapter XIX.

The Sabi and early Arabians-Bleuded races-Monopotama - Early Portuguese - "Monty" Bowden Milestones of British pluck-Salisbury's growthFirst English church-Mother Patrick-First babyCecilia-Matabele sayings . . . . . . . . 156

Chapter XX.

Vorster - Adendorff trek - Dr. Jameson - "Doul" Zeedenberg-Colonel Ferreira . . . . . . . 168 


\section{Chapter XXI.}

PAGES.

Mistakes at Tuli-England's Ownership-Suzerainty granted by Lobengula, 1888 - Sir Henry Lock's Proclamation, 1891 - Chartered Company correspondence--Lobengula and the Company-The Lippert concession-The Colonial Office-How the Chartered Company disestahlished its charter and concessionGreat Britain's right to establish Crown Colony in 1893-The Union of South Africa-Copy of the Lippert Concession . . . . . . . . . . . 176

\section{Conclusion.}

The first Administrator leaves-Dr. Tabiteau-Dr. Rand - Pioneers' dissatisfaction - Rand, the People's Champion-Rhodes-B.S.A. Company's DirectorThe Company courting the Rhodesians-Mr. Rochefort McGuire as best man-Mother 50 per cent.-The traditions of the House of Commons-The spirit of Hampden . . . . . . . . . . . . . . . 191

Nominat Roll Proneer Corps. . . . . . . Appendix. 


\section{PIONEERS OF MASHONALAND.}

\section{Chapter I.}

Formation B.S.A. Company-The News-en route-An interview with Mamatola-Queen-"SHE."

Twenty-five years ago the British South Africa Company was inaugurated and received a Charter to administrate the country known as Mashonaland, which country was ruled by Lobengula, King of the Matabele, and Mashonaland was inhabited by remnants of tribes in constant dread of the raiding Matabele. An expedition to this country under the auspices of the Chartered Company was undertaken by a body of men under the guidance of Mr. Selous, the renowned elephant hunter. These men were enlisted as Pioneers, and it may be of interest to the public to read of this extension of the British Empire, and appended is the nominal rôle of the Pioneers.

It was at Christmastide in 1899 that the news reached me in the Thebena Valley of the Murchison range-situated in the North-Eastern Transvaal-that Cecil John Rhodes was forming an expedition for the occupation of Mashonaland. 
Tales of this Eldorado had long ago been disseminated amongst the Boers by a German explorer, Mauch, who had called it Ophir and King Solomon's Mines.

The rains had been early that year and malarial fever was rampant on the Murchison rangefever must be expected in all new countries.

I learnt that Nicholson had received a commission from Rhodes and had to enlist fifty border hunters. I was fired with an ardent desire to join, but my spirits were considerably damped, for I could not possibly qualify as a borderhunter, seeing that a year before, at the age of twenty-one, I was sitting in my father's countinghouse in Adderley Street, Capetown, adding up endless rows of figures in bulky day, cash and ledger books. My desk faced north, and the figures were so many dusky natives, and the redrulings were British troops marching in column and forming square, and the blots were elephants going to water-by the way, we had to initial our blots. Yes, the "wanderlust" was in me, and I had already at twenty-two got many miles away from the high stool of the Adderley Street office. I determined to see Nicholson, and to do so had to go south some sixty miles.

We-my then companions and I-decided to leave fever-stricken Thebena and go to Haenertsberg. We set out the next day accompanied by two natives carrying our kit. Haenertsberg was 
not more than thirty miles ahead, but we decided to do it in two stages; because I was suffering from dysentry, and it would have been too severe for the carriers at this season.

A mistake made in the morn harasses us at midday and brings us more trouble at night, so the follies of youth are paid for in mature years. Not being able to swim the river-due to the mistake of getting ill-I had to proceed the way the natives did. High up a tree had thrown a giant branch across the stream and it met the arms of a vis-à-vis. The native postman brought letters this way to the prospectors; forty feet in the air and slippery from the tread of natives for years. I did not know what it was like until I got up there and quite realized why the natives had told me to take my boots off, for fifteen feet had to be crossed without any assistance of branch to hold on to steady you, and the trunk was as smooth as polished mahogany. The nativesthey are fine fellows these mountain boys-had gone across with the kit on their heads, and that would help to balance them. Anyway, if natives could cross there was no reason why a white man should not-I got the other side safely. It is in moments like these that the desk in Adderley Street with its padded high stool came back vividly as a safe crib, but when you had steeled yourself for the deed before you, and had done it, the vision dispersed, and pure mountain air 


\section{PIONEERS OF MASHONALAND.}

chased away the hankering after civilisation, which had rung in your head to the melody of Gilbert's "stick to your desk, etc."

That night we slept in Mamatola's Kraal. She was Queen of the Majaji tribe, who were always governed by feminine Sovereignty, and-it is said - that it was this tribe that gave Rider Haggard his foundation for "She." Mamatola could not see us that night, but gave us a good hut to sleep in and sent us food. The Court diet was red millet, well-cooked and served on a wooden platter. I found it excellent.

We were up betimes in the morning and strolled round the stadt - a small one, as the tribe was scattered. We were amused at the stockade around the stadt, which included at intervals the wooden image of a man's head and shoulders. They were bald-headed idols, and years later in Buluwayo when asked who Kaffir Wilson resembled, I immediately answered the idol in the stockade of Mamatola's kraal. No ofience to my old friend, Kaffir Wilson; but it was the shape of his head and the very short fair hair that gave the resemblance. I must mention here that our esteemed Buluwayan rendered such sterling good service in the Great Boer War that Lord Kitchener chose him as Colonel for Kitchener's: Fighting Scouts.

It was after breakfast that a messenger informed us that the Chieftainess would like to see. 
us. Here was a Court interview and there was a Court romance, or scandal, as you can adjudge for yourself later when I divulge the secret. Mamatola was a little plump woman not without dignity of office. She received us standing. Stalwart Shangaans stood respectfully behind and around her. Having exchanged greeting I asked to see the Royal Babe, and the little snuff-coloured, or rather coffee and milk-hued mite, was brought to me. I found the Royal infant suffering from opthalmia, as most kaffir babes do, due to flies nestling on their eyes, and natives do not trouble to fan them away or bathe the eyes with soothing lotion. The tea-leaves diffused that morning for our breakfast-for which I had sent-I applied to the puling Black and White.

"Has your husband taught you to drink tea?" I asked the Queen.

"Yes, M'jorg had."

"You must save the leaves and bathe your baby's eyes with it; but you must get a woman to keep the flies away."

The Queen appointed a Royal nurse on the spot and bade her do my bidding.

Her Majesty was well-disposed and gracious to the white lords of the Thebena valley-that is us - for the father of her child was M'Jorg-I give you his Kaffir name- one of the earliest prospectors of this locality. Of course we disapproved of George's marriage morally, or as the Queen called 
him M'Jorg and the tribe gave him that appellation in consequence, but as to be known as M'Jorg's friend meant getting native labour readily from this tribe, we approved the situation from its business aspect. M'Jorg, however, was a disappointment. According to the native law of this tribe the Queen had the right to choose her own husband. The man chosen became the Prime Minister. M'Jorg had supplanted the late Prime Minister in the Queen's affections, and by native custom was the lawful Prime Minister. Well, he refused the job but stuck to the marriage. Thus the Leader of the Opposition-the supplanted one-was the working Prime Minister and M'Jorg: was content to work his claims as a simple prospector, and yet he was the Buckingham of the situation. I do not know who eventually supplanted M'Jorg-I refer to a black politicianbut as a Court favourite he was a distinct failure, and his romance cannot compare with that of Leicester, Essex, Mazarin or the Russian Dragoon. 


\section{Chapter II.}

Lieutenant Nicholson-Pioneers enlisting--A WelshmanTrek to Mafeking-Kruger's early home-Reminiscences of Oliphant's Nek-A Colonial Joan of Arc-Australians.

At Haenertsberg, as there was no coach going south for a few days, I hired a bicycle and rode to Ally Marais' farm, where Nicholson dwelt. To my delight I ascertained that Cecil Rhodes had countermanded border-hunters and had instructed Nicholson to recruit British subjects. Nicholson told me that he had met Mr. Rhodes at Capetown and that he had at first got the promise to lead a party of fifty Boer families into Mashonaland to settle there. The Transvaal Government would not sanction or encourage such a trek, as the Matabele were dreaded as a blood-thirsty race, and the expedition was looked upon as leading to drastic consequences, if not annihilation. Nicholson tested my riding and shooting that afternoon, which he pronounced satisfactory, and I promised to arrive in a few days, for he had a contract to buy "salted " horses for the Charter Company and would be glad of assistance. That night I slept at Nicholson's store, and a rat demolished my cycling stockings whilst I slumbered. It gave me a very good idea of what a rodent could do in a 
night, and I left the remnants behind to complete the nest-making, cycling back in striped cotton stockings, obtained from the Kaffir truck of the store, and the only available hose procurable, which had been stocked with the idea of luring a dusky damsel to purchase. I returned with the coach, and Nicholson had plenty of work for me. He had already purchased several horses and they were arriving daily. Nicholson was a little man with a high commercial nose, a pointed beard, and he was a hard rider. These days I was in the saddle most of the time after horses, and generally was accompanied by Grobelaar, Nicholson's brother-in-law, as fine a specimen of vigorous Christian humanity as ever breathed; and a typical Voortrekker. Many a "tip" he gave me in these days that came useful to me as a Pioneer of Mashonaland. My companion recruits were daily arriving: first came Fred Nesbitt, who was a tall, slim, saturnine man, well in the forties, had seen service in the Kaffir wars of the Eastern Province of the Cape Colony, and was soon "bossing" us, as an old soldier will; and, moreover, he was a friend of Nicholson. Next followed Alick Halkett, an old Diocesan College boy, and against whom I had often played cricket in the Inter-Collegiate matches of the South African and Diocesan Colleges. We were old chums, and he also had come from Thebana Valley. Lorry Chiappini-known as Chips-had come up from Johan- 
nesburg. Chips was a very fine handsome young man of twenty-five years and of the Italian type. With his slouch hat set nonchalantly on his head and his open shirt he might have posed as a young Garibaldian, or graced a barrel-organ with equal success. Harry Nesbitt, nephew to Fred, tall and fair, arrived with a sword; he also had seen service, and gave us exhibitions of sword-play that won our hearts. He became a Sergeant in " $A$ " Troop of the Pioneers. Pattinson, a tall, dark man, with heavy side-whiskers, and a prematurely bald pate. Fred Hunter, an Englishman, of very fair complexion, an accountant, green to this work but with the adaptability of his race, he was soon "coming along." Fletcher, a Welshman, friend of Fred Nesbitt, a medium-sized man, neither fair nor dark, glib of tongue, quick of perception.

Fred Nesbitt and Fletcher had been prospecting for gold in the Waterberg district. Fletcher had brought a horse to sell to Nicholson, but he did not purchase it. He agreed to let Fletcher bring his own mount. Fletcher, with the pertinacity of his countrymen, sold that horse to another Charter Company official. I will tell Fletcher's story here and let him speak to you :-

"He asked me if I would guarantee my gee-gee. I most certainly would. Then he queried its docility."

"Docile," said I, "when I was prospecting in Waterberg 'Taffy'-the pony's name-and I 
shared the same tent. I never used a tent-pole. I would throw the tent over 'Taffy' and go to sleep next to him. We never had an accident, nor did I catch cold, for ' Taffy' never moved whilst I slept, in case he might trample on me or pull the bed-clothes ofil me."

Fletcher told me of the custom of "blanketing " girls in Wales. I wondered if that ancient custom still was practiced, for one had to be wary of what he told you. He wrote cheerfully to his wife-he told me he had a wife in Wales-of his camp-life in Waterberg, and how daily at sundown he wended his way, on a steep bridle-path on the edge of the mountain cliff with a swift river flowing at the mountain's base. Frequently a lion disputed the right of way with him, on that path, and to jump over the cliff into the water was out of the question, for the gaping mouth of a crocodile awaited him. He had to shoot the lion and the crocodile before he got to his supper.*

One day Fletcher wrote the truth, and in time received a sharp reprimand from Mrs. Fletcher. He had shot at a wort-hog, which we designate "pig," and missed, and the animal had charged him. Mrs. Fletcher replied that she believed the lion and crocodile escapades, but she refused to. credit the ferocity of a pig, of whose harmlessness she had knowledge.

Fletcher had named his horse "Taffy," but we

* There were no lions or crocodiles within fifty miles of Fletcher's camp. 
nominated him by that nickname. "Taffy" was a very amusing "yarner" on horse-guard, and, perhaps, he inherited his mendacious proclivities from a Welsh bard ancestor, and with the tenacity of his race he is still in Rhodesia.

Others arrived to join-all picked men. Mr. Rhodes insisted on careful selection, and Young South Africa responded to the call from all parts, and so did Old England's sons.

Mrs. Nicholson and the Marais family had been busy making Boer biscuits and biltong, and the day arrived when our contingent set out-not the way we had expected to go. Our primary intention was to take the old hunter's road from Petersberg via Totsani, and join the main column at the Shashi River. This was countermanded, and we were instructed to go south to Mafeking. We passed over the plains of Zontspannesberg, reminiscent of the great fight of Piet Retief and Umgulikatsi's men, and also of encounter and massacre from Dingaan's blood-thirsty hordes.

We took waggons loaded with provisions, and also Boer meal for sale to the Chartered Company. Alfred Toomes followed in our wake with waggon-loads of Boer meal, to be disposed of at Mafeking, where, on account of the expedition, there was a demand for meal. He certainly would have been selected as a border-hunter. An Irishman, who had married and settled amongst the Zontspannesberg Boers, and who began life here 
as tutor to the children of Paulus Johannus Stephanus Kruger, the President of the Transvaal. We passed on the outskirts of Rustenberg, where Mr. Kruger had resided before he was called to Pretoria as President. One old Voortrekker on the Woodbush Mountains, Immilman, known as "O Pennetje," had related to me of the early days of Zontspannesberg when lions were plentiful, and he and Kruger had helped to drive back the king of beasts. He admired his President, but reminded me that Mr. Kruger had left Zontspannesberg and returned to Rustenberg, he had never gone back a step, his motto was "Voerwaarts" - a fine old Dutch pioneer.

On the outskirts of Rustenberg, Borcas, whose father was editor of a Potchestroom newspaper, joined us. He had gone through the siege of Potchestroom, in the war of 1881, which was so ably defended by Colonel Winslow. Van Eyck, who brought a long lean bay for sale to Nicholson. A few nights later this horse gave me a display of his footwork. I was going off horse-guard and counting with Pattinson, who was to relieve me, when he let out and sent me flying down the hill. Pattinson ran to me in alarm for my bones. I was quite all right through having been too close to him to get the kick, it was more of a shove. Well for me, as he had planted both hoofs in my stomach.

In the Groote Marico District we picked up 
Bob Jameson. Bob was an elder brother to Dr. Jameson, and had travelled considerably. Alick Halkett and I consulted the oracle about Mashonaland and Matebeleland with all the burning zeal of young pioneers. He gave us little information, commended our spirit, philosophised on disappointment and expectation. We voted him " prosy," and reminded him that even Socrates had to swallow a cup of hemlock on account of everlasting discourse. Alick suggested "priming" him up. We did. He became more genial, less communicative, and asked us to wave the flies off his head whilst he went to sleep.

We had come over the Oliphant's Trek from Rustenberg into the Marico district. This beautiful country was the theatre of war later, and saw much counter-movement.

Oliphant's Nek would be held by the British at one time and by the Boers at another. I was here at the time when Australians got out of an awkward hole, and were led to safety by a Colonial young lady. She had seen the whole movement from a neighbouring farm-house. The Australians were at the mercy of a deadly cross-fire and manfully fought on. Riding into the hail of bullets at a hand gallop, she swiftly sought the officer commanding, explained the position and led them out. We, Rhodesians and Australians, cheered her that night on Oliphant's Nek.

Honour to our Joan of Arc! Hats off, Aus- 
tralia! In justice to the Boers it must be recorded that they allowed her to ride home unmolested. Her father was a neutral, she a heroine acting on the instincts of humanity. My excuse for recalling this now is that in the list of pioneers you will find "killed in Western Transvaal." I have purposely brought in Australia because of her response to arms when the Old Country needed her sons. 


\section{Chapter III.}

Boer Tautas-Meeting the Johannesburg contingent-"Salted" horses-Mafeking-Rhodes-Recollections of Mafekingequipment.

Our contingent was-at this period-passing through the beautiful Marico district, rich in verdure, pasture and orange groves. We were buying oranges, excellent home-made bread, peach brandy, peaches, oat sheaves for our horses, at wonderfully cheap rates. A luxury for us coming from the far Transvaal Northern frontier-a remarkably fine country this.

The Boer Tautus tried to dissuade us from the expedition, as they predicted that we would be cut up to a man by the Matabele.

One old lady wept as she bade me "good-bye" with a "laste zein."

They were right in their estimation of the Matabele, they were wrong in judging Lobengula's control, but they did not know that the despot was a pensioner to the Chartered Company, and was receiving $\$ 100$ a month from them, any more than the people of England knew in the seventeenth century that Charles II. was subsidised by Louis XIV.

Between Zeerust and Mafeking we came upon 
the Johannesburg contingent, Lieutenant Mandy in command. My old friend, Louis Vintcent, was among them: the well-known "Villager" Captain and dashing three-quarter. A big, fair, rosy young man, with a happy laugh and cheerful smile.

"Monty" Bowden, England's fine amateur cricketer, had resided sometime in Johannesburg and thrown in his lot with us. Tall, handsome, dark and charming, "Monty" was a fine type of England's best. His wicket-keeping was a revelation to South Africans, and his late cut, over the off-stump, crisp as a blown kiss as he wafted the ball away with a flick to boundary - the game of a blown kiss knows no limit once caught on the wave.

Amongst the Johannesburg contingent was Wimble, one of the best bats of the Wanderers. Darling, an Irishman, who was a "broth of a boy," a medical man and a great lover of dogs. His black and white spaniel went with him everywhere. Young Mandy, nephew of Lieutenant Mandy. Corderoy, who was made a corporal, and the worry of whose life was the keeping of a "roster." Arthur Eyre, a typical son of Erin; tall, dreamy-eyed, dark-haired, and quizzically handsome. He brought with him several fine greyhounds. He had their repose, their lean, clean limbs, their easy action, but his eyes were the Irish ones put in with the smutty fingers. 
Schermbrucker, a son of Col. Schermbrucker, of the German Legion, now one of Rhodes' ministers.

The Johannesburg contingent challenged us to cricket and gave us a tremendous drubbing, due, chiefly, to the savage relish they took in my bowling, and the unmerciful manner in which they punished it. Wimble and Bowden were the chief offenders-to me-both played a splendid innings. We contested this match in the neighbourhood of Otta's Hoek, and in the vicinity are the Malmani goldfields. There is good gold here, but water is so plentiful that claims are continuously swamped, and the labour in pumping won't pay the individual miner. There is a subterranean lake of extreme beauty and mystery, with stalactite eerie columns hanging from the roof. The Boers call it Wondergat.

Nicholson had completed his purchase of "salted" horses, and in the Marico District he was successful in procuring a "salted" stallion, Meers was his name. Meers was a red bay, with a blaze and white-socked hind legs. He was wellribbed and round-barrelled, with a fine action. It transpired that Messrs. Johnson, Heaney and Borrow had the contract for the organization of the Pioneers-for which Mr. Rhodes paid down $£ 80,000$ for equipment-and that they were particularly anxious to get a horse like Meers for breeding purposes in Mashonaland. In these 
parts of South Africa, the Transvaal, Bechuanaland, Khama's Country, Matabeleland and Mashonaland horse-sickness was rife in the rainy season-which is in the summer. Horse-sickness was of two kinds: "dinne-paarde" and "dikkop " sichte. A horse to be properly "salted," i.e., inured from disease, had to have had "dikkop." The fact of a horse having "dinnepaarde" sichte was not sufficient to guarantee him, for " dik-kop" was the more deadly disease, and a recovery from "dinne-paarde" sickness did not mean that he would not succumb to "dikkop," any more than the fact that a man who had successfully recovered from typhoid fever would be immune from the ravages of malaria. A horse therefore that had become "salted" easily doubled his commercial value. Horsesickness slowed his paces and spoilt his coat, but a live donkey is better than a dead racer, so that a crock was worth fifty pounds, and a good horse "salted" anything from sixty to a hundred pounds. When a man sold you a "salted" horse he gave you a guarantee for twelve months against horse-sickness. Should the horse die of horse-sickness during that time, you gave a sworn declaration before a J.P., attested by two witnesses. The J.P. affirms the declaration and states that he had seen the horse and was of opinion the horse died of horse-sickness. In cases of certified death by horse-sickness you re- 
ceived your money back in full-provided you had not to sue for it. It is obvious that in purchasing one had better do so from a man of standing, for it will readily be seen there are plenty of opportunities for swindling. As a matter of fact there has been more hard swearing and persistent mendacity over "salted" horses than "salted" mines in South Africa-that's saying a great deal, for the mine average is a notorious one. There are men of all nations at the practice : taking a chance of horses escaping disease during the stipulated twelve months, or taking a change when sworn declarations swarmed like locusts to the door. Those are the peccadilloes of human nature. What of the horse? Has nothing been done for him? Many have endeavoured to solve this horse malady. It has engaged the attention of Professor Koch. Dissection shows a complication in the whole internal anatomy, but nothing has been discovered to combat the evil or trace the origin.

* * * * * *

We found Mafeking in a bustle and the place was fast growing into what Rhodes had described it as, " the Key to the North." Other contingents had been equipped and journeyed on to Macloutsi, which was our base. To these parts Rhodes had come when a young rich diamond digger with Sir Charles Warren, and had gained that leader's 
admiration for the skill he displayed in the conduct of affairs of that expedition. Mr. Rhodes was now the Cape Premier. I had heard him speak in the Cape House of Parliament. He was not impressive but convincing. He handled statistics easily, but he spoke too fast and the tone was inaudible at times. He had an earnestness and ardour that carried far, and at that time was eagerly listened to. He was fond of the name "Hinterland," and the enthusiasm he had fired had spread far and wide in the British Empire, and now his dream as a young successful diamond digger was a realism in part, for there was much to be done before that big dream could be defined as accomplished. He spared neither time nor money over the Hinterland-Mashonaland and Matabeleland-called later Rhodesia. A few years later I saw him often, when as Premier of the Cape Colony he was wont to stroll from the Houses of Parliament through the St. George's Cathedral grounds to the hotel in New Street-now Victoria Street-where he always lunched. I saw him again in 1896 in the Matoppo Valley.

There was a good story going round the camp, over which we all laughed at that time. $\mathrm{Mr}$. Rhodes was seated on the box of his waggon when a man passed him loaded with a very fine paauw. -bustard-which he had shot. Rhodes offered him a sovereign for it. The man refused the 
tender, but stipulated that he could have it for a bottle of whisky. Rhodesia's Chief did not concede to this, and the man's adieu was, "All-right, Mr. Rhodes, no whisky; no paauw" An independent spirit that no one appreciated more than Rhodes himself.

Not long after this he went into the Matoppo mountains and settled peace with the Matabele chiefs. About eighteen months after this I had a long and pleasant chat with him in his study at Groote Schuur. Jack Grimmer-one of our Pioneers-was his secretary then. Mr. Rhodes entered keenly into the conversation and asked for names as Jack and I spoke merrily en camaraderie. At that time Groote Schuur had recently been burnt down, and Mr. Rhodes was making shift in the few rooms that had escaped destruction. I saw his funeral a few years later as it passed down Adderley Street. The people of England's mighty Empire know that his tomb is on the plateau of the Matoppo mountains. We reverence it as the Last Rest of Rhodesia's Chief. And Mafeking-the place he made-I have seen busy several times, but at no time so active as when we raised the siege during the Great BoerWar and relieved our thirst with siege whisky obtainable at the price of three shillings a dram from the local hotels. You were admitted singly and the door closed on you and locked. You gazed at the holes in the roof and the holes in the wall and 
commented on it. Overcome with grief at the wanton destruction you put 3s. on the counter and you were supplied with a whisky. I always looked upon it as a contribution to the building fund. The red-painters found the price a prohibitive one for amusement. No flat sympathy was encouraged, for teetotallers got no admittance to these private views. We were able, however, to purchase soap and candles and send them to friends in Buluwayo, which all this time had been in an infinitely worse condition than Mafeking, for with Mafeking surrounded Buluwayo was isolated.

To return to Mafeking in 1890 and its relations to the Pioneer Force. It was the depôt. In the Bechuanaland Border Police camp we signed our attestation papers and passed on for equipment. Each of us was served with a brown cord tunic, grey cord riding-breeches, yellow leather leggings, a brown slouch hat, two grey flannel shirts, two pairs of grey woollen socks, a woollen jersey, a pair of ammunition boots, two brown woollen blankets and a water-proof sheet, a pair of heavy spurs, a suit of slacks, a havresack, a water-bottle, a very serviceable "house-wife," filled with thread, cotton and needles of all sizes, a blue-cloth cavalry overcoat-of excellent quality. We were armed with the Martini-Henry rifle, a six-chambered Webley revolver and a hand-axe-the pioneer's tool and deadly weapon. 
The revolver-case and revolver cartridges and axe-case were slung on a broad brown leather belt. The leather was strong and of good quality. A bandolier with a hundred rounds of ammunition was slung slantwise over the shoulder. These bandoliers were not a success. They were made without covers and after riding some miles the ammunition would gradually work out. On the march we remedied this nuisance by making covers of canvas. Those who did not do so were constantly shedding ammunition. The best type of bandolier was the pattern served to the B.S.A. Police, every five cartridge compartment had its separate flap and a metal stud to close down on. The bandolier excepted the equipment was excellent. As a matter of fact I saw considerable service later in mounted corps, but never were the rations or equipment of the Pioneers equalled. A bridle with a Pelham bit and semi-military saddle of good type. The horns were not too long and took your patrol tin and case nicely. The saddle-cloth was too thick for the hot climate. I did not use mine, but substituted a cotton blanket, which was cooler for the horse's back. I made a good pair of slippers out of that saddlecloth later, with a jackal-skin for uppers. 


\section{Chapter IV.}

Journey to Base Camp - Spreckley - Molopolole - Charlie

Masters-The camp at Macloutsi-Lobengula.

Passing up Bechuanaland we kept along the Crocodile and procured plenty of guinea-fowl for the pot. It is a dry country, but the river that fringes it, and is the boundary between this and the Transvaal, is very fine with giant trees of shady foliage growing profusely on its banks. Our horses have come a long way from the Transvaal and are in good condition, for we do not push them to fatigue, give them plenty of corn and grooming on the way, besides daily grazing. The drove of horses keep us occupied, and in this we have the advantage of other Pioneers who have passed up by the tedious ox-waggon and springless carts. We had all picked our mounts and Nicholson had promised to see if we could retain them. Disappointment awaits most of us, for there is a demand for these "salted" horses, and the officers have first pick. Among the horses is a chestnut with high withers and a sloping back. I had named him "kameel," the Boer name for giraffe. He was shockingly out of condition when we bought him, but he caught my eye and I had given him many an extra feed. He 
had a fine turn of speed-although salted-and we were both hard hit when the sergeant-major of "A" Troop, an Irishman, Mahon by name, chose him as his mount.

We were still running parallel to the Crocodile when a mounted man overtook us one night. I was lying in my blankets, reading by candle-light, and heard him asking Nicholson who he had with him. On the mention of my name he asked: "Where is he?"

"Here," I answered.

It was Jack Spreckley. Soon I had a meal for him and a cigar. I had brought a box with me, knowing that it would be a long time before cigars would be obtainable again-if ever. He got his blankets from his horse and made his "doss" next to me. Jack Spreckley had played full-back for a Kimberley team that came down to Capetown, and I had played against him for the Hamiltons. I had not heard of him since. It transpired that he had been to Shoshong with Johnson, Heaney \& Borrow, concession hunting. All four of them had seen service in the Bechuanaland Border Police, and on taking their discharge had drifted northwards and gained an audience of King Khama. He was riding ahead to Macloutsi, as he had been nominated P.M.S. to the Pioneer Regiment. Spreckley always was a practical joker and there are many stories of his pranks. Under the waggon that night 
smoking cigars with me he told me of the Pioneers ahead. Frank Johnson was Major to the Regiment, Heaney Captain of "A" Troop, and Borrow Lieutenant of "B" Troop. The Pioneers could not have had a better P.M.S. and he was good to all of us. Every Rhodesian remembers Jack, but for the benefit of other readers I must mention here that he became manager of Willoughby's Consolidated in Buluwayo, a colonel in the second Matabele War, and as Colonel Spreckley, in command of " $C$ " Squadron of the Rhodesia Regiment, he was shot at Harman's Kraal in the Great Boer War.

We reach Molapolole. It is a very large stadt on an elevated kopje. The natives are amicable and trade readily. Many want to sell us pythons, and these natives eat them and regard them as succulent. Some of our men buy the skins of pythons and others of puff-adders, which they wear as hat-bands. Charlie Masters joined us: here. He had come down from Lake Ngami, had been in the Bechuanaland Border Police, and was a credit to that corps. A handy quiet man, with all the knowledge and craft that go to make a good veldt man and ideal trooper.

This country is healthy enough but arid. Water has to be carried from one trek to another in barrels. Horsemen would do well by carrying water in the same way as the Australian does. across their desert country, in canvas bags: 
circling the horse's neck. Canvas water-bags are carried in Bechuanaland attached to the saddle behind the stirrup-leather where the trooper carries his nose-bag. The Australian method is the wisest, for you can carry plenty of water for man and beast in their way.

We drove our horses day by day on the track northwards, came to a Mapani forest, and in a glade we struck-so it seemed-the home of the Liliputians, for the tents in soldierly array were the sweetest little midgets imaginable. This was Macloutsi; and the baby tent was a wise method of dispensing with weight and yet giving shelter. They were three feet high and had sufficient room for two to sleep in.

We had reached Macloutsi and we had come a very long way round. If an isosceles triangle were to be drawn, with Mafeking as the apex, the two sides of the triangle being described from Mafeking to Petersberg and Mafeking to Macloutsi, and the base line from Petersberg to Macloutsi, then we had travelled two sides of an isosceles triangle to get to our base, and it really was an asinine way of tackling the proposition. They were our orders, however, and we had to obey. I have previously pointed out that Lieut. Nicholson wanted to come through Zontspannesberg and cross the Crocodile via an old hunter's track. We had got here, that is the main point. The camp was formed in a square. The stores 
were the first thing that you observed coming from the road. Piles of Boer-meal, sacks, flourbags, sugar bages and boxes of biscuits and ammunition. Mealie-bags, tobacco-bags-we were served with a very good Boer tobacco as a ration. In no other corps that I know of has tobacco been issued, but it is purchasable at a reasonable rate, where convoys can reach the troops. Amongst these miniature hills of commodities Jack Spreckley could be seen daily, with fatigue parties at his disposal for "baghumping " or "ammunition-slinging," and it was here that I made the acquaintance of Bob McClennand, an Eastern Province Colonial, tall and brown-bearded, freckled-faced, slow of movement: he could pick up a couple of ammunition boxes-filled with cartridges-as easily as the ordinary man handled dumb-bells. It was Spreckley that drew my attention to Bob's muscular display, and I watched him in sheer wonderment. He was a giant, easily reaching six-foot-six. A feature in his build was a wonderful length of thigh, the legs from the knee to the feet being short in proportion. He was a good-natured man, as giants generally are, and spoke with a stutter that was laborious.

Behind the stores was " $\mathrm{C}$ " Troop-the Artillery-their tents, guns and horse lines.

"A" Troop formed the left of the square with their tents and horse lines. 
" B" Troop the right and below, nearest the river; the officers' quarters formed the line opposite to the artillery and stores.

The transport-department occupied a camp to the rear of " $B$ " Troop lines.

These Pioneers had come up from Kimberley, the terminus of the Cape Railway, the starting point of the expedition: the erstwhile home of the founder and organiser, Rhodes, of this work that we were undertaking, which led to a vast extension to the British Dominions beyond the seas. This expedition proved conclusively that the honour of a native king pledged in his contract was of as high a standard as the integrity of a lofty-minded man of our civilization, for his "there is wall built round the word of a chief " was equal to our "my word is my bond." It also proved again that concession-hunters, concessionaires and others of that ilk are in a class by themselves, where integrity is walled out. Lobengula refused the bait and did not swallow up the "bon-bouche" that was sent him. The Pioneers were the hors-d'œuvres to whet his appetite, and as he declined the dainty there was no occasion for Great Britain to revenge us; but an integrity such as Lobengula's was incompatible with the workings of a charter, which had no patience for Fabian policies and being a heathen who had no right to the high virtues, he was " eaten up." 
If "Hinterland" has become dear to us because it was a favourite term of Rhodes', the epitaph of Lobengula is writ in brass, "there is a wall built round the word of a chief." You know the story of the burglar who stole the Abbés gold candlestick and the good man told him to go home. That is the position of the Pioneers to Lobengula. The feeling of having been spared by a man who had it in his power to destroy produces a sympathy that is human; and a man that can keep his word-no matter what he does otherwise-is a man that deserves admiration of us.

Picture again that we were at the stake, with the faggots around us, and Lobengula declined to kindle the flame, and that flame a horde of stabbing Matabele, then pardon the Pioneers for their tacit veneration of the old savage. You people who watched the game, we, Pioneers in the arena, are on a different footing. You may applaud Rhodes, so do we, but Lobengula, the lion that would not devour us, is our "uncanonised" saint. We are the live stock that did not pass through the sausage machine. Loben was the butcher-who did not slaughter us. 


\section{Chapter V.}

Grimmer - Coryndon - other Pioneers-Major Johnson Captain Heany-Borrow, Colquhoun, Judd, BerkeleyShaugani heroes-warriors knowing how to die.

IT was a long way that this southern contingent had come via Taungs, Vryburg and Mafeking. They had camped on the Crocodile and named the place Cecil Camp, in honour of Cecil Rhodes. At this place they had been drilled constantly and had pushed on to Grobelaars Drift, on the Macloutsi River, where we joined them and were drafted into the troops. I went to "A" TroopHeaney's-and was not parted from "Kameel" altogether.

There was plenty of work, for we were being drilled morning, noon and night, as Major Johnson was determined to have an efficient body of men, and night-alarms seemed to be a mania with him. We must have had a fortnight of this when the last few to join us arrived. They were all Kimberley boys and had been doing duty at Palapye. I knew most of them already and was pleased to meet again Jack Grimmer, Bob Coryndon, Roger Adcock, Christison, MacRobert, Ehlert and Stanford. 
Jack Grimmer was a good-looking, upright lad, subtle of humour, beloved of Rhodes, and dear to many of us. He became Rhodes' secretary and did not long survive him.

Bob Coryndon had been to school at Brooke's, Claremont, and as I had also been a "Brookite" we were old chums. A straight-featured, squareshouldered lad, of quiet determination and amiable disposition. He entered the Civil Service of Mashonaland, and when Rhodes was seeking an administrator for Barotzeland Bob suggested himself, and Rhodes never made a better choice.

Roger Adcock, a pleasant young giant, became one of our syndicate. Was Captain of Intelligence to Lord Methuen in the Great Boer War, and is in business at Johannesburg.

The Capetown Highlanders would remember Christison, who had been their adjutant in former days.

Patrick Campbell, a good-looking quiet man, ready to play his part on the stage of events before us. He served the Chartered Company as a Civil Servant, and he became an actor in the Great Boer War, and when the curtain was rung down and the piece had had its run, it was found that at the "cannons' mouth" he had given his life for the grim play of Empire. The clever actress, his wife, has long been adored for her talent of impersonation on the British stage. Christopherson, Taylor and Featherstonehaugh 
were with this little party that rode to join our ranks on this day.

Alick Halkett had found Fred Brand, son of Sir John Brand, late President of the Orange Free State. They had been contemporaries at the Diocesan College. Leo Neumayer was another friend of his that he discovered in the artillery troop.

It would be wearisome to the reader to go through the names of all the Pioneers, it will be sufficient to introduce those who come on to the stage-so to say-when an incident demands their appearance.

It is time though to look at our officers : Major Frank Johnson, a short, thick-set, furtive-eyed, dark man, with the lungs of the Bull of Bashan, and the knack of handling men and hustling things.

Captain Heaney, "A" Troop, a red-headed and red-bearded Virginian, quiet of demeanour and deep of thought. This was the Major Heaney who was sent to stop Dr. Jameson later-I refer to the Raid-but went with him when nothing would stop him.

Lieutenant Borrow, "B" Troop, young, athletic, tall and dark. He had a fine appearance and carried it with a charming manner. $\mathrm{He}$ gained the hearts of all of us, and we were wont to say of the firm of Johnson, Heaney \& Borrow, that Heaney did the thinking, Johnson the talking 
and Borrow the work. He took an interest in all of us and joined in our sport. He acquired vast interests in Rhodesia and was never away from it long. High-principled, fearless, tenacious, that pertinacity and persistency that led them to rush to their end at Shanghani. I say their end; because there are sunny-tempered, bright-eyed, straight-limbed young men in this camp who fell with him: Colquhoun, Judd, Berkeley, firing until the last cartridge was spent, with thousands of Matabele warriors steadily closing in, determined to save Lobengula, their king, from these white intrepid warriors; smarting with the recent defeats of their crack regiments by these men and their comrades, they came on, steadily narrowing the circle, and as the sunlight waned in that gloomy Shanghani forest and the Matabele knew the last cartridge was spent, they hurled themselves forward with their defiant war-cry, setting the bush-buck running in trepidation, but not these British warriors; for they answered the terrible war-cry with three ringing cheers, stood their ground like the warriors they were, and, as the hills echoed and re-echoed those hurrahs the deadly stabbing assegais were plunged and re-plunged into their fast-expiring frames, whilst the slayers chanted over their grim work that they did this for the love of their fathers, who were warriors, for the Son of the Black Calf, Lobengula, the Mighty One, All-conquerable! What 
derisive laugh is that that breaks the night? Ye Matabele, you may well start at the screech of the forest owl, you may well throw the burning faggot at the laughing hyena, for your boasting is mocked by reason. Those dead heroes, journeying to Valhalla, the meeting-place of warriors, were unconquerable even in death, and the British cheers that died on their lips lived again at the christening of Occupation. See how the mighty have fallen, your obese monarch orders the trek to continue, those cheers have disconcerted him. Poor ill-fated chieftain he rides to his doom, for these exertions are beyond the Falstaffian frame. Sorry for him-yes. He was not antagonistic to the white man. For the moment we are paying tribute to warriors. We are not discussing the wisdom of the pursuit, we are chronicling the deeds of warriors. The tradition of the British race was maintained and upheld here-as it has been done before-as we hope it will be maintained by our children and children's children. Here is the tomb of heroes. I have given you these shadows because the events have proved the quality of the comrades who are at this time laughing in the camp, careless of Destiny and fearless of the Matabele. The Pioneers were men who went out to make history for the Old Country, and the lives given are but the milestones of the great British Empire. 


\section{Chapter VI.}

Pioneer Officers-R.S.M. King-Lord Methuen-"Keenness" of the men-Diseases of cattle.

Continuing the introduction of the officers we come to Captain Roach, in command of " $\mathrm{C}$ " Troop. A tall, rough-looking man, a splendid artillerist. He had worked for De Beers and subsequently saw much service in the development of the Cape-to-Cairo route and in the Great Boer War.

Mr. Adair Campbell was Lieutenant to " $A$ " Squadron. A fair man with beautifully-tattoed fore-arms.

Captain Hoste-formerly of the mercantile marine service-was a long-legged top-heavy man and well-liked. A sailor on horseback he looked all through the expedition. He had a brother in the ranks of " B" Troop.

Mr. Briscoe, of H.M. Navy, was Lieutenant of "C" Squadron. A quiet little man, like most naval men; "all-there" when wanted. He was. also a general favourite.

The two Burnetis, Ted and George, were in charge of the transport. Ted ranked as Captain and George as Lieutenant. I have already mentioned Lieutenants Mandy and Nicholson. 
Our medical department was represented by Drs. Tabito, Brett and Lichfield. We will become acquainted with them later.

Canon Balfour and Rev. Mr. Surridge ministered to our Protestants and Father Hartman to our Catholics. Father Hartman, a priest of the Jesuit order, knew a great deal of Matsbeleland, more of the Mashona languages-there were many-than Selous himself, and the good man was busy working at a Mashona vocabulary, but the strongest hand in vocabulary was Regimental Sergeant-Major King, only it was not Mashona!

Up to now Beal had been our R.S.M., but he had received his commission-he was the Lieut.Col. Beal in the Mashonaland Rebellion-it had been celebrated at the officers' mess with considerable gusto and we awaited The King. I emphasise it because his arrival was well mooted in camp, and we were told to look out for squalls. He had been the Regimental of the Bechuanaland Border Police, and had a reputation so strong that our officers thought, if necessary, he would make a dragoon of Lobengula himself. He rode into camp alone. He threw his critical eye over the camp as he rode down the lines. A tall, lean, high-nosed dragoon, spick and span both he and his horse; but there was a distinct theatrical air in his posture. It took me a long time to have the temerity to engage him in conversation, for he 
was awe-inspiring, but in a campaign occasions come when even the austere thaw, and it was later that he condescended to tell me-a young trooper - that he would have loved to play Hamlet to a London audience. I learnt that he was passionately fond of amateur theatricals. I gazed again at the military gauntlets and the trick he had with them that fascinated me on the day of his arrival. Stript of those gauntlets he would condescend to social amenities, but they had to be theatrical. After disbandment at Fort Salisbury we scattered north, south, east and west prospecting for gold. I met King North, on one occasion, and he assured me that he would build a theatre in Salisbury, when he had sold the claims he had pegged. We were all sanguine in those days. I met him west, on another occasion, and up there in Mashonaland news had reached us of America's Exhibition, and, of course, we were all going to see it. "Chicago 93" was his farewell to me. I never saw him again, but know that neither of us got there-'93 saw the First Matabele War.

Dr. Jameson came into camp about this time, and not long after we were put through an ordeal that meant much to our prestige. Lord Methuen had arrived to inspect us, and if he had been dissatisfied with us we would have had to delay the expedition. We had days of manouvring and volley-firing, and independent firing at targets that had been placed in the bush. We did not 
know where these targets were, but came on them as you might an ambush, and received the order to dismount and open fire, either volley-firing or independent firing. We rode to the support of one another, and we retired fighting a rear-guard action. Most of the targets were riddled to fragments. Lord Methuen complimented us that night, when we were drawn up to receive his words of commendation, and he particularly commented on the excellent shooting. He said that we could go anywhere and give a good account of ourselves-or words to that effect-and the younger ones flushed with pride at the praise of the keen-visaged soldier, and the older ones blinked an eye; for there never was a corps yet that hadn't been the finest in the world. Some of them had been there before. Years afterwards Lord Methuen met some of these men again and the name of Methuen and the mon are writ on the scroll of Empire.

Paddy O'Toole, V.C., was one of us. He got the Victoria Cross in the Zulu War at the same time as Sir William Beresford. Together they carried a wounded comrade to safety under a heavy fire. Paddy was a medium-sized, squarebuilt man, grey was already tinging his beard, smartly trimmed to a point, but he was hard as nails. A modest unassuming man, careless of dress, but his mare had the glossiest coat in the regiment, and she was a perfect animal, clean 
made, with dainty ears and fetlocks. A black mare with tan points. Meers grazed with our horses and he was always sweethearting with her. She carried Paddy through the expedition, did not get horse-sickness, and he never gave her a sore back. They were grit right through, the two of them. Paddy started a potato-farm within a few miles of Salisbury, and battled manfully against the grubs and insects which abound in the virgin soil of the country. The first year of our occupation was a record wet one, and potatoes simply rotted in the ground. I have watched Paddy, bare-footed, digging for traces of potatoes he had planted. He was bare-footed because the rains had been so heavy that his potato patch was a swamp and he would sink knee-deep as he dug. His potato-patch was his grave, for Paddy succumbed to malarial fever in 1891.

Lord Methuen clearly pointed out to us that we were facing many perils, and that amidst the hardships of pioneering whilst cutting a roadway through a strange land, we might be attacked by the Matabele, and that anyone who desired to withdraw from the expedition could do so now by communicating his intention to his commanding officer. We slept over it that night and only three men decided to go back. To the rest of us the Matabele, lions, elephants, gold, diamonds, the Victoria Falls were all inducements keenly desired to get in touch with, and we were zealous and anxious to proceed. 
At last the day arrived to set the expedition forward, and the Pioneers were breaking camp and the waggons loaded with a weight of 5,000 to $6,000 \mathrm{lbs}$. were on the move in long stretches of convoy, and disappointment awaited fourteen of us, of which I was one, because Lieutenant Mandy was left behind to round up stray cattle, and he was allowed to choose fourteen men to assist him in this work.

None of us liked the idea of being left behind, but as Mandy maintained that the time would soon pass, and we would catch the column again at the Shashi River; for they would make a fort, wait there to be relieved by the B.S.A. Police.

The plan of campaign pursued was that the Pioneers should open the way to a given point, the B.S.A. Police to follow in our rear, hold the position, fortify it, and patrol the country.

The B.S.A. Police were being rapidly organised and had their own camp at Macloutsi, twenty-five miles distant from the Pioneer camp.

The Pioneers were to receive seven-and-sixpence a day, the rights of a farm, and fifteen gold claims. The Police were engaged at the rate of five shillings a day and had rights granted to each troop. With reference to the gold claims, as anybody coming into the Mashona country was entitled to ten claims on the payment of one shilling on those terms in the Gold Law, the Police were able to procure prospectors' licenses 
and peg claims. The Police formed syndicates and appointed prospectors to them, and the " $B$ " Troop Syndicate, especially later, held many promising claims. That is relative to subsequent events, that is to say, the establishing themselves in the country, for the present this corps was being organised as a permanent body. The Pioneers were to be disbanded on reaching their destination, Mount Hampden. Mount Hampden was the goal to which Selous was to guide us.

Few things are so "hump-inspiring" as to be left on the scene of desolation. Yesterday there had stood a fine theatre here and the actors had been busy rehearsing their parts in the grand piece of "Occupation," and the fire of enthusiasm had swept them forward, surging onward, whilst fourteen of us were destined to study the devastation, and reflect that destruction was ever hovering in the Camps of Life. Death was already stalking amongst us, but was taking its toll amongst the patient uncomplaining animals. Horses and oxen were daily being dragged away. to receive their obsequies from the African funereal minister-the aasvogel. We were the mutes with this distinction, that it is not permissible to the training of a pioneer to howl, and he takes his "dole" meted to him with dumb patience, the example ever before him, as an object lesson, is the horse and the ox.

Horse-sickness is the scourge amongst horses 
and lung-sickness the ravager amongst bullocks. There are many maladies that both beasts of burden have to submit to, but these mostly can be combated by the intelligence of man. On the signs of lung-sickness amongst cattle the diseased bullock is isolated and shot and the carcase burnt. The remainder of the cattle are inoculated in the tail with parts of the diseased lung, saved for that purpose from your infected bullock, which presumably has been destroyed. The Boers inoculate in two ways-always in the tail. One way is to cut an incision with a sharp knife and rub in a piece of lung, tying the bandage temporarily on the inoculated part. The other way is to smear string with the diseased lung and pass it under the skin in a place selected on the tail-generally twelve inches below the rump-by means of a sharp sail-needle. In most cases the irritant introduced is so severe that the tail drops off. Where it remains the tail has taken a decided distortion at the point where inoculation was introduced. A bullock surviving inoculation is known as "salted," and is worth double its original value. What is the cause of lung-sickness? It cannot be advanced as want of fresh air, for we were all getting plenty of that. No, it is the difference of air, the want of acclimatisation in the beast, for just as you draft men from all parts to form a regiment, so also your contractors are purchasing cattle from dealers who 
bring them from the different points of the compass. Lung-sickness, like pneumonia in mankind, is short, sharp and decisive, and the stronger the constitution the worse the fight. Lung-sickness will affect a whole district in a very short time if allowed to run riot. The chief cause of death amongst the bullocks was gall-sickness, which again is due to want of acclimatisation, for this is the result of grazing and poisonous matter introduced into the system from unsuitable grasses. One would think that the bullocks would have sufficient sense to choose their diet, for we are acquainted with horse sense, and know how fastidious the horse is in his drinking-water. Reverting to the bullock, the answer is that if he came through the country on his own initiative he would be more particular, but we inspan him to drag loads for miles and then turn him loose, hungry and tired, to find his own food. It may be, too, that the tired stomach loses the strength of disposing of injurious matter, which it would under normal conditions.

We had pitched our tents, each man a tent, in front of the place that had been occupied by the stores and on fresh ground to the right. We were near the road and easily in touch with the passerby. In this way we observed a waggon loaded with brandy and lime-juice draw up for outspan. The camp was fast becoming a pestilential centre with a circle of carcases which the aasvogels could 
no longer deal with. There were legions of these grim bald-headed birds-venerated by the Egyptians-too gorged to fly, they ran screeching to the bush as you approached. Wandering through the banqueting hall of a Roman lord in the times of their excessive luxury must have been similar to this-birds of prey rendered incapable by surfeit, and Nature and Evolution gave the aasvogel and the Roman his work amongst us.

The juice of the grape in moderation, judiciously pressed and applied for consumption, has ever been a friend, and its history was long before that of Rome. I approached Lieutenant Mandynot classically, that would have induced argument -from a medicinal point, and explained that without stimulant we would fall to enteric and never reach Mount Hampden. The wind supported my appeal, for it was wafting across the camp an odour of decayed horse and polluted ox that would have disturbed the olfactory organ of a lethargic python and driven the inquisitive nose of a crocodile below water. He bade me roll off from the waggon the smallest cask of brandy and the largest of lime-juice. The aromatic atmosphere must have impaired my vision, for I reversed the order and brought into camp the largest cask of brandy and the smallest of lime-juice. Lieut. Mandy allowed the matter to stand at that, for the waggon had trekked on to join the main column, but chose me pretty constantly to take the 
numbers of the dead horses. They were branded on the hoof. It was his method of punishment. He took his rations with us and sat at the head of our table, a few planks knocked together, supported by empty biscuit boxes. We had our camp fire near, and at night he was wont to tell us of the gold that could be seen in the Kraal walls of Buluwayo, and of the fruit that grew in the country that only awaited picking. We, blessed young innocents, believed it all. Lieutenant Mandy had fought for the Vatican Army against Garibaldi and delighted us with glimpses of Italy. The daily scouring of the veldt for lost cattle was gladly looked forward to as a means of escape from the unhealthy, unsavoury camp, and we brought in many horses and bullocks. These were chiefly found on the other side of the Macloutsi where the bush was thick and the grass sweet. These were sent on with passing waggons to Shashi, which was now the main camp. The Macloutsi was a typical South African river, dry sand with stretches of water, few and far between, along the route of the river-beds. The soil gave diamondiferous indications and garnets could be picked up plentifully in the river-beds. The Kimberley boys when on horse-guard here must have been reminded of Griqualand West, for it was customary to sit in the river-bed and gather these pretty stones, whilst watching the horses which congregated on the banks to browse the young 


\section{PIONEERS OF MASHONALAND. 47}

bamboo shoots growing in profusion. Close by was Grobelaar's drift where-it is alleged-he was murdered by Khama's natives, and led to the British Government allowing Mrs. Grobelaar a pension as compensation-that was some time previous to this expedition. 


\section{Chapter VII.}

Grobelaar-Khama-historic trading.

Khama, king of the Bangmangwato, had established a native cavalry, and for this purpose he required salted horses. Grobelaar had sold Khama many horses of which some had died. He was overtaken on the Macloutsi, shot in the foot by a Bangmangwato native and died of bloodpoisoning. As Grobelaar was a burgher of the Transvaal there was much indignation over the matter, and-naturally enough-it was alleged that the chief in his disappointment had given expression to the desire of getting his own back. One recalls the : "Who will rid me of this priest?" The massacre of Archbishop à Beckett by knights ready for adventure, unscrupulous of bloodshed, seizing opportunity for self-aggrandisement by interpreting a king's wish. The simile is not exactly a happy one, there is martyrdom certainly in the case of the archbishop, and if it was a sacrilege to kill a priest at office in Norman days it was bad business to kill a Boer in South Africa in these days. The conduct of the knights and the natives was to curry royal favour, and the regret was apparent in both sovereigns, and the 
British public paid for the one in pilgrimages and masses and by a pension in the other. The recalling an incident so far back in English history brings a white race to the recollection that the process of civilization in his case was gradual and extended over centuries; it is therefore only; fair in dealing with black races to keep the laws of Evolution before you when you are legislating for him. It would be hypocritical to advance it as a policy at a time when map-painting was in the curriculum of everybody's education. The Chartered Company did not get their grant for the purpose of the study of the ethnology of the country or advise it in Economics.

Subsequent events lead one to suppose that with a medical man as administrator the policy adopted was on the lines of infantile growth. The birth was the Pioneer expedition and the christening at Fort Salisbury and the cutting of its teeth at Massikessi. At the age of three the Charter baby walked into Matabeleland, scared the possessors with its rattle of maxims, and secured all the toys it could lay its hands on. It went through scarlet-fever in 1896, after its medical adviser had neglected it to specialise on the bacteria peculiar to the gold-bug of the Transvaal. Meanwhile the scarlet-fever over-ran Matabeleland and infected Mashonaland, until the epidemic after severe ravage exhausted itself. The neglect of the Charter baby, when in a high 
temperature, has stunted its growth, and at the age of twenty-five it is not yet able to stand on its own feet. Space will not permit me to go into the militarism of Lobengula and the raids of his impis, or to enlarge on the policy of the Charter Company.

I drew attention to the death of a great churchman to lead you on to the life work of another in our own times the Reverend Mr. Moffat, the adviser of King Kahma. You find Khama, a monogamist, married according to the rites of Christian religion, and its ceremony even to the detail of the bridal veil and orange-blossoms. That is a very big achievement to get a potentate to give up his right of many wives. It is an ancient custom and means power. Recall for a moment that most of King Solomon's marriages were political alliances. A Kaffir king and an eastern potentate know the same diplomatic move. Lobengula married a sister of Gungungana-also a daughter of the Swazi king. Kent owes its conversion to the marriage of a Saxon king to a Christian queen, and the subsequent baptism of their king was good enough for the men of Kent to adopt Christianity, so likewise the Bangmangwato race are a Christian people. Critics might point out that there is still a certain amount of heathenish superstition amongst them, but then it is fair to add that it exists amongst us to-day, and was very conspicuous in this country 
in the seventeenth century. Furthermore in giving examples of higher principles amongst savages than amongst black Christians, don't stop at the black, make it black and white, and the virtue of the heathen would be wholesome to many of us as well. And do not the heathen philosophers of bygone centuries to this day still guide us in attempts at good government of state and self ?

With regard to Khama's country you can travel the length and breadth of the land and hear the hymns beloved of this country. You can trade for food for yourself and horse anywhere at a stipulated price-which is reasonable. You are saved the haggling which you must go through with the heathen-to his detriment at first for the white man cannot resist getting something as near as possible for nothing. Later white men spoil the market by competition, and the native, made wise, asks exhorbitant value in return-to your detriment. Later on it will be seen that we caught the Mashona fowl with a handful of saltvalue one halfpenny. Still later somebody gave two shillings for a fowl and made the price. In Khama's country you can get a fowl anywhere for one shilling, a bottle of milk for sixpence. That is cheap, for the country is dry and pasture scarce, but as milk is a germ-carrier, and hygienic bottle-washing has not been taught it is wiser to use condensed milk, which is a luxury only for the man who travels slowly and can carry extra kit. 
Perhaps the best story of trading in South Africa is recorded by Mr. Theal in his history of South Africa. Overbeek, on his return journey from Batavia to Holland, conceived the idea that the Dutch East India Company wanted something more substantial than occupation for its rights over territory. The Hottentot chief of the neighbourhood of Kapstad was induced to accept presents to the value of $£ 9$ odd in blankets, beads and sundry tawdry goods, and sign his mark alloting the territory to the Dutch Charter Company. The repetition of history is proverbial and on this expedition we were to show that our English commercial instincts were quite as shrewd as the old Dutch pioneers in getting territory ceded at bed-rock price. 


\section{Chapter VIII.}

Livingstone and Moffat - Khama and Lobengula - Gordon Cumming.

The task of the Pioneers of 1890 could not possibly have been undertaken but for a previous work that had steadily gone on for the past fifty years. I allude to the missionaries and purpose to briefly note the fruits of their labour.

First let us look to Shoshong. Here came Robert Moffat and Livingstone. Glancing at the map the eye wanders north and settles on the Zambesi where the town of Livingstone stands, where natives still cherish the name of its founder and where to-day the Cook's traveller alights on his way to the Victoria Falls.

Moffat went to Matabeleland eventually, and his labours were taken up by others of the London Missionary Society, and at the time of the expedition of the Pioneers the work was carried on by the Rev. Mr. Helm and the Rev. Mr. Carnegie. The beautiful mission station at Hope Fountain, ten miles from Buluwayo, was the haven for the sick white man and many a fever-stricken body and storm-tossed soul received succour from the able missionary and his gentle wife. 
That Lobengula and Khama should be compared would be manifestly unfair. That the efforts of the missionaries with Lobengula should be contrasted with the conversion of Khama would be unjust, unless we look facts in the face.

Khama early came under the guidance of Robert Moffat and influence of Gordon Cumming. The teaching of the one missionary and the character of the hunter made their impression on a mind who accepted the Christian faith as a young man in opposition to his father and his people. The young Khama married a Christian native, and when the Matabele raided his father's country he set out at the head of the army and checked the invaders. Both the Matabele and the Bangmangwato praised the young prince for his courage, and the Bangmangwato cried out that they would be loyal to the Christian prince and that he was their deliverer. The young Khama resisted his father Sekhome when he ordered him to attend the heathen rites in commemoration of their success in foiling the unconquered Matabele from destroying Shoshong. Sekhome, in anger, disinherited him. He ordered his people to kill him, but the people rose in favour of Khama and Sekhome fled. Khama reinstated him. Sekhome used witchcraft to effect his son's destruction. The spell of superstition was as great amongst the Bangmangwato in these days as it was amongst the Matabele. They deserted him. 
Sekhome plotted for the death of his son, and the chief whom he elected as his heir, in place of Khama, rose against him and drove him from Shoshong. In his hour of despair Sekhome sent for his son, and Khama won back Shoshong for his treacherous father. He left Shoshong with a band of followers and returned when his father died and ousted his younger brother Khamanie from Shoshong. $\mathrm{He}$ did not kill the young usurper. In this brief outline of Khama as a prince it is seen how faithfully he kept the com:mandment "Honour thy father," and as king he immediately abolished witchcraft and drink. He knew the evils of both, and henceforth there was to be no more "smelling out" leading to deaths of innocent victims, and no more beer-drinks leading to violence and corruption. The strength of the man in face of opposition all through his life is a splendid example of Christian courage.

Sekhome, his father, had been impressed with a Lutheran missionary and allowed him to teach his sons. Later Khama went south to listen to Moffat who was preaching amongst the Bechuana. In these early days the youth had already embraced Christianity, and in spite of all temptations to revert to the ways of a heathen potentate he never swerved from the conduct of Christian principle. He resolutely put his foot down against the drink traffic. He had enforced the law against brewing native beer and he watched 
that no waggons crossed his border to sell cheap spirit to his people. In 1888 he granted a trading concession to Messrs. Johnson, Heaney and Borrow and this grant was the outcome of the Bechuanaland Trading Association.

Khama always had his people as his first consideration, and his inducement to grant this monopoly was in the first place to give an opportunity to his people to purchase ploughs easily, and secondly he could control the drink traffic. Monopolies are always bad and Khama was distinctly shrewd. He knew that a free method of trading would encourage drink smuggling.

On the granting of the Charter in 1889 Khama left his old capital Shoshong and formed a stadt 70 miles further north, where there was an abundance of water and good lands. $\mathrm{He}$ was not slow to see the advantages of the coming expedition to his own people, and the Bechuanaland Trading Association supplied them with their wants until they could reap their harvests. The introduction of the plough drawn by oxen and managed by men did away with the old system, of every Kaffir race, of the women tilling the fields with Kaffir hoes.

I must not break off without mentioning the name of Khama's able adviser, the Reverend Mr. Hepburn, but as Palapye is now in its first year and we are recording events of the Pioneers of 1890 we will take a look at Lobengula and events up to this date. 
Lobengula was the son of Mosilikatze (Umziligazi) the founder of the Matabele kingdom who had traversed the Transvaal, ravaged Bechuanaland and defeated the Makalaka tribes and established Matabeleland. Lobengula was a son by an inferior wife, but as there was no son by a royal wife he was elected by the people on the death of Umziligazi.

The Matabele race had forced their way into the country by superior military skill, and as a military race under a despot they ravaged, plundered, murdered : north, east, south and west. This was the government Lobengula was elected to, and he maintained all the blood-thirsty proclivities of his deceased father. Tribute was enforced by the monarch from all the chiefs hundreds of miles around him, and every year the tax-collectors went out to receive the demand which was subject to the will of the Black Monarch. There was no established tithe. A group of sixty Matabele warriors appeared at a chief's Kraal and he was told what the king requested. Resistance in any form meant speedy punishment. Runners would convey the intelligence to other groups of tax-collectors, and in no time there would be the convergence of these sixties to the point of attack until two to three thousand fighting Matabele would hurl themselves at the offending stadt, raze it to the ground, kill the chief and all the men and carry off the women, 
children and cattle. The Makalaka and the Mashona had no organisation, and never went to the assistance of any neighbouring chief, thus facilitating the work of destruction for the marauders. That was only a punishment for passive resistance of a tax and the terrible massacres took place long after the occupation of Mashonaland by the Chartered Co., to which I shall make reference further on.

There has been much written of the annual beer-drink and dance. There was the little dance preceding the big dance when the warriors and the women danced until they dropped with exhaustion. The witch-doctors were busy the while and the slaughter was tremendous. To the Matabele mind the more subjects ruthlessly destroyed the greater was the prestige of the monarch. Nobody was safe-excluding white men-a wife was told to hang herself and forthwith she did. A brother was "smelt out" and knobkerried and his estate confiscated.

Lobengula, jealous of power, killed every man that he feared was getting too popular or who was getting too rich. So he swelled the number of the herds of royal cattle, and so he denuded the land of the best men who might have helped to save his throne for him at the time when it was imperilled and overthrown. This mode of government was the typical Zulu one and Lobengula reigned as a monarch of that order. Had 
Lobengula embraced Christianity and foresworn murder and rapine his indunas would have risen against him and chosen another king. I mention this because you must realise the difficulties the missionaries had to contend with when preaching the Christian doctrine to this people. Another point, Khama's people were a broken race, scattered by the Matabele. It was Khama who gathered them together, and encouraged remnants of other tribes to come in under his sway, and thus built up a nation, whilst the power of the Matabele, established by militarism, was destroying itself by murder. New blood was drafted into the impis, but it was poor stuff, compared with the old fighting stock. The children, that were saved with their mothers, grew up and were recruited into the impis. These Mahoolis, brought up in slavery and whose fathers had been cowed by defeat, could not inherit that fearless and intrepid spirit which went with the old Matabele warriors.

These young bloods were turbulent at the king's kraal when the big dance was on, and had the bravado to shout that they wanted to "dip their assegais in blood," but they had not met an enemy yet who would stand up against them. The cruelty of Lobengula to his subjects and his neighbours cannot be smoothed over As a menace to everyone else he could not last, but there is no doubt that he believed that as long as he 
did not come to grips with the whiteman the old regime could continue. Moreover, his nation demanded that it should continue. With regard to his treatment of white men it was honourable. He gave them their protection and no Matabele robbed a white man without paying for it with his life to his king. Even when he fled from Buluwayo in '93, the two white men, who were in Buluwayo when the Chartered troops invaded the country, were found alive. He had given the order to his people on no account to molest them. The missionary station also at Hope Fountain was left intact. In the rebellion of 1896 the Matabele destroyed the homes of the missionaries, Mr. Helm and Mr. Carnegie, but did not burn the church. There is a difference when Lobengula had gone to rest, when his restraining influence had passed away, for in $\mathbf{1 8 9 6}$ white men, women and children were slaughtered ruthlessly and property burnt to the ground.

It was this wonderful power over his people that enabled hunters to travel through his country unmolested, and missionaries also. Once they got the royal permission they had protection as well. When displeased with a whiteman he expelled him, he did not destroy him. You may argue that he feared a nation that had destroyed the Zulu power, but at a time when he destroyed his own kraal and fled from the invading men of that nation, what restrained him from not throw- 
ing those two white men in the flames? His promise. "There is a wall built round the word of a king." That was his own expression and, whatever may have been his reign, his treatment of white men and the manner he kept his word with them cannot be allowed to pass without eulogy for this grand old savage.

We are now faced with a very serious and grave problem. We are off to join the column at Shashi. That is our rubicon. Hitherto we have been in disputed territory, which is a belt of land between the Macloutsi and the Shashi. and claimed by Khama and Lobengula. Across the Shashi you are in the country of a potentate who sits far away in Buluwayo, but is welladvised of the happenings in his enormous kingdom, for the native has a system of telegraphy that has always puzzled the white man in the swiftness of its despatch. News travel from the hill-tops at express speed and soon the shout will be the white men have crossed the Shashi.

The Poineers must cut the road and the road must go to the North.

They did cut the road. You know that. It is history. Yes, yes, my masters, but you do not know the story of who did the good work for the Empire. I am telling you that. We will go back these twenty-three years and live amongst these men again. I will talk to you in the present tense because although it is past history, the work 
lives to-day and the glory of the British Empire must ever be with us. The old axe-man may be sharp and incisive in style but lucid. These pens are not to my liking and I would sooner cut the road again than serve you elaborate and garnered report. Bluntly speaking, I leave that to the fiction-mongers. This is a true story. You must take your history as the axe-man cut his timber. You may call it lumber and not polished oak. It is British oak, straight from the axe-men who cut the road. It is the dry bones of history and we will come in contact with the warm flesh and young blood of Old England's Empire, but they will not be clad in spun silk or cloaked in velvet. No, no, these men are in shirt-sleeves, axe in hand, and we must take the timber of the Pioneer as it leaves his hand. 


\section{Chapter IX.}

Lieut.-Col. Pennefather-Captain Forbes-Captain HeymanThe Vauder Byls-Officials at Buluwayo-Radi KladiThe cutting of the road-Selous-Sentry's dilemma.

IT was about 26 th June that we rode into Tuli and joined the main column at Tuli. Here our last recruit joined us, McKay. He came with Condon and Beaumont via the police camp at Macloutsi. Condon and Beaumont were allowed to follow us as prospectors.

McKay was a tall, jovial man, good at repartee and a useful man at the camp-fireside, for he played the banjo well and sang a good comic song. Hunter had his violin and Fletcher his flute and they helped considerably to keep us cheerful. About this time a man named Grant insisted on joining the Pioneers so strenuously that Major Johnson-who refused to enlist him-sent him to the police camp at Tuli under escort. We heard subsequently that he scared the B.S.A.C. officers there with his eccentricity for one of his pranks was to hold a revolver at Willoughby's head. He was sent down country as he was adjudged to be insane.

Lieut.-Colonel Pennefather, our O.C., was here with "B" Troop commanded by Captain Forbes, 
and "A" Troop rode in about 29th June, Captain Heyman in command.

Lieut.-Colonel Pennefather of the Inniskilling Dragoons was a tall, slight man, small headed and featured, irascible, petulant and disliked by his officers, and the men were waiting to note his calibre.

Captain Forbes, fair, medium-sized, a British bull-dog, grit right through he proved himself to be.

Captain Heyman, tall and dark, a good shot, had served ten years in the Cape Mounted Rifles. He was a great acquisition to the B.S.A.C. Police.

Charlie and Gerard Vander Byl are here, and are in "C" Troop, commanded by Captain Turner. They speak well of him. They are the sons of Mr. Laurence Vander Byl of Capetown, and Charlie and I were three-quarter backs to the famous old Hamilton Football Club. I gave Gerard Vander Byl a fox-terrier pup to keep for me, as "C" Troop of the police are to be left here to make a fort and garrison it. The site chosen is on a hill, which overlooks the Shashi, and is a solid granite rock of huge dimensions and impregnable on three sides.

The river Shashi is a sandy stretch five hundred yards wide with clear water trickling close to the bank on our side. Rumours are already rife in camp that the Black King has sent envoys to say we must not go beyond Tuli. The Pioneers 
have already crossed the Shashi and cut the road a few miles ahead. The country is thickly wooded with mopani, interspersed with the giant Baobab. To the east between the Shashi and the Crocodile are huge graceful palms. Tuli is named after a river which flows from Matabeleland into the Shashi river, about twenty miles above the present station. As we were on the eve of a great undertaking and at the mercy of the mood of Lobengula, there is no doubt that the name was significant of nothing, but that astute agents of the Charter Company, Major Maxwell, Johann Colenbrander and James Dawson would tell the potentate that his waters ran peacefully past the station-into the Shashi river-and as we started in early July they would have seen that he got his monthly payment and got the receipt from him. At this time Lobengula sent Dennis Doyle to tell us to go no further than Tuli. Doyle was indefatigable-he was always somewhere, distance no object-wily, astute, a perfect native linguist, and a fearless colonial. Doyle bumped into Tuli and saw Jameson and Pennefather and bowled merrily out of camp again for Buluwayo. At Tati-where existed a gold mine worked by right of the Tati concession-he was informed by Sam Edwards that Lobengula was wrath with him, so he turned back to Palapye to study the progressive Khama whose hereditary rights of manslaughter had been tempered to Christian 
principles. Lobengula like our Henry VIII was best left alone when the liver was out of order. Both obese majesties had a disrespect for human life. It is no digression to point out here that characters take their places on these pages as they played their part, and that Mr. Rhodes was ably and faithfully served to fulfil his dream which led to the acquisition of Rhodesia.

Jameson and others will come on the stage. Meanwhile the scene lies at Ipagee-a pretty stream fringed with good timber-fifteen miles from Tuli and the chief actor was Selous for none knew the way but him.

He rode ahead on one of his fine hunters and pointed to a tree, a pioneer sprang to it and felled the obstacle. Should it be a forest giant two men tackled it and Mangwato boys steered its fall by means of a rope. These boys dragged aside the timber, for the orders were that the pioneers were to cut down trees only, so that Selous always had pioneers to issue orders to. The moment your tree fell you walked rapidly past your comrades employed ahead of you and took your station behind Selous. He indicated an arborial victim and you sacrificed it speedily. Hard, muscular, glorious work, such as Gladstone loved.

Radi Kladi-Khama's brother-was in charge of the Mangwatas. There were 270 of them. Two hundred were on foot at this work of timber 
clearing. Seventy were mounted and acted as scouts. We were not afraid of Radi Kladi, he was a clean good-looking Kaffir, well dressed, and mounted on a serviceable "salted" horse. He loved to chat to the pioneers, and some of us answered him cheerily and others snubbed him according to temperament. We stood in awe of his boys, or more correctly their guns, for many were armed with ancient blunderbusses, charged with slugs, and they would come up to one with the beastly thing full-cock and carelessly pointed. Sometimes they went off with a k-r-r-bang, a pioneer would jump and swear, but no one was hit and the dense forest could take all our language peacefully.

"A" and "B" Troop of the Pioneers cut the way right through from Tuli to Salisbury alternately day by day. This is "A" Troop's day-if you have never swung an axe then you have lost the rhythm and music of its bite. They troop behind Selous in half-sections. Right numbers dismount, strip off all accoutrements, rifle, hand-axe, bandolier and tunic, attach them to their horses, rifle in gun bucket and held by wallet strap in front to steady it. Tunic, bandoleer, havresack and water-bottle strapped to the front of the saddle by wallet-straps. Hand over your horse to your left number and line up. In shirt-sleeves and riding-breeches, booted and spurred, revolver at your waist, you stood, brawny 
and brown, to receive a large axe distributed to you and you move off to Selous, waiting for you. His dexter finger is thrown out. You know your work. Meanwhile the left numbers, leading the mounts follow on. In case of attack you have your revolver and axe which we were swinging with dexterity. What a fight has been lost here ! Browned pioneer and axe versus swarthy Matabele and assegai. The Norseman and his axe carved his way far. This is a blood-thirsty reflection, and as the stabbing assegai was used by the Zulu races with the deadly effect of the short bronze Roman sword, we can regard it as luck that there is no record of it.

The waggons moved slowly and were strung out for a distance of two and a half miles which is readily understood when you measure the length of each waggon and its span and allow for ștoppages, such as a bullock becoming unyoked -causing the whole train to delay until the waggon ahead was on the move again. A more serious matter was Lieut.-Colonel Pennefather's not throwing his flanking parties out far enough. The extreme flanks wre never more than four hundred yards from the column, as the O.C. feared loosing his men in the bush. Matabele. warriors would cover four hundred yards in two minutes easily, and it takes less than that to create a panic. True enough, we had 70 Mangwato scouts but as they, like all other native. 
tribes, had been cowed by the Matabele, it is reasonable to suppose that they were not far from the main column when scouting.

To continue, at midday we halted the march, off-saddled our horses and fed them. outspanned the oxen and grazed them near the convoy, cooked our rations and ate our lunch, smoked and lounged until the command of saddle-up was given. Whilst this was being done, the cry of "Eenspan" or "Li Bopele" could be heard from the conductors. Selous was in advance again, left numbers were his axe-men and right numbers followed with the horses.

Between four and five Selous would be looking out for a likely spot to laager, two ways would be cut to facilitate the incoming waggons, going alternately right and left. This was a busy time for it needed the extra clearing of trees. The leading waggons were sent ahead to form the north side of the laager, the front wheel of the incoming waggon was brought to a standstill just past the hind wheel of the one in front. Once the north side was formed the laagering proceeded rapidly for, as stated, they were moving in two columns. The two sides completed in the same manner, front wheel just past the hind of the waggon in front, the rear waggons forming the south side of the laager. By this method the disselboems and trek-gear of the waggons were outside the laager. The cattle after having been 
well grazed were tied to the gear. These successive teams of bullocks as they settled for the night were an effectual means of breaking a Matabele rush. The horses were picketed inside the laager. The men slept under the waggons. Frequently at night a false-alarm would be given, when the men would man the waggons, four to a waggon, rapidly make a barrier of the waggon loads, Boer meal, biscuits, tinned meat, or ammunition and await the Matabele or the dismiss, and then gladly and quietly make for their blankets.

While laager is being formed the horses were watered and grazed, guards mounted and outlying pickets posted.

As "A" Troop had done the chopping, " $B$ " Troop would find the guards and pickets; to-night and to-morrow "A" Troop would supply the sentries. The column has now reached Umzingwane, thirty miles from Tuli. Umzingwane is a rapid-running river and the heights of its banks tell of the body of water coming down in the rainy season. This river takes the waters of the Matoppo hills and of Balla-Balla, of Matabeleland, and flows into the Limpopo. On this river in Matabeleland Gambo had a large kraal. He was one of Mozalekatsi's principal indunas, and you will recall Mozilekatze or Umzilekatzi was the founder of Matabeleland and the father of Lobengula. 
That was something to go to bed with here on outlying picket. But to-morrow we must cut a drift, for the banks of the river are steep. I am awake and Sergeant Suckling is getting ready to relieve sentries. You know the system, two hours on and four hours off, between six p.m. and six a.m. Mine is the middle-watch-troopers settle that by drawing lots, and here at two o'clock I am being marched to relieve Jack Grimmer. We find Jack perched up a tree and "growsing."

"What's the matter, Grimmer?" asks Sergeant Suckling.

"What the devil do the Chartered Company think of us, bringing us here as food for the Matabele or lions? A lion has been fooling round here for the last hour."

Here was a cheerful prospect for me and I proposed to Suckling to dispense with this damned post. No good. He marched away, taking Jack with him, who said: "You are going to have a lively time of it, Bert." I had it. Intermittently between two and three an animal was sniffing round, sometimes near my legs. It was pitch dark but at three the first glimpses of dawn would bring light on this subject, meanwhile, that hour seemed ages, that beast too frequent in his visits, and I was in a cold sweat. When it was light enough I patrolled to the next sentry, who was Lionel Cripps. He was as pleased to see me as I 
him, and told me a hyena had worried him for the last hour, and he had but recently been able to distinguish it. As day dawned and the light grew strong donkeys could be seen tethered to a waggon of the laager in our rear. The hyena evidently scented the donkeys and wanted to get to them, but could not find courage to do so unless we were asleep. That infernal quadruped had kept three of us on "tenterhooks." and as a "fellow feeling makes us wondrous kind" Jack grinned at us when he heard the solution.

We have a searchlight that throws its penetrating rays around the country of a night. If the Matabele intend to come they cannot mistake our camp, for it must be discernible miles away. On the other hand we will not be surprised with facility. The searchlight will expose to view the moving body of the enemy, the sentries will give the alarm and the laager is a fortress that will resist any onslaught except well-defined artillery fire, and that the Matabele do not possess. That inquisitive hyena was deterred from his marauding by the searchlight, but never allowed himself to be exposed to its rays. Matabele, skilled as they are in silent approach, could not in a body take cover like this cunning hyena; so far the hyena is the only visitor. The searchlight scares the lions evidently. It is an uncanny thing to the denizens of the forest, may it help to awe the superstitious Matabele. Such are the reflections of the sentries. 


\section{Chapter X.}

The road cut 50 miles-Camp life-Selous and Laer-The Burnetts-Darling and diet-Father Hartman-M'tibi's Kraal-Bubye-Selous at home.

The Pioneers have cut their way to the Umshaketsi-fifty miles-a dry river, water running under sand. We had to make pits for water which bubbles through the disturbed sand. Children at the seaside come before me whilst at this game, but they are startled away for Halkett tells me that seven lions were seen in the bed of this river basking in the sun, and that they got away. Although Selous is our hero I cannot urge Halkett to lead me to them, for the hyena recollection is vivid with me yet, and I am not collecting for Hagenbeck. We have a trooper, Yankee Brown, who has a commission to collect specimens for the Smithsonian Institute. It was a little later in the expedition that Yankee Brown got permission for himself and me to go cheetah-raiding. Natives had found the lair and he had gone out and shot the mother, and together we secured three fine young cubs, who clawed and bit us before we got them into nose-bags. We lay in waiting for the father, but did not get him, and had a dreary march to catch up the column, which had long ago formed laager. 
The smoke in the laager is very trying to the eyes, for there are many pots a-bubbling and a-boiling for many hungry mouths. You are welcome at any fireside, and sit down and chat here and there. I often go over to the transport lines, for I have a young chum there, Freddy Laugermann. He is the baby of our expeditionabout seventeen - and he is attached to the transport, and I have many a pleasant chat with Ted Burnett and his brother George. The Burnetts. are well-known Kimberleyites and fine sportsmen. They are in command of the transport. George had lost his left hand, but the right one is good enough for four. $\mathrm{He}$ is a big, fair, jovial man. Ted Burnett had been a comrade of Johnson, Heaney \& Borrow in the B.B.P. He is not as bulky as George, hard as nails, rides like a jockey with a very short stirrup, and rides a beautifinl blaanw-schimmel. George rides a spirited animal of Arab strain. Amongst their transport boys is Laer. This is the boy whom a lion attacked and would have killed had not Selous shot the lion: when he was in the act of worrying him. In: Selous' book there is an illustration of this. I was amused to find Laer bore a grudge against Selous.

"Baas," said he; "Mkoos Selous ought to have shot him before. He can shoot anything. He let the lion play cat-and-mouse with me first and then shot him." 
“No, no. You and the lion were mixed up. He had to avoid shooting you and yet hit the lion in a vital part. He did quickly and saved your life," answered I.

"Yes, he saved my life, that's true, but he could have done so sooner."

The fact is that Laer in his fright imagined himself longer under the lion than he was, and he had such an appreciation of his master's skill that he thought he could kill anything in a flash. The boy was not ungrateful of the act, but it should have been done immediately.

A contrast to Laer was Jan Selous, a Mangwato boy, who had been with the hunter for many years and could not be induced to leave his master, not for all the gold in Mashonaland. The boy's name was Jan, but he had adopted the great hunter's surname. The process was Selous' Jan, that is how he would be described, and later Jan Selous is how he named himself.

We crossed the Bubye and its tributary, the Bubijan, when we had been three weeks from Tuli, and we were now in Banyailand. The country here is very good, the trees are larger, and granite kopjes are dotted on the landscape in profusion. Darling shoots a monkey in this vicinity, cooks it and invites me to the feast. This I declined, on the assumption that it is next door to cannibalism. He told me that may be so in my case, but not in his. I watch for symptoms in 
Darling on the march. The Basutos ate the heart of Wepener to make themselves as brave as that fine Dutch warrior. I find this monkey-feast has made Darling a funny man.

Major Johnson's martial spirit rouses him to provide us with a field-day, and it has an excellent result, for Dr. Jameson espouses our cause, and night-alarms and field-days are abolished. $\mathrm{He}$ offered to bet Major Johnson a "monkey" that we would not be attacked on the march. Major Johnson requested the definition of a "monkey" first, but added he was willing to go a "pony." The difference between five hundred pounds and twenty-five cautioned Johnson to negative the offer.

To-day is my flanking day and I recollect after crossing the Bubijan distinctly anticipating the arrival of a new acquaintance. I have chummer with a priest and like him immensely, a liking which grew to an affection, and which was shared by many Pioneers. He is Father Hartman, a little man, hardy, pointed brown beard, dressed in riding-breeches, Norfolk coat and felt hat he looks like a trader-he is, in souls-is a Jesuit and a Mashona linguist. Father Hartman has already written a Mashona grammar Where do the Jesuits not get to? They were in Canada before our Pioneers. Laval of Quebec was a Jesuit. When the John Company was pioneering India a Jesuit priest was living in China and 
talking Chinese. He is a modest little chap and comes to see me because he is in love-with his nag. He is no horseman and is riding a little chestnut mare, well-made and in good condition, awfully lazy and very docile. She is "salted," and we procured here in Zontpannesberg. They jog along together happy, and the troopers see they don't get lost, for he knows nothing of bushcraft, and will take little excursions.

We have halted in the vicinity of M'tibi's kraal, who is a minor chief of the Banyaii, a people the Matabele call Makalaka, which means dog. This is the race that the Matabele easily conquered and despised. They are a broken, abject race, and live in irregular huts on granite kopjes. Their cattle, goats and fowls are very small. Matabele raiding and in-breeding has done this for their stock. The pasturage is good, the country, with its beautiful trees and bold kopjes, picturesque. The land is low-lying, for we are in a huge basin which is typical of South African structure before you get to a plateau. The women we see are ugly and old, and perhaps the younger are hiding, due to the kaffir version of a white filibuster. Well, we have been called that by our own people, but in justice to the Pioneers, whose expedition $\mathrm{I}$ am recording, you will perceive that this was not a man-killing episode. Rhodes had asked for the "hinterland" to be opened and the way indicated" was the north. To the north we were steadily 
cutting the way, and the axes of the Pioneers had swung for sixty-four miles now, and the road to the north must go on. We know that a terrible foe is burning to swoop down on us and leave us for the aasvogel, whilst the axe rusts and the waggon crumbles to decay. Then others must follow and continue the road-to the north. It is Mount Hampden we are making for, that lies far north yet, but we must cut the road, and that road is for the British Empire. We are at M'tibis, fourteen miles from the Bubye. This kraal, Mr. Theal points out in his history of South Africa, were on friendly terms with the Boers, and their clergymen had done mission-work among these people. That is so, but if the AdendorfVorster claims later were constituted on that it was insufficient, for even if they held a concession from M'Tibi that could not qualify, as Chibi was the head chief of the Banyai. I will come to this matter at the date when the trek was on the Crocodile in April, 1891. The date which we are concerned with now is July 23rd, 1890, and following days.

It was whilst I was doing outpost duty in the country between M'Tibi's kraal and the Nuanetsi that I had the pleasure of a conversation with Mr. Selous. You will observe on the nominai roll of the Pioneers he ranks as Captain, but he never had the slightest regard for military distinction. He had his own waggons, horses and boys, and 
wore no uniform, but was clad in his own kit. The camp is laagered behind me and $I$ am north of it on a kopje, for the moment the eyes and ears of the camp. He is coming up the kopje carrying a theodolite and stand. I shout to him that there is a fine place for observation up here, and he works his way up, for the kopje is thickly wooded. Whilst he is taking observations he tells me of the country ahead, of the Lundi River, and beyond that of a high table-land. I note the scar on his cheek which was formed through the bursting of a gun-barrel. The disfigurement is not easily noticeable. I knew it was there from his book. I tell him of Laer. He laughs over it and says that Laer is a funny boy, that he will work with others for a change but always comes back to him. We go over the incident and then he tells me of Van Royen and of Hartley. So I had spoken to Alan Quartermain on a kopje in his hunting ground, and the magnetism of the man lay in his mild serene speech and action. He has been described as slight and wiry-that is wrong. $\mathrm{He}$ is muscular, the thighs and legs are massive, but he is symmetrical, and that is deceiving, and, again, the shoulders are sloping. He stands about $5 \mathrm{ft} .9 \mathrm{ins}$., wears a fair pointed beard and has fine blue eyes. The voice is musical and he is exceedingly modest. That was the Selous manner, the charm of his modulated voice reminded you of a refined woman, and none but those who have 
looked into the great hunter's eyes can realise the beauty of those steady orbs. A lion-slayer and an elephant-hunter with the polish of Sir Philip Sydney, the dash of Sir Walter Raleigh, the intrepidity of Sir Francis Drake, and the temperate habits and tastes of an ascetic. A waterdrinker, a non-smoker, a native linguist and a chivalrous gentleman. Van Royen he considers the greatest hunter. Van Royen would have told you that Selous took premier place. These are two fine specimens, each of his race, this Englishman and that Dutchman. Van Royen, like Selous, is brave, modest and quiet. An inveterate smoker, a dead shot, mild of manner, medium height, massive frame, enormous strength and untiring energy.

Selous tells me that Hartley had a club foot, yet the rapidity with which he mounted and dismounted was marvellous. The mighty hunter makes his departure to camp, and I am left to reflect on a brave Englishman's daring escape from the murderous Mashukulumbwe, for I have but now heard the thrilling adventure from the hero just gone.

He is forty years of age in these July days of 1890, and twenty years ago, a stripling, he stood before King Lobengula and asked permission to hunt elephants and lions. Lobengula laughed at the boy, but gave the grant. His exploits reached the king's ears and Lobengula proclaimed him greatest of all the hunters. 
The Pioneers loved him and their road lay to the north for completion. He was their guide and northwards we are proceeding, for Selous is leading us along the water-shed and the Pioneers cut the way, whilst the spoor of the waggons leave the track, and many waggons following define it permanently and make a South African road. It is the one thin chain connecting with civilisation, and the axes of the Pioneers are making history for the British Empire. Onward we go laagering, and then northwards until we reach Nuanetsi, and have cut the road for more than a hundred miles and the column halts to make a drift, for the Nuanetsi is a swift-flowing river with plenty of good water running over huge boulders, which the brawny Pioneers roll aside to make way for the waggons. All the work in the rivers we do, whether the Bangmangwatos fear the water or the crocodiles I know not. They only dragged the fallen timber aside that fell to the axes of the Pioneers. 


\section{Chapter XI.}

Nuanetsi - Chibi's - Lundi - Hippopotami Hunt - Bırnetts again-Colenbrander-Lieutenant-Colonel Pennefather.

THE column has passed the Nuanetsi and is forging its way slowly and surely to the Lundi; and we will take a cursory glance at the country around the Nuanetsi and affairs of the Pioneers. Good pasturage, still a country broken by kopjes, well-watered, and heavy mists, cold and soaking, hang over here in later months. The Nuanetsi is one of the many rivers that flow into the Limpopo and close to where they meet is the old Fleures Drift of the Boers; from here a hunters' road travels along the Nuanetsi. It was this draft and this hunters' track that caused anxiety to the officials of the B.S.A. Co. later, when Touis Adendorff and Barend Vorster proclaimed they had a concession. Game is not seen because of the noise created by axes and trek-king waggons, and on account of the thick bush they easily move off unobserved. The people of M'Tibi's readily trade with us, and in return for beans, pumpkins, monkey-nuts, honey, earthenware pots, mealies, fowls and kaffir beer we give them salt or the empty brass cases of the Martini-Henri cartridges. The latter they cherish to convert into 
snuff-boxes, to be worn in the lobe of the ear, which has long ago been mutilated and distended for the reception of similar articles. Salt is a luxury with them and they divide it and eat it, as white children do sugar, with gusto. This share and share alike amongst all natives is a pretty custom. It only refers to eatables-not their property such as cattle-but that custom is a lost art amongst most of us.

The jwala-kaffir beer-is in demand amongst us because it is a bread-raiser and we have not got "sour-dough" ready always, due to the trek. The earthenware pots are wanted as cooking utensils, for most of the pots allotted to the Pioneers are smashed. The method is to tie them to the long waggon of the conveyance, and where the waggon hits a stump there is left behind remnants of wrought iron. Our own particular mess was twelve when we started from Tuli. That dwindled down to six. That number being still inconvenient for one mess-orderly to attend to after his work at chopping, most of the Pioneers are in messes of four. Halkett and I mess together, for we find that most satisfactory, as each knows that when the other is on duty his food will be brought to him and his horse attended to, and we worked together without a hitch through the whole campaign and decline to be incorporated into a larger mess, and-as we are both on excellent terms with our comrades-that 
would have been easy. When a man belongs to a big mess he is apt to be kept waiting when on outlying picket, and his horse neglected.

Cooking-pots are at a premium amongst the men, but they adapt themselves to circumstances. Meat is cut small and roasted on a ramrod. Bread is baked in the fine ashes. It is the as-koek of the trekker. Your patrol tin which you carry attached to your saddle is most useful. In that you make your tea or coffee, or-provided you cut your meat and pumpkin small-a savoury stew for two.

The Pioneers have reached the Lundi River and are camped here for a few days to rest the cattle and other reasons.

The day following Mr. Selous and a small escort - to which I belong-cross the Lundi and gallop N.W. to Chibi's stadt. It is situated on a kopje and can only be approached in single file along a footpath wending its way to the summit. We give over our horses to our half-sections and climb the hill. The chief greets us and Selous returns the salutation. Selous and Chibi have an indaba. Chibi-which means headman-is seated outside his hut surrounded by his indunas. He tells Selous that he is the head of all the Banyai and defines his boundaries; he also admits the supremacy of Lobengula and that he pays tax to him. Selous explains to him that Rhodes had a concession from Lobengula to seek gold and mine 
it, that the expedition is a peaceful one, that the road will be maintained through his country, but that the white men would on no account interfere with his people or their lands. He knows Selous, for this mighty hunter has been in Banyailand, which abounds in game. Here are to be found the giraffe, the koodoo, sable-antelope, and all manner of buck. Hunters would have to get their permit from Lobengula. Chibi would not risk his life by incurring the anger of Lobengula. All this we must recall when we discuss the AdendorffVorster bogus concession from Chibi.

The day following Sergeant-Major Mahon told me to saddle and report myself to Major Frank Johnson.

"You make yourself look smart, young man, you are not for duty," said he.

"Hullo! Hullo! That sounds all right."

Johnson met me at the doorway of the officers' mess tent and informed me that he had invited me for a day's shooting. "Have you had breakfast?" said he.

I found Freddy Langermann already inside the tent stowing away stodgily at a breakfast a trooper seldom indulges in. Perhaps it is better so, as he has to do the work, and rich fare and hard work do not agree.

I sat down opposite Freddy Langermann and taxed my capacity as far as even a healthy trooper dare, despatched the mess orderly for cigars; but 
as he ignored the order I was content to light my pipe and overlook the matter.

Major Johnson, Captain Heyman, of the B.S.A.C.P., Capt. Ted Burnett, Fred Langermann and I rode up the river in quest of hippopotami. About three miles up the river we came on a deep and likely pool, tethered our horses to the trees and took positions on the banks. We had to wait some time, for the burly brutes were shy. They have to come up to breathe, though, and presently nostrils protruded from the water and we fired. That is all you see of the hippo and you have to shoot quickly for the moment his lungs are filled with air down he goes. We remained here a few hours and then rode further up, where we came upon an immense lagoon festooned with reeds. We cooked and ate our lunch, watered and fed our horses, and sought cover on the river-side. This was a hippopotamus home and we fired incessantly. The artful hippo could be seen pushing his nose under the reeds to escape observation. Major Johnson, having decided to get a more suitable position, forced his way among the reeds, and later we heard a yell from him. On running to him I ascertained that he had walked on to the back of a hippopotamus, indistinguishable from the slimy mud amongst the reeds. The hippo in astonishment had splashed into the water, upsetting Johnson. It was so ludicrous that I sat down in the mud and laughed heartily, and the 
officers chaffed him for not "sticking his mount." The next man to look for a position was Ted Burnett: and he suggested to me the other side. We stript and were in mid-stream when Johnson put a bullet close by us.

"What are you doing, Major?" shouted Burnett.

"Potting a big crocodile," replied he.

Burnett and I hurries on, but as we had to keep our rifles dry-each of us had rifle and bandoleer held in the air by the left hand-and one arm free only, in both cases, to swim with, the pace was not so fast as we would have liked under the circumstance. When we scrambled out on the opposite bank we heard Major Johnson laughing at us. Ted Burnett remembered this the next day. We found good spots and took up our share of the hunt. On the ride back to camp I thanked Major Johnson for the day's sport.

“That's all right. Come down to the pools tomorrow, we have got to see what luck we have had," said he.

The next day we rode out, taking boys with us. The dead hippopotamus comes up after twelve hours. We found one hippo in the lower pool, and as the carcase had drifted to shallow water it was easy to wade in and fasten a rope round the body and drag it ashore. Two others in the lagoon were brought out with equal facility. 
A carcase that had not been caught by the current was floating in mid-stream and I volunteered to swim out. Major Johnson said he would come also. Both of us stript and plunged in, but we had not gone twenty yards when: "Look out, Johnson, a crocodile near you!" Burnett shouted. Major Johnson went back to swear at himBurnett was getting even over yesterday's event. I went on, made a half-hitch round the hippo's neck and mounted the carcase, and together we were hauled to land. The Mangwato boys pointed out the teeth marks of crocodiles on the hide of the hippopotamus, but-I have none on me.

I learnt that day what a spirited horse Lieut. George Burnett rode. I have told you he had one arm only. His brother, Captain Ted, wanted Meers brought out to him, and George Burnett offered me his mount, as mine had indifferent pace. He cautioned me not to touch him with a spur as I set off, and going through the bush I must have done so. He bounded through the bush at such a pace that I was thankful to pull up at the Transport Department, find Meers and transfer the saddle to him, and lead George Burnett's fine animal back.

The Pioneers had hippopotamus bacon for days and excellent fare it is. After cutting the meat in strips you fold it and tie it with wire and cook for twelve hours. Eat it cold as you do ham.

The Mangwato boys and Radi Kladi leave us 
on the following day. They are returning to Pilapye to do their ploughing. They also have a dread of crossing the Lundi, which is the boundary between Banyailand and Mashonaland territory. Moreover, this Lundi is the largest and most difficult river we have met, and it is probable the Mangwato does not want to be caught by the Matabele, and his retreat cut off by the Lundi.

The day is spent by the Pioneers in making sandbags and depositing them in the river. Selous is the first to strip and help carry in sand-bags. He swims with a strong stroke, too. We have hours at this, and Selous calls me out of the water and tells me I am courting fever, for I had stuck this water game longest of all. He tells Captain Heaney thai I require brandy-this from a staunch teetotaller-and armed with the requisition, after dressing rapidly, I go in search of Jack Spreckley. The Pioneers have a nightly "dop" call, and the Cape brandy supplied is good. As Heaney's requisition simply reads, "Give Darter brandy," Jack Spreckley is at a loss as to quantity. I solved it for him by handing him an empty water-bottle. My circulation is soon restored and I am back amongst my comrades; and as there are good "pointers" in every regiment my water-bottle is rapidly depleted.

We made the drift and crossed the next day, and had barely finished the laager when Johann 
Colenbrander overtook us and delivered Lobengula's message to Lieutenant-Colonel Pennefather, that "the column was not to cross the Lundi." We had already done so.

Lieutenant-Colonel Pennefather tells Johann Colenbrander that "he takes his orders from Rhodes not Logengula."

"I have been told to go to Mount Hampden and to Mount Hampden I go," said our O.C.

Johann Colenbrander receives it in grim silence. He is a strong-built Natal Colonial and in great favour with Lobengula, and in the employ of Rhodes. Colenbrander had in the Zulu War fought a hand-to-hand fight with a Zulu warrior. The Zulu had nearly brained him with his battleaxe, but Johann fought on until he wrested the weapon from the hands of his opponent and killed him with it.

A splendid Kaffir linguist and a dare-devil. He did excellent service in the Great Boer War under Lord Kitchener. 


\section{Chapter XII.}

Anxious vedettes-Tokwe-Venables and Finucane-Providential Pass - Victoria founded - A football matchZimbaleye-Ruined cities-Mashonas-their country and habits.

WE doubled our sentries on this night of August 10th, that followed the day of Lobengula's message. Colenbrander had stated that the king had great difficulty in holding back the young soldiers, and if he had given the command they would be on their way now. Sergeant-Major Mahon posted the sentries himself that night; and I do not think it would be easy to find another man more energetic in keeping a man alert by pointing out the danger of his post. He showed me the exact spot the Matabele would come from - a break in the hills-and left me on "tenterhooks" for two hours. On meeting the other sentries, on turning into my blankets, I found that he had discovered a Matabele spot in front of each of their outlooks. He certainly was a champion for scaring a young soldier into alertness.

The searchlight was in play all night, throwing its rays on the hills, across the bush, up to the heavens and back again. In the morning we greeted the sun and its penetrating rays with 
joy: but the bush gave no sign of the tread of Matabele, nor was there a glimpse of their warpaint. We had to sand-bag the Tokwe, for it was a swift torrent. The waters swirled the bags out of line and sent them yards down the river. There were boulders at hand, and these we dropped in the river until we had formed a ledge. and behind these we placed the sand-bags. Once we had formed this it was easy to place the other sandbags, but it took some time to gain a footing for the first layer.

We crossed the Tokwe and the country ascended rapidly to a pass ahead of us. There was a strain of anxiety easily discernible on every face, whether officer or trooper. That pass had to be made and we were making for it, and the road was being cut through it to the north, but-who knows that in that wooded pass the Matabele may be lurking in ambush? With the column extended on a steep gradient, with frowning hills on each side for the enemy to rush down from, we were in a predicament that was not good to contemplate too long over. It was an ideal spot for a "wipe-out," but as we were in the position to supply the sanguinary matter it made all the difference. We could not make the way through the pass in a day. We laagered half-way and manned the waggons.

That night the searchlight scanned the crags and sides of the mountain. Few of us slept, and 
a hand was constantly extended to assure yourself that your bed-fellow-the Martini-Henri riflewas warm and in close proximity. The noncommissioned officers, too, would appear suddenly and reassure themselves of the readiness of the men. In the midst of the still glamour of this expectant night the Irish brogue of FinucaneSergeant of "B" Troop-broke in on its quietude.

"Where are ye, Venables?"

"Here."

"P'what are ye doin'?"

"Praying."

"Got yer gun handy?"

"Yes."

Venables, with his lank lean body and serious face, might have stepped from the rank of the Pioneers back to the times of Cromwell's Ironsides; and he would not have been out of place. His comrades had long ago dubbed him "PraiseGod-Barebones," but to-night his devotions appealed to even the slackest amongst us: but, nevertheless, the humour of the situation was not lost.

We got through and with fervour named the pass Providential Pass.

We crossed a beautiful stream of clear water and fringed with graceful ferns. This we named Fern Spruit, and its peaceful elegance was a welcome sight to dwell upon. We were on the high-veldt, on a plateau of rolling grass plains 
with little bush. A few miles from Fern Spruit we laagered and rested a few days, and promptly forgot the Matabele scare, for we were on the open plains now, and white men do not fear the native on the open. The road to the north was now cut for over 200 miles, and we named the place Victoria, after our gracious Queen.

The next day we played a football match, Pioneers versus B.S.A.C. Police.

Louis Vintcent captained the Pioneers and Charlie Vander Byl the Police. It was a wellcontested game, and we won by a try which I secured for our side. I endeavoured to convert, but my place-kick was a hopeless failure. That was the last game of "rugger" dear old Louis played.

That night Corporal Corderoy was mixed up with his roster again and was looking all over the camp for me. I was lying under a waggon, and at a table, under a bucksail, sat SergeantMajor Mahon telling me that he had been a very fine Rugby player in his day.

That was a preliminary. He then began to explain to me his intention after disbandment. He wanted to get together about thirty good men, raid cattle and share-and-share alike. It was lovely to listen to this Irishman. Here was the real filibuster. Corderoy put in an appearance and I promptly ducked into the blankets.

"Go and find the man," said the SergeantMajor, "or put somebody else on." 


\section{Exit Corporal Corderoy.}

I sat up and asked Mahon: "How are you going to square the Chartered Company?"

"Leave them this side of the Zambesi," said he. "Cross the Zambesi, raid cattle, and shareand-share alike"; he finished with this always.

I was enjoying the discussion and this filibustering plan so well that I had forgotten Corderoy, who had come back to report he had found somebody else for guard. He broke in on our anticipated raid and announced that $I$ was the man he was looking for. Visions of raiding promptly left the Irishman's brain and he was the soldier again. He was very shocked, as a sergeant-major he should be, and I was humble, as a trooper I would be, and when poor old Corderoy abused me for keeping him on the dance round the camp Mahon turned on him, saying:

"That will do, that will do; don't bully the man."

Corderoy was always trying to complete a guard by hook or by crook, for his roster was ever wrong; and as I had done guard but three nights ago at the Tokwe my turn would not come round for another three nights at least. As Mahon had posted me himself that night it was simple to remind him of the "place where the Matabele would come from." The end of it was that he testily got rid of his corporal and came back to the "share-and-share alike," for he was 
bent on enlisting me that night, but I spoilt the move by falling asleep.

The next day was devoted to Zimbabye, which lies fourteen miles south of the Pioneers' camp. There is a kaffir footpath running down to the ruins, so there is no fear of anyone losing himself. The country in the vicinity of Zimbabye is well-wooded and watered, in fact too wellwatered, for the valleys are swamps and the ancients must have suffered the discomforts of fever here. The city of a bygone period was aweinspiring to us, for the vast stillness was eloquent, and the traces were heathen. How long ago? Who were they? Where is their gold? Most of us searched about for that, but it was a cursory glance as we had to get back to camp. Yet we had cut two hundred miles of country-until our sinews stood out like steel wires-for the Great White Queen, Victoria.

How many queens had already ruled here? There was evidence of a white race long before us.

Vraiment, il est une fois de plus prouvé que rien n'est nouveau sous le soleil! -

The next day Jay was sent by cart down south invalided to England. Rheumatic fever had prostrated him on the way and left him a wreck. He was a gay-spirited young Englishman, who had held a commission in the army and squandered a fortune. We had been particular chums and had revelled in many a cocoa-drink, for Jay 
had brought a lump of cooca with him the size of a travelling-bag. I am glad to say he recovered and is alive.

We left " C" Troop at Victoria to build a fort and to be stationed there. The Pioneers proceeded north with "A" and "B" Troops of the Police. The grazing around Victoria is not good, as it is "zuur-veldt," and that is injurious to the health of cattle. The country on this high table-land is broken with grotesque granite kopjes, on many of which are perched the huts and granaries of the Mashona-a feature of Mashonaland. These badly-made huts on bare granite are the result of Matabele raids. A man builds a home as a temporary residence, for to-morrow the Matabele may burn it down. As it is you may wander in toilsome manner to a village and find no trace of life. They are hiding in the neighbourhood on other kopjes which have no huts but give them shelter. They are a strange people with distinct characteristics more pronounced amongst the men. Everywhere you see Eurasian features. Many a handsome profile enhanced by the gloomy expression of sorrow. These men are remnants of a nation that has constantly been raided, and seen their women, children and cattle carried off and their comrades slaughtered. They owe their lives to fleetness of foot or skill in hiding, but it has given its indelible stamp of bondage to the faces around you. It is the Arab physiognomy 
without the bold independent air. The pickaninnis are the happiest, they skip about the granite slopes like mountain goats. They are the first to make friends with us and come down from the rocks and follow us as we go north. Men and women come out of their hiding and join the procession. They soon perceive that, though armed, we are not raiders, and apparently by their astonishment have seen nothing of white men or horses.

On observance we find the horse is the attraction, and a prick of the spur or a plunge of the horse is greeted with a shout and gesticulation.

The ordinary feat of mounting and dismounting is watched for with the keenness of a Derby finish-no money on it, either! Even Father Hartmann "chucks a chest" for their appreciation of his performance; and up to now he has had to put up with the eye critical-here is a field of labour for him and he sees it, and so does Canon Balfour, who is with the Police taking note of these oppressed children.

These pickaninnis-like the children of all Kaffir tribes-were very precocious and amusing. It is held by some that the brain is very active of the Kaffir child, but progression ceases at the stage of adolescence. In this world before us now there are mixed races. I have spoken of the striking physiognomy and regularity of profile. The hair, too, although greased, is long and does 
not grow in little shrubs, typical of negroid extract. In a distance of five miles kraals are to be met whose inhabitants differ from one another in appearance and in language. You find Makalaka the same as the Banyai, and you discover people who are half Arab in ways and wholly so in appearance. Whether the Mashonas are the descendants of the slaves of the nation that worked these mines or not, they are the races that were on the spot when the Barotseakin to the Makalaka-swept over the Zambesi, descended on the Mashona and ruled him. These Mashonas rose in rebellion and drove most of the Barotse back; not all for we have passed Chibi, a head chief in Banyailand, who rules some of these people close to Victoria, and Sepiro near Mount Wedza and the Sabi River is a head chief of the Makalaka around that neighbourhood. This raiding ground of the Matabele that we are passing over now and these people who are following us-I am taking you with me, readerswere the very people that gave the "casus belli" to the Charter Company-you know the issue.

Interesting as the Mashonas are they have loathsome habits, such as the catching and eating of mice. We trade with them quite amicably, but it tries one's patience to have rats offered you in barter. There is always a procession after the horses, people coming miles out of their way. When we camp others have taken up the queue 
and stand round the fires grateful of tit-bits. They have excellent tinder, a species of cotton, which they carry in their belts, and troopers are daily replenishing their tinder-boxes. They showed us how to get it. From a thin-bladed grass they take the exterior covering, and the inner fibres they roll in their hands. The friction dries the substance and leaves a small bundle of cotton, highly inflammable. This grass grows everywhere on the high veldt, and we learnt this most useful trick from them. There are others which I will mention in due course. To return to the fireside, the troopers have become luxurious. The habit of catching a live coal on the hand and placing it on the pipe, which hitherto had to be done by one's self, is now done by the Mashona pickaninni or man, and they are more dexterous at it. Over there a trooper is gesticulating violently and others are laughing heartily. More lazy than others, he had given his pipe to a pickaninni to light. The youngster had got the coal on the pipe but proceeded to smoke the pipe. This is a frequent occurrence. They find difficulty in understanding us, and when a trooper hands over his pipe they take it as a gift. These Mashonas: grow excellent tobacco. They bring it to us in rolls and in cones, those cones being comparable with the best tobacco procurable. The smeared exterior is left and the tobacco hollowed out-as you do a Dutch cheese. Sometimes a cone is mil- 
dewed, but as a handful of salt or a cartridge case will bring you in exchange three or four cones you do not mind.

It was on the march about this time that Watney gave a Mashona a piece of soap and a shirt, which he expected the native to wash and bring to him. The shirt having had ample time to dry in the strong sunlight he went in search of it. He found it washed and dry but on the body of a native. It was another case of misunderstanding, and Watney was mercilessly chaffed over the incident by his comrades.

Natives along our route swarmed the camp, anxious to trade. They brought pumpkins, beans, rice, mealie-meal, millet-meal, kaffir corn, kaffir beer, tobacco, honey, monkey-nuts, gourds, barkbags, bark-rope, bark-string, fowls, eggs, sour milk and sweet potatoes. Money they did not know the value of, not that we had much, neither did we care. We bartered with bouilli-beef tins, cartridge-cases, salt, sugar and old kit we wanted to discard, also copper wire and beads.

Their beans were excellent and they had a variety. The rice is the best in the world. Rice is a staple dish in the South African home. South Africans-no matter how many vegetables are served-always partake of rice. This is a habit from the days of the Batavian government. It is the white rice of India that is consumed. South Africa does not grow its rice. Mashonaland 
produces the white, but has a rice of pink hue which is far superior to the rice of any other country in the size of the grain and glutinous. nature.

The rice-fields are to be found everywhere in Mashonaland. They make small circular pits, and as the country has a big rainfall no irrigation is required to flood the fields. The south-east winds are the distributors of the necessary element. Mealies or maize grow high of stalk and large in cob. Mealies give a splendid return grown anywhere in South Africa, and Mashonaland has the most favourable conditions of all. Kaffir beer is readily purchased and can easily be made. It is sustaining, besides being a thirst quencher. It is an excellent tonic for a fever patient, as it is for dysentry or enteric.

I have already spoken of the virtue of the native tobaccos: but would like to add that the settlers of Rhodesia are growing tobacco largely of good quality and are exporting the same. In enumerating the commodities obtained from the natives I have come to honey, and we get quantities of honey. This is a land of honey-no milk, bar sour. The Mashonas not only have their hives, but everywhere the honey bird is chirping to lead you to a wild hive teeming with luscious: combs. Lionel Cripps came to England after this expedition and he told me subsequently that people smirked and smiled at him incredulously when he spoke of this useful but ordinary-looking. 
little grey bird. It is a fact, nevertheless. The Mashona answers the chirp and follows the bird alighting on a tree just ahead of him. It settles on a tree and chirps vigorously. The Mashona looks and finds the hive in a tree-trunk. He proceeds to smoke the bees and robs the hive and leaves a piece of honey-comb on the ground for the bird. Down comes the little pioneer to the feast that his intelligence and man's ruthlessness has provided. We acquired the habit from the Mashona and made the acquaintance of the birds ourselves.

The monkey-nuts roasted and eaten with honey will remind you of almond toffee and is quite as nice. It was the Pioneer pudding.

Sour-milk is excellent diet for the sick, but you will procure Kaffir beer with greater facility than sour milk. That is on account of the scarcity of their cattle, due to the Matabele raids. What cattle they have are very diminutive, so are the sheep, goats and fowls.

The little Mashona cock is a plucky fighter and is undoubtedly of gamecock strain. There were many battles daily in camp, for no sooner were two purchased from different, natives and set down when a struggle for supremacy ensued. If the masters were abject and cowardly the birds had a better fighting spirit than the arrogant braggadocios of Lobengula's impis. These little gladiators had to be separated, for like the Abantu warriors they were out to kill. 


\section{Chapter XIII}

200 miles-Charter-Mount Wedza-430 miles-SalisburyUnion Jack hoisted-Pioneers as Prospectors.

THE column had advanced another hundred miles when it was decided to build a fort here and name it Charter. Mr. Colquhoun, our Administrator, Mr. Harrison, his secretary, Dr. Jameson, Captain Selous, Lieutenant Campbeli, Corporal Vintcent and thirteen troopers left the column and proceeded westwards for Mount Wedza. I was one of the troopers of this escort, and with us came Mr. Colquhoun's waggon. Finding the waggon an encumbrance after a few days the party split and pushed on to Sepiro's stadt, the head chief of the country and an old friend of Mr. Selous. The object of the trip was to inform him of the Charter, much the same as we had gone through with Chibi. I was not present at the indaba on this occasion, for Louis Vintcent, Jack Grimmer, Christison, MacRobert, Borcas and I were left in charge of the waggon and followed in their wake. Louis Vintcent was commander of our little party and took possession of the administrator's bed. I commandeered the secretary's bed and forestalled Jack Grimmer, who had designs on the position. They were only 
waggon cartels; but that was luxury after having made an impression of one's self on the veldt for these last few months. There were candles and books to read, and a quantity of excellent Turkish cigarettes. When Jack Grimmer had behaved himself I threw down cigarettes to him lying under the waggon, and when he had not done so I let him clamour for them suggesting, the while, that he should ride ahead and get Harrison's permission. Behind my head was a safe with $£ 10,000$ in gold. Louis Vintcent was deaf to any scheme of crossing the Portuguese border with that little haul. The party ahead of us had blazed the trees to indicate the direction for us, and our little party was quite satisfied with the conditions.

The next day MacRobert, Christison and Borcas were busy at revolver-practice, Louis and Jack were listlessly watching and I was preparing sweet potatoes for the midday meal. It occured to Christison that he had a revolver of his own in his kit-bag. This he brought out and was exhibiting to MacRobert. There was a report and the earthenware pot I was sitting over and dropping the sweet potatoes in, fell shattered to atoms. Christison had put that revolver away loaded in one chamber and had carelessly pointed the weapon my way. I had no occasion to expostulate, for MacRobert was rating him so roundly that one felt he was overdoing it, 
but MacRobert had lost his cousin, George Findlay, over a similar piece of negligence and he was to shoot himself six months' hence when delirious from fever. Harmony was soon restored in camp for we opened a bottle of French brandy belonging to Dr. Jameson and drank his health.

The next day Jameson came back to the waggon, looking pale, he had had a nasty fall from his horse. He promptly took the administrator's bed as he did his office later. He grinned at the explanation that we were obliged to drink a bottle of his brandy to maintain the health of the camp. Louis gravely and blushingly related the circumstance and Dr. Jameson assured him "It is all right."

In discussing this amongst ourselves we voted" Jameson a sportsman, as he undoubtedly is, and came back to his remark "Is that all ?" when Louis had reiterated "One bottle."

MacRobert, who was a Kimberleyite, expressed the opinion that the doctor meant to convey we: were "good lads" for stopping at one bottle.

"No, no," blurted Jack Grimmer, "damned fools."

Grimmer had a subtle humour and as he knew Jameson better than any of us we were inclined to agree with him. Jameson would have made a good trooper-except that much of his time would have been spent in the guard room.

Dr. Jameson gave the order to return to the 
column and the administrator, Selous, and party caught us up. It was very cold and bleak on the Charter flats at this time of the year and we were glad of our coats at night.

We left Captain Heyman and "A" Troop of the B.S.A.C.P. at Charter. They were to build a fort and patrol the country-you will meet them later elsewhere. "B" Troop and Captain Forbes, B.S.A.C.P., followed the Pioneers onward.

We crossed the Unyani and made the road north for another hundred miles until we came within ten miles of Mount Hampden. We found a spot more suitable for a township here than in the vicinity of Mount Hampden.

This was our last laager of the route. We had made the road through the "hinterland" for a distance of 430 miles from Tuli. On September 12th, 1890, we founded Salisbury, the capital of Mashonaland, and so called after the Prime Minister of England at that time.

Here the Pioneers built a fort and hoisted the Union Jack amidst ringing cheers. They had cut the road to the north, though men had said they were going forth food for the aasvogels. They bequeathed a vast dominion to the Empire and requested their countrymen to keep the flag flying where they had hoisted it, and saluted it, September 14th, 1890.

There is little to tell in the throwing up of Fort Salisbury. Looking back to that period I 
always recall Louis Vintcent and Montague Bowden. We worked in the trenches together and found amusement in it. Sir John Willoughby - who had earned the soubriquet of "Monkey Nuts" on account of his issuing an order that the Police were to be served with five nuts per man as an extra ration at a time when they were procuring for themselves more than they knew what to do with-superintended the work and had a string stretched to give the line. Time after time we broke the string with a welldirected spadeful of earth. He would halt the work to join the string with stolid patience on each occasion with the solemnity of a sphinx.

The Pioneers had already grouped themselves into little syndicates and were awaiting disbandment. The vehicles of the prospectors who had followed the expedition had already set out ; and we thought that an unfair advantage. Harman's prospectors, Johnson Heaney \& Borrow's prospectors and prospectors of the officers and police. On the day of disbandment Dr. Jameson read out a proclamation that the country was under the administration of the Chartered Company and that any man found guilty of murder or rape would be shot, etc. That was all in order, but why Jameson should proclaim and not Colquhoun was a mystery to us. He was Mr. Rhodes' representative-we knew that-but he was not nominated administrator yet, as Colquhoun held that position. 
We could get no copy of a mining law, but we were informed of the Chartered Company's claim of 50 per cent.-which we did not like.

We drew our cheques and some men sold their farm right for $£ 100$ and their claim right for $£ 100$. Johnson \& Co. were buying largely, so was Willoughby and others. These men mostly went back or found employment with Johnson \& Co.

Most of us put the cheques we had received into the hands of one of their syndicate, and sent him down country to buy dynamite, tools and provisions--they were a long time coming back. Halkett, Neumeyer, Adcock, Brand, Nowers and I formed ourselves into the "Excelsior Syndicate" and sent Nowers down country.

On September 15th the Pioneers met, proclaimed themselves burghers of the British Empire and nominated Selous their commandant.

Hartley Hills attracted the Excelsior Syndicate and they were the prospectors of Gedsema. Others pushed northwards to find the Kaiser Wilhelm gold-fields which were reported to yield good alluvial. Some went up the Mazoe Valley north-west of Salisbury, others to Lomagundis further afield. Louis Vintcent was nominated Mining Commissioner of the Lomagundis district. To that district also went Jack Spreckley and Arthur Eyre. We spread out north, south, east and west to prospect the country.

Each little syndicate had three months' short 


\section{PIONEERS OF MASHONALAND.}

rations, a few tools, dynamite, detonators, fuse, and trading goods. A waggon and a span of oxen was lent to each syndicate on condition of immediate return when Messrs. Johnson, Heaney\& Borrow called them in-which was soon.

Dr. Jameson and Frank Johnson went eastwards to explore a route through Portuguese territory to Beira. They took a collapsible boat with them-which had been brought up for the purpose-to float down the Pungwe River.

Lieut.-Colonel Pennefather went back to Tuli and from there to Natal. True enough the British Union Jack was flying at Salisbury, but the officials of the Chartered Company could not rely on that alone for protection, and they must have had great faith in the integrity of Lobengula that there would be no murder-or they didn't care.

The Pioneers distributed over the country would be an easy prey to Matabele marauders as they were in $\mathbf{1 8 9 6}$ when the country had been denuded of Police. The four forts were isolated, shortmanned and useful only for a limited distance in their vicinity. Had the Mashona risen as they did in 1896 we could not have coped with the rebellion. The Pioneers from a mounted infantry corps had gone out in small parties on foot. The horses, the cattle, the waggons, and all baggage had become the property of Messrs. Johnson, Heaney \& Borrow by arrangement be- 


\section{PIONEERS OF MASHONALAND. 111}

forehand with Mr. Rhodes. The fact of the matter is that such was the faith in the gold country that the officials thought that soon we would have several reefs eclipsing the Johannesberg main reef, and that next season the country would be swarmed with a population and weequally sanguine-were scouring the country in search of these reefs. 


\section{Chapter XIV.}

Excelsior syndicate-Hartley Hills-Gedsema-Old working: -A night out with a hyena.

THE narration of the doings of the Excelsior Syndicate will provide an idea of the actual life of the Pioneers of Mashonaland, for they would be undergoing the same task of pioneering, and meet with the same difficulties, except that they are operating in different localities.

We left Salisbury with our waggon and came across a small kraal sixteen miles south of Salisbury. Here we engaged the services of the chief's son, I should judge at that time a man of thirty years, named him Sam, and found him an excellent, resourceful, faithful boy all the time that he was with us. Sam led us a short cut to Hartley Hills and we made a road for our waggon - that road became the adopted route to Hartley Hills as it is the shortest and best way. We found Hartley Hills, and the veldt surrounding it, bristling with pegs and our bullocks could not help knocking down some of them. Two little granite kopjes named after the hunter who had been seen to examine quartz here, and was reported to Lobengula for doing so. Roach was at this place, big as life and cheerful as ever. 
The Reverend Mr. Surridge was at Hartley Hills for a while, and he was very thoughtful and kind to the Pioneers in that letters for them he received and sent out, and when he could not locate a man he passed the word through sojourners, until the man he sought learnt that there was a missive for him. In the same way he received letters for down country which the Pioneers sent to him and he saw that they were forwarded. In this manner he endeared himself to the men and many a mother heard news of her son and of the fortune which he was going to bring home to her; and then he would take her with him to Chicago '93 as most of the Pioneers had made that a rendezvous.

Everybody was going to make money quickly and everbody meant to meet everbody else at Chicago. It was the Mashona adieu and it is palpable that they wrote of their hopes to their mothers and sweethearts.

We pitched camp about five miles up the Umfuli from Hartley Hills, on the outskirts of the pegs, and built a haart-beest hut-light poles and grass erected in the form of a tent.

Halkett and Neumeyer set out for Lomagundis on foot, as rumour had reached us of its rich goldfields. Adcock, Brand and I prospected the neighbourhood and, as we had shot a wort-hog and roan-antelope, we had plenty of meat and made biltong. This is done by cutting the meat 


\section{PIONEERS OF MASHONALAND.}

into strips, salting and peppering it and hanging it up to dry. Adcock had a shot-gun and he was kept busy in warding off the hawks who seemed bent on raiding our biltong.

His shot-gun was useful on many occasions for procuring guinea-fowl as Mashonaland has coveys of these beautiful birds who scamper off and alight in the trees. The country around is low lying and thickly wooded, with fine open glades, and the men are burning the grass everywhere. It is the healthy time of the year, and as moving over the black ash patches begrimes us we bathe in the 'Mfuli, a favourite home of crocodiles. We are too wily for them because we throw two or three charges of dynamite in, which disturbs their digestion, and therefore their appetite, and also brings up the fish. We swim in and collect all the fish that come to the surface and go and grill the fish for supper, after a delightful bathe. We generally have our dip before sun-down and after a smoke and chat at the fireside go to bed, and are awake and about at five. Lions and hyenas are a nuisance at Hartley Hills and you hear reports of fire-arms nightly, for the marauders are after the oxen and donkeys. We have made a kraal for our oxen and the bush is quite ten feet high surrounding the kraal. In spite of that somebody loses a bullock nightly. The lions jump the kraals, kill a beast, and although the lions-there are 
many round-are frightened off and occasionally one is shot, they are around every night.

Halkett and Neumeyer return from Lomagundis and bring many samples of reef with them but after panning carefully there is no result of a decent prospect. Fred Brand is our expert panner, but we soon learn the knack and with practice become efficient. As we have not found anything giving a "good tail" in the pan we are discussing prospecting further afield.

Roach brought over Lieutenant Ffiennes of "A" Troop, Fort Charter, to have boar's head breakfast. We had baked the head of a worthog in an ant-heap and Ffiennes enjoys his repast. Roach had been here before and was aquainted with our larder. The Pioneers have adopted the open-house principle observed in all countries in early habitation and are always pleased to see one another and-old "share-and-share alike" is here, otherwise Mahon, our sergeant-major, who wanted to raise a body of filibusters. Arthur Eyre has come over from Lomagundis and reports Louis Vintcent and Jack Spreckley in good health.

The next day a valuable greyhound-belonging to Eyre-is caught by a crocodile as the dog was lapping water at the river in front of our hut.

Adcock, Brand and I take Sam with us and start off on a fortnight's prospecting trip, leav- 


\section{PIONEERS OF MASHONALAND.}

ing Halkett and Neumeyer in camp. We crossed the "Umfuli" and followed the river. After we had been out a few days, during which we had tested much rock and wandered many miles, we halted at a spot which Brand reckons to be an old alluvial-field, and whilst he is busy panning, Sam touches my arm and indicates a sable-antelope in the distance. He leads me over a kopje, but he is an agile and stealthy stalker and I let him go ahead and follow in his tracks. I scrambled into an old working and found a piece of quartz, studded with visible gold. The native turns round and there is scorn and impatience depicted on the lineaments of his face-he is a hunter, this Sam, and despises gold-seeking. Hurriedly, I put the piece of quartz in my havresack and follow Sam. He wants me to get closer but as it is 200 yards range I open fire and break the "swaart-wittepens" hind leg. We give chase and after a few more shots I bring him down. Adcock has followed on and I leave them to skin the buck and go back to Fred Brand still "panning " rubble patiently. On showing him my find -he doesn't listen to the sable-antelope incidenthe excitedly asks me to take him to the place where I had found the visible gold. I did so; and Fred is soon digging and scraping away with his prospecting hammer and beaming with happiness, for he finds more quartz thickly studded with gold, and he tells me our fortunes 
are made. I proceed to tell Roger Adcock that he can live in affluence for the rest of his life.

"That is all very well," says he, "but next time you shoot meat for camp you skin your buck yourself and don't leave Sam and me the work."

$\mathrm{He}$ is soon scurrying off to Brand and we make a hut, camp here the night, dine off sable-antelope steak, and dream of untold gold. The next day we send Sam to find the nearest Kaffir kraal, for this part of the country is sparsely populated, due to the 'Mfuli Raid of 1888 of the Matabeles. In one of the kopjes a few miles away he came on a small kraal and brought us two boys. Roger Adcock starts off with Sam to fetch Halkett and Neumeyer and bring back our waggon and oxen, and all our paraphernalia. Brand and I take up the reef and follow the red slate running east and about a mile from our starting point came on big old workings, with monster trees growing from their midst. The ancients have been here as they seem to have been everywhere. The place I discovered was not more than three feet deep-where I found visible gold - and had a large tree growing from it. Evidently they had intended opening up the very kopje at the point where I stumbled into their working, and they must have found alluvial-and took it away -where Brand had been "panning". We find further old workings fifty yards long, fifty feet wide and fifty feet deep. Their method was to 


\section{PIONEERS OF MASHONALAND.}

strip the reef as they went, and it shows the labour of hundreds of people. This stripping indicates that the reefs shed the gold and the red sand and rotten slate must have carried good gold and with their primitive methods of crushing-granite mortars-such rotten reef would be more welcome than hard quartz. What made them stop at fifty feet? Did the reef pinch out, or did the rock become too hard for manual crushing? Brand says he won't take less than thirty thousand pounds cash for his share, and I very nearly fall down an old working. It is rather sudden, like a proposal, this announcement, and, like a girl who wishes it had been the other fellow, I cannot help thinking that I would like to have been here before with the Phonician gentlemen with curls in their beards. They got the stuff and the evidence is before us. The natives we have engaged can tell us nothing and they are not the Arab type that one meets and I have spoken of. Our boy Sam, though, has a distinct Semitic nose-but he is not commercial. $\mathrm{He}$ is an enigma. He has told us whilst wandering to Gedsema-that is what the Kaffirs call this district-that he knew of diamonds near the Zambesi. Orientals have an innate love for gems. Sam despises gold but wants us to prospect diamonds. Rhodes has given De Beers the rights for diamonds in Mashonaland. Rhodes has the Semitic nose. He is a diamond potentate. I 
wonder if Phœnician ancestry has goaded him to open up the hinterland and with another distinct Semitic trait he has got somebody else to do the work-the Pioneers.

We got back to our camp and took the meat from the trees and gave the boys a good ration. They smile an aasvogel smile-the Kaffir and the bird admit of facial contortion when there is dead meat handy.

In the afternoon we started pegging off and ran our centre pegs down our claims, and went to bed happy. That night Brand slept soundly, the night before he had a constant nightmare that the claims might be "pegged off" by somebody else, in spite of the fact that there were no white men in this district but ourselves. The next day we squared off our claims and put in the side and corner-pegs. Brand pegged whilst I chopped the stakes, and the boys carried them from me to him. About midday Brand suggested breaking off and going back for a meal. We had our last at day-break. I told him to go on with the boys and I would follow, as I was looking for my tobacco pouch. I wandered to every sapling that I had chopped down, but could not find the pouch and would not give in. It began to rain heavily and as I was only clad in a cotton shirt and "ducks," that had once been white, I started running for home by a short cut through the bush. This short cut proved to be the longest way round 
for at sundown I found myself hopelessly lost, wet, cold and hungry. It had not ceased raining since mid-day. The rainy season had set in early and water had been streaming from the heavens for six hours. I was in for trouble. Just before it got dark I had come upon a kopje that was high and had a wall on its summit.

I had found the castellated kopje of the people who had worked these gold-fields. It was getting dark rapidly but I was able to cut a few boughs, for I had my axe-no rifle and no tobacco-and settled myself up against the wall It rained incessantly and the cold down my spine was excruciating. I might as well have been without the cotton shirt and trousers for they clung to my body like soaked dish-cloths. The darkness was intense, and I had been shivering for some time when a hyena called. The scent of these scourges is marvellous. I had made for this kopje to escape visitors. I fought that beast all night. I could not see, he could, and as I heard him near I lunged out with my axe. He would jump back and sneak up again. At the first sign of daybreak I jumped out for his scalp, for the cur scuttled down the hill and I sent stones after him. I took my wet things off and ran about until the sun got strong, and the feeling of getting warm after being benumbed all night is grand. What gold is there that has the brilliancy, or gives the happiness our old sun 


\section{PIONEERS OF MASHONALAND. 121}

brings us ? I came upon the old workings of the Sun-worshippers and ran along them and came to our pegs and presently ran into Brand's arms, who seized me in an embrace and kissed me. My poor chum had spent an awful night, as the Kaffirs had told him that I could not be alive. White men can withstand cold better than natives, but the hyena fight kept my circulation going-he has his uses. 


\section{Chapter XV.}

"Bushed" for three days-Making roads again-Pioneers' home at Gedsema-Mashonaland Main Reef-FeverLack of nourishment.

THAT incident was the forerunner of another "lost on the veldt" episode. Two Pioneers had heard at Hartley Hills of our luck from Adcock and followed the 'Mfuli and struck our camp. They were Tregenza and Stewart. We put them on to the lay of the reef and they pegged our extension. As our provisions had run out we were glad to get some tea from them, as all Brand and I were living on the last two days was meat and water. We decided to go back with them to Hartley Hills and engaged an old native to strike a direct route through the bush to Hartley Hills. Starting off the following day early after fininshing Tregenza and Stewart's rations at breakfast, thinking that we would all have a good meal that night at our camp at Hartley Hills. It began to rain at midday in torrents, and we trudged on manfully, believing that the native was taking us a direct course. About two hours later I became suspicious of his leadership and set myself to watch his movements, and later found our footprints. Clearly the native had lost himself and 
had conducted us in a circle. We halted and he confessed himself nonplussed. He climed a tree and came down, and my comrades seemed inclined to follow him again, but I most emphatically objected. The native was shivering violently, and I surmised he would wander aimlessly only to restore circulation. The first step was to make a fire and nobody had dry tinder and a flint and steel. I was the only one carrying a rifle and ammunition. Whilst they sought for dry grass and twigs I extracted the bullet from a cartridge and fired a piece of my shirt from the gun-barrel. It caught fire and the native nursed the smouldering rag to flame and gradually the fire kindled the grass and twigs. Brand, after he had made himself warm, decided to start off. He had discerned two kopjes in the dim distance and was confident that they were the Hartley Hills.

"By the time you get to camp I will have a meal ready for you," said he.

"When you get to those kopjes wait there for us as you will find yourself wrong," replied I.

He left us and with a scornful laugh strode off at a great pace. The native was thawing rapidly, but could give no sensible indication of his whereabouts. I bade him follow me and carry a fire-stick and make a fire at intervals on the march. It was sundown and light was fast disappearing when a faint "coo-ee" drifted to us from the kopjes. We answered it in chorus ; on 


\section{PIONEERS OF MASHONAI_AND.}

nearing the vicinity I left Tregenza and the native to make a bonfire, Stewart and I going in search of Brand. He came down from the kopje, very humbled and pleased to see us. On returning to the fire we found that the native had run away.

"There is only one course to pursue," I said, " and that is to walk south. In doing so we will strike the 'Mfuli. Any man who wants to strike off at any other point of the compass can do so of his own accord and get himself bushed as Brand did to-day and wasted precious time."

They agreed to follow me and listen to me and we slept round the fire that night. The nasty scars that the Mashonas have on their shin bones is due to the intense cold at night and the fact of their having no clothing. We went to bed supperless, and fairly roasted ourselves.

We walked south all the next day, carrying fire, and at night slept round a big fire. The next morning at daybreak we were a sorry hungry quartet and Tregenza was getting very mopish. In the early dawn we disturbed a young duyker - stiff with cold-and pounced on him, tore him to pieces and divided the small buck. We ate the little antelope raw, not stopping to kindle a fire. As the sun got stronger Tregenza began singing hymns and shaking his head. We caught sight of the native during the day, he was following us but would not come to us, although we hailed him. 
Tregenza was all out and wanted to lie down. Brand also began to question my route, but Stewart stuck to me like a man.

Late in the afternoon we struck the 'Mfuli and Brand cheered up. It made no impression on Tregenza. We filled our exhausted frames with water and trudged on and, in the dark, discerned a fire twinkling far ahead. We all pointed it out to Tregenza, wearily dragging himself along, still singing, or rather droning, hymns. It made no impression on him. A few hours subsequent, we struck the camp of Bill Natrass, one of Harman's prospectors, and eat him out of house and home. He had some goat mutton-traded from natives-and cold beans. It disappeared and we had five pots of mealie-meal to follow, until Bill expostulated that we would kill ourselves with over-eating. We didn't.

We struck Hartley Hills ten miles higher up the river and a few days rest saw us in good fettle, except poor old Tregenza, who went to Salisbury by waggon to the hospital. He got fever badly-we all did-and died. The native came to our boy's fire and Sam told us of his arrival. We were inclined to tie him up and thrash him for his shabby conduct, but Roger 'Adcock pleaded for him, and I told Sam to feed him and get rid of him.

We crossed the 'Mfuli where it was fordable and cut a road to Gedsema, Sam taking us a 
direct route. I discovered another trait of this boy. We got some beef at Hartley Hills, and a lion had acted as butcher. The boy would not eat incabi-which is ox,--he would only eat nyamason-which is game. This puzzled us very much and I can only account for it that the boy thought eating the beef would tame him, whilst game would help to stimulate his hunting instincts. Other Mashonas I had met would eat any kind of meat and it was disgusting to see them eat tripe raw. The Matabele gave them the name of tripe-eaters, i.e., Mashona.

At Gedzema we built a 40 by 20 feet house, with a high-pitched grass roof. We shot a good many roan and sable antelope, quagga and waterbuck, and their skins were cut up into reims and took the place of nails. These were used for our roof. The timber for the walls was tied with bark rope. The Mashona method is to hammer the bark with the flat of their axes and then strip the inner fibre. We made a double roof and therefore rendered the house waterproof. Hyenas were a nuisance at night dragging hides and reims away. Neumeyer had a fox-terrier with two pups, and one night they were so troublesome that he put them in a sack and threw them outside. They were gone the next morning, sack and all. A hyena had carried them off. He set a spring-gun, and though we found blood and hair, we did not get the carcase of our nocturnal visitor. 
Another night I had made a mining bucket of hide and left it at the mouth of the shaft. In the morning it had vanished to the lair of a hyena. The digestion of an ostrich is proverbial, but we could make reference equally well to this shaggy, steel-stomached marauder. Neumeyer shot a wild ostrich in this district about this time. Game was plentiful and up to now lions had not troubled us. We had built a very stout kraal for our oxen. As the days draw in we miss the little fox-terrier, for she had been a playful companion, and the diversion of watching the puppies grow had been denied us since they were kidnapped by the wily hyena. Roger Adcock also develops an antipathy for hawks. He had mended a favourite pipe by drawing a piece of hide over it obtained from the tail of a buck, and set it in the sunlight to dry and contract round the stem. A hawk swooped down in predatory flight and carried off the pipe. From that day Adcock's shot-gun was constantly employed in the reduction of these offal-lifters, and he heeds not to discourse that the hawk was a sacred bird to the Egyptian, and that Sam-of undoubted Eastern descent-might leave us on account of this sacrilege.

We had previously met in conclave and adopted Halkett's resolution to name the claims the "Mashonaland Main Reef". He put it to us in a very shrewd way asserting that it was 
what the country wanted, and we thanked him for supplying the name. Halkett and Neumeyer went to Hartley Hills and registered the Mashonaland Main Reef, and it got about the country that we had found the Main Reef, and from that day we had constant visitors. We might have done a deal at that time if Brand's thirty thousand pounds had not been too strongly impressed on us, and made us all too sanguine.

Christmas found us with a bare larder, and Sam and I spent the whole day hunting, but could come across no game on account of the grass-now over six feet high. The boy followed two honey birds during the day and on each occasion we were able to find honey. Those honey-combs are the only food we had that day, from sunrise to sunset, but on our return there was some cold chicken which Adcock had managed to trade.

Our conversation now mostly turned on Nowers and his arrival, but-like a good many othershe was detained by the rivers. Borrow had paid us a visit in November and told us we ought to come in to Salisbury, as we were in a bad fever district, but we were too wedded to the Mashonaland main reef, and it was the fact of sinking shafts in the rainy season and turning up the soil that gave us a very severe acquaintance with the malady; and the lack of nourishment, clothing and medicines that made our sufferings from fever 
worse that it should have been. Independent of that, malarial fever can be classified and that of the high-veldt is mild and that of the low-veldt very virulent. The weary wet season dragged $ı n$, and Halkett was our worst patient. Brand, Adcock and Neumeyer went to Salisbury to endeavour to get provisions and medicinethey bought a bag of Boer meal from Heaney for $£ 20$ - I remained behind to nurse Halkett. That was about the most miserable time I spent in Mashonaland or anywhere. My chum lay on his back with his mouth and lips black and the jaws so stiff that you could hardly get a spoon between his teeth. I often put a small handmirror to his mouth to trace breath, and as I had fever myself it was a drastic time, and mealiemeal gruel is all we could live on. One day a native runner arrived with a bag containing a bottle of champagne, a bottle of brandy, quinine, mazena and milk. It was from Borrow. He wrote saying that he had heard from Adcock that we despaired of pulling Halkett round, and he hoped that the native would reach us in time. He did. Borrow saved Halkett's life by that good deed, and the boy must not be forgotten for speeding to us. I gave Halkett the champagne in a spoon, little by little, and that day he sat, up and asked me what was up!

Finucane, Schermbrucker, Chiappini, Borcas and McLelland were all down at the time, and I 


\section{PIONEERS OF MASHONALAND.}

gave them quinine and a tablespoonful of brandy, including myself. These men were not in a serious condition; but it speaks well for them that nobody clamoured for medical comfort and tacitly approved that Halkett should have the lion's share of them.

Our comrades came back and brought Nowers who had arrived. We were thankful to get the provisions and medicines. He brought with him a Cape boy who had contracted fever on the way. Nothing could rally him and he died at Gedzena. Nowers could only tell us that his name was Jan. He lies buried on the claims of the Mashonaland Main Reef, that brought none of us luck except Neumeyer, who re-pegged claims here later and sold them well. 


\section{Chapter XVI.}

Lobengula's grace-50 per cent. dreams-Pioneers returning to Salisbury-Hospital-Dr. Tabitean-Dr. Brett-Early arrivals-Death of Louis Vintcent.

WE remained at Gedzena until late in February and no Matabele warriors descended on us to break the monotony. It is early in February that the Matabele have their big dance in the famous ox-kraal. Resplendent in their war-paint, ostrich plumes, shields and assegais, they demand from the Son of the Black Elephant where they are to dip their spears? Lobengula seizing an assegai would throw it in a certain direction, and, as the crow flies, the impis would set out and devastate, murder and plunder. The King threw no assegai this February of 1891, though his warriors looked expectantly to Mashonaland. Obviously Lobengula was the best friend we had, for dotted over the country as we were and fever-stricken, the massacre would have been easy. Did Rhodes want him to do it so that the British Government would have been bound to unseat him? The Police were, like us, also undergoing the ravages of fever.

Do Kaffirs get fever? Yes, they do, as the following will show. Lobengula allowed two 
impis to go to the Zambesi to divert their attention from us. He had a wonderful hold on his people, as Kaffir potentates generally have. These impis returned late in August, much reduced in number by fever, and a fight which they had had between themselves on the way, and the only excuse the indunas could make to Lobengula of this bloody affair was that fever had made them angry and they found themselves stabbing one another. As malarial fever affects the liver there is something in that, but many white men thought that this was the precursor of civil war amongst the Matabele. The idea being that Lobengula had either to wipe us out or find himself dethroned. He was a potentate that brooked no disagreement, and his executions made the nation proud of him. On this very delicate balance of the scales depended our existence, and tyrant as he was to his people he protected us from their murderous desires.

We were sorry to abandon our homestead, for we had built it well, and though we had the reef in our shaft to thirty feet she was disappointing, as she only had a width of nine inches; and for the Main Reef of the country her deportment was not dignified. Rich veins are the order of the gold-fields of this country, but rich veins will take all they can do to feed a five-stamp battery, and will not stand the Chartered Company's onus of 50 per cent. Mr. Rhodes' whole method of ex- 
ploiting this country was wrong. These goldfields ought to have been run on the Australian principle. The Government ought to have erected a five-stamp battery in each district at their expense, allowed the Pioneers and prospectors to bring their quartz, crushed it for them, and then they could have taken their $\mathbf{5 0}$ per cent.

Mr. Rhodes, dreaming at Groote Schuur, surrounded with luxury and wealth, thought we were discovering a Wittewaters-rand over again, that capital would pour into the country and the officials of his Company would be worried to death keeping check of the 50 per cent. streaming in like buckets of diamonds. The thin ox-waggon route from Kimberley to Salisbury had not brought in food, how was it going to bring machinery?

The Charter Company had started one thing by now and that was the pushing of the telegraph from Vryburg; but that is a long way off, and, though useful, the country needs a railway, and railways should come before development. The reason why the telegraph wire was pushed was because the Charter Company was losing too many men and horses in despatch-riding, and grumbled at the expenditure-the loss of life was a detail, and it was heavy both in men and horses, due to fever and horse-sickness, and the wire was to be the means by which Rhodes and Dr. Rutherford 


\section{PIONEERS OF MASHONALAND.}

Harris and Dr. Jameson could communicate, give orders and counter-orders.

At Hartley Hills Borrow had sent a waggon to take Pioneers to Salisbury, and sixteen of us started, all bad with fever. The first night at Hartley Hills a lion killed Taylor's horse. Taylor - a Pioneer-was then Mining Commissioner at Hartley Hills. This lion passed our waggon within a yard-his spoor up the kopje was easily traceable the next day, on account of the sodden condition of the ground. The cattle and donkeys scented him and caused much commotion. We heard Taylor shouting on the kopje and ran up with our rifles. His horse was dead, bitten through the neck. The lion had jumped in and jumped out of the kraal. It was Taylor who heard the horse's death neigh. The next day we found where the lion had crouched outside the kraal, after being driven off, as he had clawed the ground in rage. He had the sense not to take the odds, for there were ten men on the spot anxious to revenge the horse, and it was the darkness that gave him his chance of escape.

We left Hartley Hills the next day and outspanned about seven miles on the way to Salisbury. To do seven miles is quite a feat at this time of the year, for the country is so boggy that oxen sink up to their bellies and most of the time you must dig the wheels free. That night lions were constantly visiting us, and in the end, to- 
wards morning, they killed one of the oxen. We drove him off, found blood spoor the next day, but did not get his carcase. We cut the bullock up and the meat was welcome. By the way Heaney made very careful inquiries about that bullock. He seemed to imagine that we had shot the bullock as we were in want of meat. There must have been six or seven lions around the team that night, and the fires at the head of the team and near the front wheel kept them at bay, together with rifle shots wherever we heard a grunt or caught the glint of an eye. The bullock's hind-leg was broken above the knee-joint. I have mentioned the manner in which they attack a horse and a horned beast, and the difference is noteworthy. This trip brings out the many hardships of pioneer life, for the men are all fever-strirken, yet have to leave their blankets to drive off lions. The cattle, poor beasts, wallowing up to their bellies in black mud, plough a way to Salisbury; and in recalling the horse that was killed I must relate that it was a fine "salted" animal, who was able to withstand the ravages of horsesickness, only to be killed by a lion-we were all in it, the horse, the ox and the Pioneer.

When we got to Salisbury I was delirious and have but a dim recollection of going to hospital. My nearest fellow-patient was Dr. Brett and he was very bad. Dr. Tabiteau gave me two ounces of brandy daily, as he had a very limited amount. 


\section{PIONEERS OF MASHONALAND.}

I must have been run down. I recovered rapidly and was out before Dr. Brett. I met Spreckley in hospital, who was able to tell me that Louis Vintcent was up and about and had nursed the cases at Lomagundis. Father Hartman used to come in and he always had a surprise for the hospital. He worried Heaney until he got something for the patients, and most of the medical comforts were unearthed by him. He was scout for Dr. Tabiteau, and we raised a faint cheer when he came into hospital with condensed milk, mazena or brandy. Sometimes he brought chicken or eggs, which he had procured from Mashonas, and he had pickaninnis out to forage for the hospital. And what a fine fellow Dr. Tabiteau was! I saw much of him in these days, for he would come and sit on Brett's stretcher or mine and tell us the news. He went under himself finally and left Salisbury in August, and I was to meet him again under sad circumstances. It was in 1894 that two fine young Irishmen came to see me with a message from their brother, Dr. Tabiteau. I found him in the New Somerset Hospital, Capetown, cheerful and resigned, for, as a physician, he knew his case thoroughly well. He blamed the east wind on a trip across the North Sea to Rotterdam for playing havoc with his kidneys. I saw him frequently, and we generally spoke of the old Pioneer days, and one day one of his brothers fetched $\lambda$ priest and another fetched me. I got a grip of 
Tabby's hand before he cut the road we must all pioneer ourselves, and followed his funeral to the Catholic cemetery at Rondebosch.

Reverting to the Pioneers, Dr. Brett left Salisbury to take on duty at Victoria as medical officer for the B.S.A.C. Police after he came out of hospital. The huts that formed the hospital in the old days were close to the fort and police-camp. Many of the Pioneers were building themselves huts in Salisbury to convalesce here, for the hospital was altogether too small. Halkett, Judd, Adcock, Brand and others were camped at the Causeway, close to the English Church. Canon Balfour was living here, and we all helped to build the first church for the Church of England in these days. Pioneers started it and when they left Canon Balfour would ask others to do something to it and so the church of wattle and daub and straw slowly progressed; but in July, when I came up from Manicaland, it was yet halfthatched. I was one whom Canon Balfour coaxed into putting some work on this roof. By the time the Bishop of Mashonaland, Knight Bruce, arrived, there was a very substantial and imposing church erected, when compared with the other edifices of its environment.

One of the first to get through to Salisbury, before the Lundi cut so many private waggons off from reaching us, was a French count, who was coining money by selling whisky at $£ 5$ a bottle. 


\section{PIONEERS OF MASHONALAND.}

With him was Billy, and Billy was a woman dressed in jaunty knickerbockers. The old Count was very anxious to sell whisky to anybody. but waxed exceedingly wrath when Billy spoke to somebody. The administrator did not approve of his villainous charges, nor of the moral tone to our budding town; and the Count betook himself, his Billy and waggon to the Mazoe valley. I never went near this exorbitant trader; but some time after I went to the Mazoe, where many of our Pioneers were camped; I met the Warrens, the Walkers and Pattinson again. They told me that prices had come down to $£ 3$ a bottle and that men made trips out to his waggon. Billy they considered pleasant to talk to, but the old Count was a Bombastes Furioso. I had a very bad relapse at the Warrens' hut, and fortunately our administrator and Bob Jameson passed in a cart on their way from Lomagundis. I was surprised to wake from my delirium to see Bob Jameson sitting at the side of the stretcher. He gave me whisky and quinine, and told me that Colquhoun had left it for me, and that he had gone on, but Bob had found me so bad that he decided to stop the night. It was here that I heard of Louis Vintcent's death, and Colquhoun and Jameson had driven out to Lomagundis to fetch him in, but my old friend the Mining Commissioner of Lomagundis had succumbed. When one has become very exhausted with malarial fever the fainting comes on one at. 
intervals of every five minutes : that is how Bob found me. Louis must have gone when a stimulant would have strengthened the heart and pulled him round, and this quinine and whisky that had been given me had been meant for him. I had not seen Louis since the days of disbandment, but I can recall his happy laughing face vividly now. It is a very beautiful place this Mazoe valley, with undulating hills and fine woods. At the Mazoe river lemons grow abundantly, and whether these were planted by seventeenth century Portuguese, or the Arabians who were here before Aryan races had become civilised in Gaul, Germania or Albion, I cannot tell.

The country is thickly populated with natives who cultivate extensively, and settlers are farming there to-day with good results.

I came down from the Mazoe valley to Salisbury and found Major Forbes busy enlisting Pioneers for Manicaland. I had consulted him as to going up to Tette and fetching provisions with donkeys, for Salisbury was in a famine, but he smiled a grim smile, this bull-dog Englishman, and spoke of Portuguese gaols. It is a very fine trip to the Zambesi via the Mazoe and the Ruia Rivers, but a Portuguese gaol is not the most delightful finish. 


\section{Chapter XVII.}

The Chartered Company and transport-Manicaland-Gorweia and d'Audrada-Prospector's idea of the Foreign OfficeMassikessi-Pioneers as traders.

Bidping adieu to the Excelsior Syndicate we take up concurrent events from Chapter XIII.

Extravagant reports of alluvial and rich gold reefs were the order of the day. Old workings were eagerly sought for, and in that way many a Mashona rice-field was pegged off. Rushes, stark, staring mad rushes possessed the Pioneers and prospectors. As far as that goes, if for the moment we imagine everybody mad and by no means regard the Chartered Company officials as keepers, but as the chief lunatics of the country, then we will better understand the situation.

We parted with Jameson and Johnson going to explore a route through Portuguese territory. One would imagine that after coming up the Pioneer road-now called the Selous road-and knowing the difficulties of the country between Tuli and Victoria, and that in the rainy season the 'Msingwani, the Nuanetsi, the Lundi and the Tokwe would be impassable, that boats would have been placed on these rivers and transport hurried on. To get your expedition into a country is the 
preliminary, to maintain your transport and keep. them supplied with food is the most important step. No waggons were coming up after us apparently, but as we had faith in the Chartered. Company we thought they would arrive eventually before the rainy season.

Jameson and Johnson passed through Manicaland to Massikessi, must have noticed that the Portuguese live in comparative comfort, and that. they were supplied by no transport service consisting of cattle, but by native bearers. On enquiry they would have been told that from Chimois to Saramento was a long belt of the deadly tsetse-fly, and that would have warned them as to cattle transport. We will come back to them.

Meanwhile it is sufficient to remark that they got to Beira and Capetown, and advertised the occupied hinterland.

Mr. Colquhoun, relieved of the meddlesome physician, caught the germ of insanity rapidly at the official residence-a kaffir hut. It appears the Administrator and Lieut.-Colonel F'ennefather quarrelled over the settling of Manicaland, and the O.C. went down the Selous road and Colquhoun did without him. Selous had gained a treaty from Umtasa, the paramount chief of Manicaland; but Gonveia, the Portuguese representative, regarded himself as governor of this same territory. Gonveia had gone to Umtasa. 


\section{PIONEERS OF MASHONALAND.}

with Colonel d'Andrada and threatened him, obviously to get him to revoke his treaty; but was surprised by Captain Forbes and some troopers of "B" Troop of the B.S.A.C. Police and promptly made prisoners. He sent them as prisoners to Fort Salisbury, and the Administrator, averse to their company, forwarded them with their escort, Lieutenant Mundell, to Sir Henry Loch at Capetown-you are acquainted with the length of that journey.

When they were released at Capetown, not only had Colquhoun got rid of their presence in the country for a considerable period, but he had also impressed Umtasa with the power of the Chartered Company, for Gonveia had raided and terrified these natives for the last twenty years with consistent cruelty.

General Gonveia and Colonel d'Andrada went to Portugal and aired their grievances. Previously by an Anglo-Portuguese agreement arrangements had been made to establish a route from Beira and to build a railway. This arrest was a first step to alienate Portuguese assistance, and as we had to pass through their country to build that railway, and it was of vital importance to us, this move was decidedly undiplomatic.

Selous was engaged to make a road to the Pungwe River, and Messrs. Johnson, Heaney and Borrow sent an enormous convoy of waggons and oxen down to Saramento via Chimois, through the deadly belt of tsetse-fly. 
Meanwhile Dr. Jameson announced that sternwheelers would soon be steaming up the Pungwe, and Johnson advertised the fact that the route was open for passengers and mails. The result of this advertisement was that people flocked to Beira to get the Eldorado, and had to go home again because Heaney and Borrow's waggons are lying about the roadside to this day, and the carcases of thousands of oxen. Johnson got two coaches, brand-new American ones, shipped to Saramento, and they are also there by the wayside. The sane manner of opening a country is to build your railway and development follows; that is what Canada and America have done. You have just perused one of our highly neurotic ways of opening a country, but we were not singular in our madness, for a few months later we are surprised to hear that the Portuguese have sent a gunboat up the Pungwe and landed troops.

The explored route had fizzled out; there was no attempt to organise a band of carriers either by Messrs. Johnson, Heaney and Borrow or the Chartered Company. Half-a-dozen elephants obtained from India would have transported goods through the fly-belt, and waggons and oxen could have taken up the work from the uninfested quarter up-country.

The loss of these waggons and oxen resulted in Messrs. Johnson, Heaney and Borrow calling in all waggons and oxen from the Pioneers. The 


\section{PIONEERS OF MASHONALAND.}

Pioneers had now no means of ploughing, nor of conveyance of food stuffs to their camps. The encouragement of agriculture was not thought necessary-get the gold!-Mashonalanders are now quite oblivious of the menace of Lobengula behind them, but are confronted with the attitude of the Portuguese-gunboat and soldiers sent from Delagoa Bay to Beira-and as the rainy season has set in the belligerents are nursing their bellicose intentions.

Shortly after this Sir Henry Loch and Mr. Rhodes left for England to interview Lord Salisbury, and as the Prime Minister had stated in July last that he knew of no armed force proceeding to Mashonaland to the Portuguese ambassador, and since then-six months-we had not only proceeded to a destination named after him, but had succeeded in convincing the Portuguese that we meant to sprawl our limbs, as a cramped position was unconstitutional with us; we were anxious to know whether the Prime Minister would repudiate us or stake his claim with us.

As there is no record of the interview of the Prime Minister, the Governor, and the Managing Director of the Chartered Company, I must give you the opinion of one of our prospectors :-

"Lord Salisbury," said he, "ain't got no use fur gawgraphy, bein' a Furrain Minister. Rhodes looks upon this here country as a blank cheque that wants fillin' in, and he don't want it crossed 
to any other party. He wants to get his signature to it, and it must be made out to the order of the Charter Company. Sir 'Enery, he lays a map afore Lord Salisbury and says he, "There are hintricacies.'

“' 'Dear me, dear me,' says Lord Salisbury, ' define the boundaries.'

" There ain't no boundaries to the Hinterland,' says Rhodes.

" 'I concur,' says Sir 'Enery."

We are all politicians or patients now, and the gold-fever has been supplanted by malarial fever, and the Pioneers find January, 1891, open for them with bitter earnestness: and mad enthusiasm is replaced by deliriousness and dysentery, and the havoc amongst these brawny men is severe; for want of nourishment and lack of medicines, and which were unprocurable for gold, all the gold that yet lay hid. The Main Reefs that are to eclipse Wittewatersrand are opened up to some-they do not return to tell us where lies fortune. Others are found lying at the base of an old working waiting for the honey-bird to chirp "sesame," when the ground opens and discloses Assyrian nobles feasting with Rhodes and Jameson, and dividing the 50 per cent.; whilst he, poor slave, is pounding quinine on a granite mortar, that runs away into quicksilver and mixes with the curls in the beard of his taskmaster. 


\section{PIONEERS OF MASHONALAND.}

The lash descends upon his shoulders and he awakes to kiss the lily hand-of a Pioneer chum.

"Better now, old man; fight the damned thing like hell, don't give in. Drink this, it's a little weak tea I've saved. There is nothing else but mealie-meal, beans and Kaffir corn, and that would kill you, with your stomach rotted as it is. Courage, old man, until I can get you into Salisbury. Curse the money-grubbing set of company promoters who run this country. What is the life of man or horse to them? Go and ask the Police who sleep between Nuanetsi and Lundi and the Pioneers who-steady, old man, don't give in."

The other fainted and came round, saying :-

"All right, old man, don't take on so about the Company; after all they represent the Old Country."

"Aye, there's the rub."

"After all they have a difficult task. They have not done fair by us, yet if they want men to-morrow we would see them through."

"That is so, more fools we."

The Chartered Company were soon wanting men, for the Portuguese were advancing to Massikessi.

Captain Heyman with forty men, "B" Troop, and a seven-pounder had removed from Charter early in February and taken up a position opposite Massikessi. The Portuguese bade him retire. Captain Heyman replied that his orders were to hold his position. The Portuguese 
advanced to the attack and Heyman opened fire with the seven-pounder and volley-firing. The affair was soon over, for although the Portuguese officers showed splendid courage, the motley crew they commanded broke into a run and disappeared out of the country. Captain Heyman follower up his success by occupying Massikessi.

The twenty-pounders-facetiously so called by their fellow Pioneers-were a body of Pioneers who hastened to support Captain Heyman, under the command of Mr. Selous, but were too late for the fight and the loot. Captain Heyman did not invite us to help collect together Portuguese goods at Massikessi. The Police brought to Umtali nine machine guns-from which the pins had been extracted by the Portuguese-and 110,000 rounds of ammunition. Cosy arm-chairs took the place of biscuit boxes in the officers' mess, and the Police swaggeringly vaunted to the thirsty Pioneers of the virtues of vino tinto. A large stock of tinned provisions were captured by the Police which was worth its weight in gold to the starved and fever-stricken B.S.A.C. Police. There was a general impression that we would follow on and pay the Portuguese an inamicable visit at Beira, but our intellectual administrator had a conscience, which his literary capacity helped him to keep alive, and he ordered Heyman back from Massikessi, and as the Portuguese had been here since the seventeenth century, one can- 


\section{PIONEERS OF MASHONALAND.}

not blame him, but, to use prospecting parlance, the Chartered Company had effectually "jumped" the claims of Manicaland. Shortly after this, surveyors were sent out and the Portuguese boundary defined between Massikessi and Umtali.

The result of the fracas is felt by the Pioneers - pioneering seems to be the hell that savants find difficulty in defining-for the Portuguese close the East trade route.

Immediately they were on better terms in a sense-for our methods were not conducive to friendship. You cannot go into a restaurant and eat a man's dinner and expect him to shake hands with you over the event-the Pioneers became traders and brought up goods from Beira carried by native bearers.

I have before stated that these men ought to have been supported by the Chartered Company, in that they should have guaranteed payment to the bearers or established a train of men, and allotted them to the traders. Let us see what happened. A Pioneer on walking down to Beira. would purchase goods for cash and proceed to collect bearers. He would offer these boys $\mathfrak{2 2}$ a head and they would seize the opportunity. A Portuguese official would demand payment in advance-presumably in the interests of the native, obviously because he was a member of The Filibuster Company, which is Portuguese for Charter Company-the Pioneer was obliged to. 
pay out. If he was lucky in coaxing them to Umtali his profits were great, but more often than not, they carried for a day, or two, or three or four, according to when the mutinous fit seized them, and left him in the lurch. The Pioneer and his goods were stranded on the veldt, and as he was weak with fever would struggle back to Beira where the Portuguese official would shrug his shoulders and give him no redressperhaps he found consolation in the Pioneer's discomfiture and regarded him in the same light as Rhodes-means to an end.

The Chartered Company-with their usual carelessness of the welfare of the individualdid nothing for him. Yet this material was the backbone of the country and time after time individual initiative was thwarted.

In later years somebody pegged off the Victoria Falls and the Chartered Company woke up, would not register his claims, and declared the country twenty-five miles round the Falls as their own prescriptive right. By what authority? Nothing but sheer arrogance. 


\section{Chapter XVIII.}

Five points against developmert-Umtasi-Return to Salisbury -Young Colquhoun.

When Captain Forbes was enlisting the twenty-pounders I managed to get as far as the Police quarters when ague came on me and young Bly-son of Capt. Bly-a trooper of “ B" Troop, took me to his bed and made me comfortable. I sent him to tell Forbes and Selous I was with them, but could not appear to sign on. I can never forget Mr. Selous' kindness to me on the way down, for he gave me his bed in his waggon, doctored me with Warburg's Tincture and fed me on milk, bread and butter. The good man had his own cows with him and made his own butter. He would talk to me a while and bid me go to sleep. I was able to tell him of the carcases of five elephants I had passed in my wanderings around Gedsema and he smilingly announced' that he had shot them in that vicinity some years previous. I learnt from him also that Dr. Sommerchiels had received a rough reception at Delagoa Bay from the Portuguese on account of our strained relations with that nation, and because he was a British subject and to hand for vindictive display. 
Selous left us in Manicaland and went back to his road-making after Heyman's adventure. The Pioneers were still held in reserve, but employed their time in prospecting. We divided into small parties and Colquhoun, Watney and I built a hut about a mile from the Umtali Camp. We three were fortunate in procuring a good boy who told us much of Gonveia and the Portuguese. In this country we were able to get from the natives a species of flammable rubber that served as a candle. Up to now we had been forced to go to bed when the sunlight gave out. Soap-the blue mottled kind-I bought from a B.S.A.C. trooper at ten shillings a bar and we revelled in its blissful lather.

I got our boy to wash out our kit, and he did it very well. A particularly favourite pair of "duck" trousers of mine he turned out in spotless cleanliness, and I put them away for state occasions. The winds were very cold on the hills here and I distinctly remember the trouble I had with neuralgia. Some of our men found good results here and we listened to the usual enthusiasm. It was with a dull ear now, though, for we had gradually become wise to the knowledge that the gold-fields were at a disadvantage : (a) there was no run of reef in the country that could support a large community as in Johannesberg; $(b)$ the lack of an efficient transport and the excessive rates; $(c)$ no railways; $(d)$ the 


\section{PIONEERS OF MASHONALAND.}

Ancients had been here for a considerable period, worked on an extensive scale and left little behind. Their organisation-no matter whether slavery was employed-was superior to ours and therefore gave better results; $(e)$ Lobengula. So when a man waxed eloquent you told him to go and sit on his claims and, perhaps, as a greybeard he might realise something-even if it was the experience that gold-seeking was in the white elephant category.

Colquhoun, Watney and I decided to go and visit Umtasa, and do a little trading with him. We took our boy with us as interpreter and walked to his stadt. We climbed up the mountain, passing up a single path, twisting in all directions through endless kraals, until we got to the stadt. We did not see the chief, his son sent us red millet on a platter and a message to the effect he would see us later It occurred to me to wear my white "ducks" ostensibly as a court uniform, and I agreed with my comrades that I should conduct the indaba through our interpreter. Umtasa's son announced that he would be pleased to see us and we followed his messenger. He was lying back, indolently poking his elbows into the bodies of his Indunas who patiently acted as supports. A cheeky looking native, I should say about twenty-five years, was this son of Umtasa. He said his father was ill and could see nobody-that was a lie, we knew 
he had got tired of our visits. I told him I was a great white chief and come to do a little trading with him for his own benefit. I do not know if that was wise, for on displaying our goods he offered two head of cattle. I asked to see the animals and they drove up two skinny calves. That was absurd. I had observed that the son of Umtasa kept his admiring gaze on my "ducks" and deemed it etiquette to ignore the fact. To my amazement, he gave out that if I would trade the "ducks" he would add another head. Colquhoun and Watney burst out laughing and I ended the indaba by telling him to go to--!

After two months in Manicaland the twentypounders were informed by Captain Heyman that their services were no longer required, and that Captain Forbes would pay them at Salisbury, which is a distance of 190 miles from Umtali. They had to walk that distance carrying their blankets and rations, rifle and ammunition, and they did it. The circumstance only enhances the grit of the men. If you doubt it, pack yourself with 50 lbs. weight and walk twenty-five miles, and let me know how long you keep it up. You have the advantage of a bed to sleep in, no lions to attack you and keep you on the qui vive, nor malarial fever-which is intermittent-to harass you.

At one of our halts for a meal, fever attacked me and I decided to let my companions go on, 


\section{PIONEERS OF MASHONALAND.}

and rest. Colquhoun anticipates me and says he will stop with me. I did not bargain for that, and scheme to be left alone. We must have done ninety miles of our journey and had a hundred miles to do yet, and I was seeking strength and did not want my companion to lose the opportunity of travelling with the others, for the lions are very venturesome on this road and had attacked a despatch-rider lately. He sits by my side and I see his handsome, refined face now. Smooth and oval, rosy as a girl's, and expressive grey eyes. I make an effort, pack my bundle, and trudge on. I tell him to hurry on and I would catch them up at night-fall. He goes ahead and at a turn of the road he is looking back for me. I make that turn, determined to deceive him, and pretend to be jaunty, and at the next turning choose a spot and spread my blankets and let the ague and sweating take their course and fall into a glorious sleep, oblivious of dangers around me. I woke the next morning and must have slept twelve hours at least, and trudged along merrily until midday. It dawned on me the others were well ahead-never mind, I had had that sleep. I cooked my billy and rested until sundown. I walked all that night, and early in the morning I came upon my comrades around Selous' waggon. Colquhoun reproached me, and I laughed at his upbraiding. but nevertheless cherished it. It appears he only 
caught up the others at night-fall and had made certain I would come on.

Armstrong was working with Selous at this time, and he told me of some lion-shooting Selous had done after he left us. Those are the lions that attacked their grass hut and Selous shot three by poking the rifle through the grass, feeling them and firing. He has written this incident, but $I$ had it at this time from Armstrong who was with him. Mr. Selous had a Reading newspaper with him and read out to me an account of my brother George's wedding. Selous came from Wargrave, and the Darters held considerable estate there at one time. It is possible that the roving spirit in us both, is due to the Norman blood we had inherited. What is more to the point, he regaled us all with eland, which he had lately shot, and we had a kingly feast.

We rested here for the day and did not set out until the following morning to our destination, Salisbury, some fifty miles ahead. The return of the twenty-pounders caused quite a little commotion, and the towns-people-we are getting on now with Salisbury-turned out to greet us and have a gossip. We will look round Salisbury presently and note its improvements. I want you just to take a last glance at Manicaland. 


\section{Chapter XIX.}

The Sabi and early Arabians-Blended races-MonopotamaEarly Portuguese - "Monty" Bowden-Milestones of British pluck-Salisbury's growth-First English church -Mother Patrick-First baby-Cecilia-Matabele sayings.

THE country between Salisbury and Umtali is a beautiful high table-land, and splendidly adapted for arable and pasture lands, well wooded, well-watered and dotted over with the inevitable granite kopjes. It is a country thickly, populated by natives. From the Nyanger Pass the country drops rapidly and the waters drain into the Odzi, a rapid-running stream which again runs into the Sabi. This fertile basin runs right through Portuguese East Africa, and Mr. Theodore Bent traces Sabi to Sabæa. The venerable and time-honoured Sabi brought the lowprowed Arabian galleys to the country and departed with the gold, ivory, lions, giraffes, cephalous apes, and slaves, with which the Queen of Yemen or Sabra paid tribute to the Assyrians. We are not to suppose that they could embark giraffes, cephalous apes, and lions in any quantity in ships that had to carry a big cargo of galley-slaves, but as the Phœnicians had a trade route from the shores of the Baltic to the 
shores of the Mediterranean, it is correct to suppose that a kindred race of Arabians, who were the merchants of the world of the East, set out from Sabæa or Yemen, and had overland routes in this country, in Somaliland, in Abyssinia, and that they employed the elephant and dromedary largely for transport. Every schoolboy knows how the troops of Hannibal terrified the Romans with elephants and black horsemen, and when one is acquainted with the Arabian proverb, "blessed is the country that has no history" the difficulties before Mr. Theodore Bent appears to be insurmountable, but when you read his "Ruined Cities of Mashonaland" you will admit he has made out a good case, and one can only anathematise this mysterious race for leaving no records. Highly civilised from a commercial aspect, for they understood transport better than the Chartered Company, barbaric in heathen rites of which human sacrifice played its part. It is interesting to note the slaughter of children amongst the Carthaginians, and that they were roasted in a brazen bull, and that the Mashonas to this day sacrifice twins by roasting them in a pot, and one recalls the "hot-potting" which Mr. Rider Haggard adopts in "King Solomon's Mines." Do not speak of King Solomon before Mr. Bent because he will despise you as a hankerer after modernity, because the Semitic race from which the Jews sprung were 
brick-makers to Thutmes II, the Pharaoh of the times, and their Phœnician leader, Moses, led them back to Yemen, Sabæa or Canaan-the same country. The monotheistic stage of these Semites is the story of the Bible, we find them breaking out in idolatory, and we read of Abraham sacrificing his son and then substituting a kid. Mr. Theodore Bent shows us an instance of goat sacrifice amongst the Mashonas

The colour question at once attracts us and we endeavour to analyse the obliteration of white men. Thutmes II overran Egypt and was an Ethiopian. He upset the Phœnician dynasty. Now when we consider the customs of polygamy and slavery, the introduction of black blood is at once grasped, and its spread understood amongst the Egyptians. This Thutmes was an Abyssinian, and, as the Zulus or Abantu stock come originally from this country, we would have a better picture, for the sake of illustration, if Lobengula had deported the Pioneers to Buluwayo, held us in bondage and allowed us black wives, the children to-day of the Pioneer stock, twenty-five years afterwards would have been an interesting study of the obliteration of the white race, but, as that did not happen, I must give you an object lesson that Mashonaland could supply in these Pioneer days. It is Gonveia, who was made prisoner, himself a half-caste, native of Goa. The Portuguese mixed freely with the 
natives and took many mistresses, and the children of Portuguese possessions are not of the white race, nor are they denoted for advancement or refinement. Base cohabitation, polygamy and slavery go to produce an inferior people, and centuries later, the Abantu warriors "wiped out" the men and took unto themselves their wives and children. Sabæa itself was unable to keep in touch with her provinces, for that country has been over-run in turn by the Assyrian. Egyptian, and Persian. As to a people who call themselves Sabæans to-day, they are Arabians who became followers of John the Baptist and were spared by Mahomet, and are mentioned in the Koran to be tolerated by the followers of the Prophet.

Mecca is in Arabia Yemen to-day, and every Mohammedan desires to see the Kaaba stone in the mosque of that city, and to come back a hadji entitled to the green turban. Where Mohammedans flock to-day the old Arabians set out from to explore and exploit Africa and India, and the Kaaba stone of their Marieba which is the Kaaba of Mecca to-day has antiquity greater than Zimbabye, for it belongs to the age of stoneworship, astrology, and other customs that gave to Mashonaland its first people and its first worship as far as we can trace. Mr. Theodore Bent, in referring to the unsatisfactory writings of Portuguese of the seventeenth century, points out that they had the same failings as Herodotus 


\section{PIONEERS OF MASHONALAND.}

in that their stories are largely hearsay evidence from Arabian traders of that century. The word Monopotama like Pharaoh and Chibi, denotes Paramount Chief or Emperor, and the Monopotama of the seventeenth century was a potentate of Abantu race, holding sway from this country to the Zambesi. The Barotse, the Makalaka and the Basuto are descendants of this race. Mr. Theodore Bent also found many bushmen drawings in the country. Some of these I have seen for myself, but who taught these little fellows to mix their colours, and just when they came into this country and when they left it is one of the land's many mysteries. When did they leave Europe? There are traces of them in the Pyrenees.

Mr. Theodore Bent arrived in Mashonaland and was pursuing the work of excavation at Zimbabye in June, and left by the Beira route in November. The result of his labours has thrown much light on this sealed book. Later, Mr. Mac Iver wrote a book to the extent that these ruins were solely the work of Kaffir races, but just exactly what the Kaffir is himself, and where he got his oriental ideas from, wants defining. There are statements that negroid races occupied parts of Europe.

I once shot a crocodile in Matabeleland-on land-and could not get a native to skin him. They regarded the act as unholy. I understood 
the crocodile's wandering on the veldt, because the river was dry in places, and he was taking a short cut from one pool to another on account of the big bend in the river-course, but I could not grasp the Kaffirs reverence for this pest, except that the Egyptians venerated the crocodile, and these Kaffirs are the descendants of men who came from the north, who knew Egypt, or whose forefathers had learnt her customs, as their descendants are to-day following ours. When, however, we come to building temples or houses, we trace no architectural skill in these Kaffirs. Had they possessed the knowledge they would have developed it, and we would have met stone houses and kraals all over South Africa, and not wattle and daub huts.

Is it not more likely that a virile and barbaric Kaffir race descended on an effete civilization amongst them, and wiped it out, and is it not the most important problem to-day that the white races must guard against their being swamped by the native? Should that occur, five thousand years hence, somebody might write a treatise to the effect that the Kaffirs built "Groote Schuur" and Rhodes was their Monopotama.

It is with reluctance that I break away from the Arabian founders of Mashonaland, whose mother-country paid tribute to Cyrus, and return to the Pioneers whose mother-country pays homage to Rhodes. The founders and Pioneers 


\section{PIONEERS OF MASHONALAND.}

are overlooked in the glamour that surrounds a potentate. The Pioneers, like the Arabian founders, turn traders and it must be notedin passing on-that in this country Father Silviera met his death in the seventeenth century, and that to Massikessi belongs a civilization of a time when Portugal was in the zenith of her glory. The track that was trodden from the coast by the Arab and Portuguese was re-opened by Pioneers, prominent amongst them was the young English cricketer, Montague Bowden, who started a store in Umtali, and supplied it by marching from Fontesville to Umtali, with goods carried on the heads of natives. Many other Pioneers gave up the search of gold for trade, but Bowden stuck it manfully until the fevers of the low-lying country of the Pungwe route killed him. Mr. Rhodes came this route in October, on horseback, and found "Monty" struggling with life and death on his way to Umtali. Rhodes gave him a bottle of whisky and a horse to continue his journey. Monty managed to get to Umtali, and the mercy of woman's gentle ministration was accorded him, for Sister Blenherhasset tended him. These sisters came to Umtali with Bishop Knight Bruce early in July, and worked in the Umtali hospital under Dr. Lichfield, who was one of our Pioneers. To-day, many ride by train from Beira to 'Mtali, but recollect the route as Monty followed it, not as 
the Portuguese did before him in a bier slung on native shoulders, not on a camel as the Arabs did before them, but on foot, and the name of Montague Bowden is the milestone by which I measure the British pluck of my old comrades, and at Massikessi the other milestone is Alick Halkett who was crushed by a waggon a few years later, and the next milestone is in the Pungwe vicinity where Beaumont, a prospector, was killed by a lion whilst walking behind his companions, and the last milestone, Joe Aldridge, who waited for a buffalo to charge before he shot him, and here, one day, he waited too long. Dare devil, yes, but a milestone of British pluck.

Having marked these milestones and remembering the Pioneers whose lives form the pillars on which the history of these times should rest its foundation, we recall the day, September 14th, 1890, two days after their arrival, when the Pioneers hoisted the Union Jack, saluted the emblem of the British Empire, and named the place Salisbury. This Salisbury, what was it like in July, 1891 ?

It boasted an hotel and sold whisky and soda at ten shillings and sixpence. Four drinks would probably kill you, and you would have spent-independent of life-the fee of a British specialist. It was a building of poles, mud, and grass, and had for its manager, Stewart-the Pioneer who was lost with me for three days. 


\section{PIONEERS OF MASHONALAND.}

He told me that Gascoigne had floated an hotel company. The shares were taken up by the B.S.A.C. officers. The capital was $£ 5,000$, and the shares £25. It stood on the Causeway side, between the police-camp and the primitive Church of England. Salisbury was divided into two parts. All the huts near the fort were known as the Causeway, and across a marsh, about halfa-mile, nestling under a small kopje, were more huts. Here was Johnson, Heaney \& Borrow's quarters. In the early days some of the Pioneers built huts this side, as others did at the Causeway.

Salisbury was occasionally visited by lions in these days. I allude to the town itself. Johnson \& Co.'s horse-farm, only two miles from the town, was frequently the subject of attention of these beasts. We were surprised one night by a lion roaring as it crossed the marsh, between the kopje and the Causeway, and not long after a man was brought into hospital suffering from a crunched shoulder. An old lioness had pulled him down about three hundred yards from the kopje, as he came into Salisbury driving his team. Whilst his father was being mauled, a lad of fourteen managed to get the rifle from the waggon and shot the lioness.

Mother Patrick, at the head of half-a-dozen Catholic sisters, have reinforced the hospital, and many a man blesses their advent. Father 
Prestige came up with them and he is to be seen in company with Father Hartman. Father Prestige and these six Catholic sisters were at Macloutsi Police camp at the time that we were at Tuli. They have nursed the police at the base with such a tender welfare that their fame has preceded them, and we all love them. They have been greatly distressed, for at Umzingwane they lost a policeman, Van Dencken, who was found forty-seven days afterwards in an ant-bear hole by some Dutchmen. This poor chap had lived on roots and his hands were bare to the bone. I think he just lived to see the sweet faces of these sisters. I related our experience of three days and three nights, so Van Dencken's feat is a record. We had no sweet good face to cheer us and none to pray for us. The only face I saw was a hyena's and that don't make for good prayer. The first Bishop of Mashonaland is with Canon Balfour, but as he is a great walker, he will be off very soon, for Knight Bruce was in Mashonaland before the Pioneer expedition. Our first Bishop gave a Pioneer a pair of boots, which was more valuable than a gold mine, for in these days we were shockingly in want of clothing. Schermbrucker, Wyatt and others have started as auctioneers and goods coming up are sold at fabulous prices. Candles are sold for a sovereign a packet, and the man with a candle hires it out to gamblers, who give him a percentage from the 
pool. Soap is a sovereign a bar, and a coat, boots or trousers worth a five pound note.

Quite a sprinkling of settlers have pushed their way into the country.

About this time we had our first birth, for Mary, the wife of a prospector, brought a little girl into the world, and she was baptised Cecilia in honour of Cecil Rhodes. The Pioneers were intensely excited over this event, and some of them lost money over it because they were backing Billy to win the race. Before paying their stakes they took a trip to the Mazoe to satisfy their thirst for knowledge on the subject, and returned to find that Billy had lost by a head. These two women deserve a special mention, not only for the children they brought us, but for their pluck in facing the perils of the settlers in conjunction with the cares of maternity.

At the kopje is the searchlight we brought with us, and we learn in these early days that we owe our salvation from attack to the light. The Matabele had seen it and exclaimed that "we had brought down fire from the heavens to destroy them."

I think it was James Dawson who brought us this intelligence and I should have mentioned before that he came into Mashonaland in October, 1890 , to prospect and peg claims for Lobengula.

Apropos of the Matabele and quaint sayings, some Matabele Indunas were talking to Sam 


\section{PIONEERS OF MASHONALAND. 167}

Edwards at Tati about the telegraph which had reached Palapye at the time. "You white men are bringing up wire to tie up our king," said they. 


\section{Chapter XX.}

Vorster-Adendorff trek-Dr. Jameson-“Doul" Zeedenberg -Colonel Ferreira.

HARDLY had the Portuguese affairs at Massikessi subsided when the Charter Company found itself busy in facing a Boer demonstration, on the Crocodile river, engineered by Messrs. Berend, Vorster and Louis Adendorff and led by Col. Ferreira. Imagine the Boers drawn up in laager on one side of the Crocodile and the B.S.A.C. Police throwing up earthworks and mounting maxims at the drifts - of which there are threeand as this takes time it will be advantageous to take up the thread of events, at our base, Tuli, leading to this and to other occurrences.

It will be remembered Dr. Jameson and Johnson left via Beira, and Colonel Pennefather came down the Selous road from Salisbury to Tuli, and saw Mr. Rhodes here and got leave to go to Natal. Further that Mr. Colquhoun, Major Forbes and Captain Heyman managed Manicaland troubles in his absence. As far as Colonel Pennefather is concerned, it is enough to say that the history of the country now is not connected with his name, although he was O.C. for some months after, later he resigned and left the coun- 
try. He seems to have had his grievances-there is no space to ventilate them here, for there are many others. Mr. Rhodes and Sir Henry Loch arrived in October, 1890, dined with the officers of the B.S.A.C. Police, and, as the rains were heavy, the rivers in consequence would become swollen and fever rife, Rhodes was persuaded to return to the Cape. Sir Henry Loch retraced his steps through Bechuanaland, Cecil Rhodes went back via the Transvaal. At Pietersberg, Berend Vorster and Louis Adendorff asserted that they had a concession from Chibi and that they were willing to sell it to him. Rhodes did not commit himself, but assented that if they would submit their claims to him he would see what they were worth. As you have already read of Selous' visit to Chibi and his treaty with him, when the Pioneer column was at the Lundi early in August, 1890, that Chibi acknowledged Lobengula's supremacy, therefore Chibi could not grant rights to any white man without Lobengula's sanction, without incurring the potentate's grim ire. To impress that fact on you, in 1892 Chibi thought he was safe enough, with the white men in the country, to refuse the tribute due to Lobengula. The Matabele descended on Chibi's kraal, killed him and every adult man of his stadt, razed it to the ground, and carried off the women, children and cattle. Before he became Chibi-which is head chief-his brother, who was 
the Chibi before him, had offended Lobengula and had been carried off to Buluwayo and flayed alive. Now, having got those facts into line: you will understand the position, and readily see that the Vorster-Adendorff proposition-I cannot call it a claim where no claim exists-was based on bluff, and that as Mr. Rhodes did not bite-I cannot say buy, seeing there was nothing to buythis demonstration on the Crocodile in April was meant to force the millionaire's hand.

It is about time now to find Jameson, and he is here taking rides from Tuli to the drifts, and watching the situation. He knows perfectly well that the Charter Company hold the cards, but he is anxious whether they will ignore the rules of the game and endeavour to scoop the pool by an invasion.

Where has he been all this time?

He came to Tuli in December, after Rhodes had left, took a body of B.S.A. Police with him and rode to Portuguese East Africa. He left the troopers at a point, and taking the ubiquitous Dennis Doyle with him, travelled through Gazaland. This occured after the capture of Gonveia and d'Andrada in November, and at a time when the Portuguese had sent a gunboat and troops to Beira. Obviously, this was a reconnoitring trip to ascertain what troops Portugal had at her disposal in Portuguese East Africa. He returned to Tuli in April, when owing to the Chartered 
Company having pursued a policy of economy, their troops are not only short-manned, but many men are down with fever. " $\mathrm{C}$ " Troop has been ordered to concentrate on Chibi's, and they are stationed at Victoria. I have alluded to the old hunters' road along the Nuanetsi down to the Crocodile. "C" Troop would patrol this route and check any advance in case the Boers force the top drift. Troopers of the Bechuanaland Border Police are despatched to reinforce the B.S.A.C. Police at the drifts, and Sir Frederick Carrington is appointed in command. The Boers have not attempted to cross the Crocodile, and as their country around the river abounds with game it is nothing unusual for them to be in this part at this time of the year. I advance this point because the Boer Government had nothing to do with this movement. There is a coach service running between Pietersburg and Tuli at this time, and there is a pont on the river. C. H. Zeederbergthe Boers call him "Doul," so do all who know him-has extended the coach service from Pretoria via Pietersburg to Tuli. That coach service together with the Transvaal mail contract is managed by the Zeederberg brothers. The other brother, Piet Zeederberg, resided at Pretoria, and at the present time is a member of the Volkeraad. "Doul" Zeederberg has openly announced at Tuli that the Boers would not enter Chartered territory, that he was not believed is understood 
owing to the prejudices then existing; that he should have been is obvious when you ascertain that he is solely a business man and aiming at the mail contract to Salisbury. This enterprising Dutchman offered to carry the mails and run coaches to Salisbury for $£ 2,000$ a year; and he would place ponts on the rivers. Rhodes and Jameson dallied with the proposal. Zeederberg did eventually run the coaches and mails to Buluwayo, for he pegged at the Chartered Company and won because he was the best man to undertake the business, and had the stock. But if Zeederberg had been allowed to place ponts on the rivers between Tuli and Salisbury, Mashonaland would not have had to undergo the continued famine and famine prices. Zeederberg was right: this was never meant for butcher's bills, i.e., bloodshed. Look to the pseudo-concessionaires. Who are they? Louis Adendorff can at once be dismissed as a pleasant, shrewd man, and as Barend Vorster's lieutenant. A better picture of the engineer-of this movement-Mr. Barend Vorster, jun., is required. He is a swarthy, short man, and goes about on crutches, but all the Boers of Zontspannesberg are afraid of him because they say he is "verdomt slim"-literally "damned clever." What has he done? In 1890 when we were chopping wood as Pioneers he was giving spiders, cape carts, to members and a portrait of the President to the Volkraad-of which he is a 
member-and secured the Selate Railway Concession. This is what Sir Percy FitzPatrick says about it on page 57, "The Transvaal from Within " :- " The Company received $£ 70$ for each $£ 100$ debenture. Comment is superfluous.

the Republic was robbed by a stroke of the pen of $£ 519,000$ - one of the biggest 'steals' even in the Transvaal."

While this demonstration is going on at the Crocodile his emissaries are busy in the Transvaal and the Cape Colony endeavouring to alienate sympathy from Mr. Rhodes-he is the Cape Premier-and advancing his concession claims, which for the sake of peace and justice had better be bought. Then the tide turned against Barend Vorster. A Dutch newspaper denounced him and told the Boers to go home. Sir Henry Loch issued a proclamation, June 1st, 1891, stating that " any attempt by the Boers to invade British territory will be construed as a hostile act against the British Government."

President Kruger followed with a proclamation to the Boers ordering them to desist, and that any such act would be illegal on the part of the burghers, and punishable by the Transvaal Government. These proclamations would stagger most men, but Vorster keeps the Boers togetherhe is rich and determined-for another three weeks, when Ferreira goes over the Crocodile to interview Dr. Jameson. Captain Goody promptly 


\section{PIONEERS OF MASHONALAND.}

made him a prisoner. What exactly passed between Dr. Jameson and Ferreira we don't know, but Dr. Jameson goes over to the Boers with an interpreter and Ferreira, and advises them to appoint a deputation and he would receive them.

Messrs. Senekal, Malan and Marais come over and declare that it is their intention to occupy Banyailand by virtue of a concession, and on those grounds they refuse to comply with any rules and regulations of the Chartered Company whatever. Jameson, point-blank, tells them they would be kept out of the country, and that they had no rights whatever to Banyailand, and suggests that they go home. He lets them see that his police has been reinforced and they get a glimpse of two maxims peaceably glinting in the sunlight. He never wastes words, does this grim and humorous little man, and he knows that $a_{4}$ man on the wrong side of a maxim gun with a weak case convinces himself rapidly. The deputation hurried off, was met by the Boers en masse, and the police and the maxims-especially the maxims-get their full attention. Ferreira follows and advises them to go home-he was the military leader! - and Vorster raves, threatens and cajoles. By way of diversion the maxims start barking. It evokes the trekkers' admi cation and they watch the performance. Vorster's case is gone. He has been outmatched by Jameson. The temper of the erstwhile belligerents is ex- 
cellent, because the Boers open up trading with the troopers and sell them tobacco, Boer-meal and horses. Others ask to join the Police and are ready to sign on for the Chartered Company. Barend Vorster and Adendorff leave as a farewell that they will finish the fight in the law courts and prove the legality of their concession-they have not done so up to date. Ferreira returns to Tuli-by the way, he was made a C.M.G. after the Zulu War. Ostensibly he is a prisoner and dines with the officers, and they get on splendidly. So well, indeed, that he instructs them in syndicate formation and goes to Salisbury with their money. Some of them would like to meet him and square accounts.

With regard to Barend Vorster he has a beautiful farm about ten miles from Pietersberg, and his fertile brain would soon be developing another scheme, for shortly after this there is a case occupying the time of the Judiciaries at Pretoria. The "Only" Jones v. Barend Vorster, jun., and Blencowe. It was a dispute over the ownership of some gold-claims in the Letabi district-that's another story. 


\section{Chapter XXI.}

Mistakes at Tuli-England's Ownership-Suzerainty granted by Lobengula, 1888-Sir Henry Lock's Proclamation, 1891-Chartered Company's correspondence-Lobengula and the Company-The Lippert concession-The Colonial Office-How the Chartered Company disestablished its charter and concession-Great Britain's right to establish Crown Colony in 1893-The Union of South AfricaCopy of the Lippert Concession.

IF Iwere to enlarge on grievances and mistakes I would lose interest, but the reasons for the dearth of provisions and medicines in the land, the first year of occupation, is palpably due to the utter lack of organisation in transport. Again, as the second year is not part of our history, except that the Pioneers approached Mr. Rhodes on this grievous question in Salisbury, in November, 1891 ; it is necessary to go into the loose working of the Chartered Company in the most vital of all things in an isolated country, the food supply.

As Major Leonard kept a diary and as he was at the base of supplies all the time that he was engaged by the Chartered Company I will quote him :-

"It is always better to be on the safe side and have a surplus of commissariat and ordnance supplies than to draw the line too fine and run 
short, and ever since I have been in charge at our advance camp I have been working on this sound and practical principle, but altogether against great odds in :-

(1) The inability of the B.T.A. to supply in sufficient quantities;

(2) Scarcity of transport and difficulty in obtaining it;

(3) The opposition of the Secretary, Rutherford Harris, at Kimberley;

(4) Turner's negligence in failing to supply me with weekly returns.

"The B.T.A. have a contract to supply us, and by our contract we are not at liberty to go elsewhere. However, as they failed according to agreement to forward certain supplies by a given date, I helio'd to Mr. Fry, their manager at Palapye. 'Can you or can you not supply stores as per arrangement. Helio back.' His answer being in the negative and it being imperatively necessary that the goods in question should be forwarded before the rains set in, I immediately made arrangements with Homan, who is agent here for Julius Weil, at Mafeking, to carry out the order, reporting my action in the matter to Rutherford Harris. He, for some reason or other, evidently based on narrow and illogical premises, has forbidden me to receive or forward the supplies. This order I have no intention of obeying, etc. . . . ." Pages 57 and 58, "How we made Rhodesia." 


\section{PIONEERS OF MASHONALAND.}

Here we have the keynote of the situation: The Bechuanaland Trading Association, with its limited capital and meagre transport, are undertaking a work that they cannot perform, and they endeavour to get assistance from Khama in waggons; but as the kaffir transport is inadequate and Palapye only in its second year of occupation, the Pioneers and Police have to starve; and the B.T.A. are waiting until they have made sufficient money to increase their business. As a matter of fact, according to their contract, which includes the mails, they are losing money in fines, on paper, because those fines were never collected. What is the reason for this handin-glove leniency of the Chartered Company to the Bechuanaland Trading Association? The one has a concession in Lobengula's country and the other in Khama's country, and Lord Gifford is a director of the Chartered Company and managing director of the B.T.A Concessions bring hot on their track the iniquities of monopolies, and just as long as monopolies are allowed will the people suffer. It is, however, within the power of the British Government to abolish a monopoly administration of a country over which she has held a suzerainty since 1888, and which was declared British territory on the day of the official occupation by the Pioneer, September 14th, 1890; confirmed still further by the proclamation of Sir Henry Loch in June, 1891; and, further, 
her claim was still more strongly established in 1893, for Colonel Gould Adams and the Bechuanaland Border Police were in the vicinity of the burning capital of Lobengula, as soon as the arrival of the Chartered Company's column. That is, however, a minor point. In 1888 Lobengula agreed with Sir Henry Loch not to dispose of any of his territorial rights to any nation without the consultation and sanction of the British Government, and that agreement established a suzerainty. The people have patiently waited for the expiration of the charter, and self-government is their salvation and hope, and the proper place for Rhodesia is within the Union of South Africa.

She then takes her place in the British Empire as a State, with equal position in that Empire. The renewal of the charter would mean again a company administration, which is not a British form of government, but a species of leasehold; and as a subject swears allegiance to the Crown, and not to a Company, it is a form of alienating the subjects of a mighty Empire; whereas the working of statesmen in the mother country and the Dominions is towards consolidation, and it would be a callous and wicked mistake to shelve the Imperial destinies of a country won by the blood and sinews of the sons of the British Empire, by shunting the Imperial responsibilities of the "Hinterland" again to a monopolistic administration, whose war-cry is $\mathbf{5 0}$ per cent. or 
leave the country: to a people who made the country, founded the country and whose one long hope, for these twenty-five years, has been to see the Union Jack hoisted again, saluted, and the country proclaimed British-not in name-but in actual fact a component part of the British Empire.

Mr. Rhodes in his speeches led one to understand that at the expiration of the charter the country would be taken over as a Crown Colony or be incorporated with the Cape Colony, and it is on that account that he was so largely supported by the Cape railways in extending the line from the south, and by the Cape Government. That the Union of South Africa asked Rhodesia to come in, and that the shareholders of the Chartered Company were disappointed in the refusal, is a matter of recent history. That the Chartered Company, sanguinely obsessed with the gold prospects of the country, hoped to reap an enormous profit out of their 50 per cent. and pay handsome dividends to their shareholders is the sad story of their annual meetings. That their method of false economy, such as having no organised transport or transport of their own, points to their belief in a short tenure of government. That the country is being pulled round steadily-after the decadence of the sanguine $\mathbf{5 0}$ per cent.-by the settlers, who turned their back on the elusive Main Reef, developing the agricul- 
tural prospects of the country, and to-day you find Rhodesian tobacco for sale in your London shops. The time has come, and the time is now, to stand by the settlers and aid them to self-government. It lies with the House of Commons whether the hands of the clock are to be set back and the charter renewed, or whether the British colony will come into its rights and take its place with the other citizens of an illustrious Empire, who twenty-five years ago besmirched its dignity by granting a charter, a form of monopoly that had been dormant for centuries, and a process of administration that had been disastrous to both English and Dutch in the seventeenth century. But there must be no lapsing into lethargy this time, for the great and glorious history of this magnificent Empire shows that its people can govern themselves by a representative government, and that the British rights of a British people demand that their administration be not leased to a body any more than their person given to slavery. It is antagonistic to the freedom of a subject, for his loyalty to his Sovereign remainsthat is a part of himself-but you lease him to a company and the bondage of twenty-five years is more than the sentence of penal servitude for life. The position is clear to anyone who seeks a solution with justice of a position that is not a problem. The Chartered Company must go at the expiration of its charter and Rhodesia become a 
State of the British Empire. She receives $(a)$ Self-government or $(b)$ becomes a Crown Colony.

It is not sufficient to look at a map, gaze at the pink spots and say it is British. Those countries that are ripe for advanced forms of administration must get it, and if we shirk giving it we lower our Imperial status. On beholding that map you find that the Chartered Company can give a good account of her stewardship, and now that she presents her account it must be carefullv scrutinised. The settlers of Rhodesia would never recognise the bill for the second Matabele war, nor the debits of the compensation resulting from that war, as these were due to deliberate maladministration. Her railways' expenditure and her expenses of keeping an armed and mounted body of police must be met, and every just man would like to see that the Company gets a full settlement for that which is her due. I have no grievance against the Chartered Company, and have often wished that she would have paid a dividend for the sake of the shareholders; and I have never held a Chartered Company share. But I am opposed to government by charter, and most emphatically so at this time of the day, when we are not map-painting filibusters, but adherents of direct forms of government and opponents of monopolies.

The resources of the country are a sufficient guarantee for the financier, and with a govern- 
ment security the capital of financiers will be employed to advantage in the development of this, the youngest of England's daughters, and watch her forge her way to steady prosperity, whilst the money of financiers thus employed brings its own reward and not a whole list of calamity, as is the result of capital employed in war development.

The whole question of providing Rhodesia with a government turns on the question of finance, which can readily be found when we consider that the claim of land by the Chartered Company is untenable. That land already belongs to Great Britain, which is easily proved by carefully reading the wording of the concessions, from which the Charter Company affix their claims; and by noting that the crux of the situation was Lobengula, whose power was absolute, and if this case is tried either by British or Kaffir law the result will be the same: that the whole of the territory of Northern and Southern Rhodesia is Crown land, and that up to 1893 the position stood that the country belonged to the potentate Lobengula, and that over this country Great Britain holds a suzerainty dating from the time that Sir Henry Loch, as High Commissioner of the British Government, on the one part, and Lobengula, King and paramount chief of all territories in Matabeleland, Mashonaland and dominions beyond the Zambesi, where his supremacy is recognised by chiefs who pay tribute 


\section{PIONEERS OF MASHONALAND.}

to the aforesaid Lobengula, their liege lord and king, on the other part, agreed that he would not alienate any of his territory except with the authorisation of the High Commissioner. This suzerainty is strengthened by proclamation in June, 1891, when the High Commissioner states that " any attempt by the Boers to invade British territory will be construed as a hostile act against the British Government." Is acknowledged by the Chartered Company who nominate their magistrates, and the same High Commissioner of the British Government, Sir Henry Loch, confirms the appointments. Is further acknowledged in official despatch, the appended letter clearly indicates :-

To the Chief Matoko,

The British South Africa Co., Salisbury.

September 21, 1891.

Mr Friend,-Mr. Selous has told Mr. Rhodes, the Big Induna of all white men in this country, all about you, and he has sent his friend, Mr. Bent, to see you and your people, and to give you some presents from him; and also to tell you that you are now under the Great White Queen, and that the Portuguese will not trouble you any more. You and your people will now live in peace and security.

I am, your friend,

F. Rutherford HarRis,

Secretary. 
On 17th November, 1891-when Mr. Rhodes is at Salisbury, and anxiously inspecting the most favourable mines in the country, and besieged by dissatisfied Pioneers who clamour for an organised transport and a reduction from the 50 per cent. to 25 per cent.-Lobengula-he knows of Rhodes' presence in his dominions-grants to Lippert a concession that "wipes out" the RuddRhodes concession. Later the Chartered Company purchase this concession from Lippert.

It is interesting to note that about this time Alfred Beit is in Rhodesia and that he is a brother-in-law of Lippert and financial adviser to the Chartered Company.

What does Lobengula think of this transaction between Lippert and the Chartered Company? He refuses to receive from the Company the tribute- $£ 500$ per annum-under the concession.

Scrutator of Truth has unearthed this:-

In a telegram addressed to Dr. Rutherford Harris in July, 1892, he said: "I thought you came to dig gold, but it seems you have come to rob me of my people and country as well."

The king steadily refused to recognise Chartered Company's rights, except to dig for gold, and the next year Jameson rides into the country. British troops take possession of the territory of Lobengula, who flees, pursued by Chartered Company agents, who wish to capture him alive. You know the heroic incident of the Shangani, but I 


\section{PIONEERS OF MASHONALAND.}

am confining myself to the business aspect of the case, and throwing light on the indisputable right of Great Britain to Rhodesia. Lobengula dies of fatty degeneration of the heart. Had the obese monarch been captured alive, taken to Groote Schuur, and shared Rhodes' home with him the case would have been different. He might have abdicated in favour of Rhodes and the Imperialist, possibly, would have bequeathed the territories to the British nation. That did not happen.

What did occur was that the sudden demise of the King left the Chartered Company without any legal claim to the country, and the Matabele people without a successor. It was the king's right to nominate his successor when there was no royal heir, as in this case. Lobengula had no son by a royal wife; he would therefore nominate a son by an inferior wife, and the nation would elect the same as their king.

The Chartered Company's claim as concessionaires expired on the day of Lobengula's death, and the Lippert concession became null and void, for Lippert according to the terms of the concession was agent for Lobengula, "in consideration of the payment of $£ 1,000$ and subject only to the annual sum of $£ 500$ being paid to me or my successors in office." Clearly then, as Lobengula had no successor, and as he was the only principal, Lippert's agency terminated at his decease. The Chartered Company, who repre- 
sented Lippert by purchase-without Lobengula's approval-would lose all control of that agency for the same reason.

We are not aware of the Colonial Office having made any blunder in recognising the title to land of the Chartered Company, but the Colonial Office has as much power to grant title to the Company in Matabeleland or Mashonaland as it would have in granting Cornwall to the Jews, because a Semitic race had mined its coast. The Chartered Company again received its charter to acquire land by treaty with the natives. The moment they invaded Matabeleland they broke their charter, because that was the employment of force, and further all the petty chiefs they had treated with in Mashonaland were subject to the Paramount Chief, Lobengula. The Chartered Company therefore have efficiently destroyed their right as a Chartered Company by invasion, and their concession by destroying Lobengula. The Chartered Company receive extenuation from the British Government for that invasion, or, in other words, the troopers of the B.S.A. Company become a British regiment acting on behalf of Great Britain; just as they did when the Chartered Company troopers acted in the Great Boer War as national regiments, and not as company policemen.

Great Britain could have established her right at once in Matabeleland and formed a Crown 
Colony, as she did in the Transvaal. Having granted the Chartered Company administration to the end of her stipulated time the British Government will release the company of its stewardship-that is their position-and give Rhodesia a government for the people by the people. Whether it must go through a form of Crown Colony government first must be decided, but the ultimate result will be self-government and incorporation with the Union of South Africa.

Having disclosed the rights of Great Britain to the territory of Rhodesia, it is time to look at the claim of the Chartered Company. I have gleaned the text of the Lippert Concession from Truth, which you must read carefully.

To those who may be interested in land in Rhodesia it is as well to add-in case of apprehension - that Great Britain will respect all land grants such as farms, church property, mission-stations, native locations, etc., that have been acknowledged or issued by the Company. The Lippert Concession is the claim of the Chartered Company. The text of it reads :-

\section{THE LIPPERT CONCESSION.}

To all to whom these Presents shall come, I, Lo Bengula, King of the Amandabele nation, and of the Makalaka, Mashona, and surrounding territories, send greeting:-

Whereas I have granted a concession in respect of mineral rights, and the rights incidental to mining only, and whereas 
my absolute power as paramount King to allow persons to occupy land in my kingdom, and to levy and collect taxes thereon, has been successfully established; and whereas, seeing that large numbers of white people are coming into my territories, and it is desirable I should assign land to them; and whereas it is desirable that I should once and for all appoint some person to act for me in these respects :

Now, therefore, and in consideration of the payment of one thousand pounds $(£ 1,000)$ having been made to me to-day, I do hereby grant to Edward Amandus Lippert, and to his heirs, executors, assigns, and substitutes, absolutely, subject only to the annual sum of $£ 500$ being paid to me or to my successors in office, in quarterly instalments, in lieu of rates, rents, and taxes, the following rights and privileges, namely :-

The sole and exclusive right, power, and privilege for the full term of one hundred (100) years to lay out, grant, or lease, for such period or periods as he may think fit, farms, townships, building plots, and grazing areas, to impose and levy rents, licences and taxes thereon, and to get in, collect, and receive the same for his own benefit, to give and grant certificates in my name for the occupation of any farms, townships, building plots, and grazing areas; to commence and prosecute, and also to defend in any competent court in Africa or elsewhere, either in my name or in his own name, all such actions, suits, and other proceedings as he may deem necessary for establishing, maintaining, or defending the said rights, powers and privileges hereby conferred; provided always that the said rights and privileges shall only extend and apply to all such territories as now are, or may hereafter be, occupied by, or be under the sphere of operations of, the British South Africa Company, their successors, or any person or persons holding from or under them, and provided that from the rights granted by these presents are excluded only the grazing of such cattle, the enclosing of such land, 


\section{PIONEERS OF MASHONALAND.}

and the erection of such buildings and machinery as are strictly required for the exercise of the mineral rights now held by the British South Africa Company under the said concession.

The powers granted to E. Ramsay Renny Tailyour, under date of 22nd April, 1891, are hereby withdrawn and cancelled in so far as they are in conflict with these presents.

Given under my seal at Umvutcha this 17th day of November, 1891.

Witnesses :-

(Signed)
Elephant

Seal

Lo Bengula.

E. R. Renny-TaILyour, J AMES RILEY, James Fairbairn, (James Umkisa's cross). (Signed) Ed. A. Lippert. 


\section{Conclusion.}

The first Administrator leaves-Dr. Tabiteau-Dr. RandPioneers' dissatisfaction-Rand, the People's ChampionRhodes - B.S.A. Company's Director - The Company courting the Rhodesians-Mr. Rochefort McGuire as best man-Mother 50 per cent.-The traditions of the House of Commons-The spirit of Hampden.

The little band of one hundred and eighty-four men have thinned out considerably: some are dead, others exhausted with fever leave the country because they are too weak to go through another fever season with any chance of recovery. Some came back, the majority did not. The Excelsior Syndicate dissolved partnership and left the Mashonaland Main Reef to its fate. Major Forbes gave us a good price for the waggon and donkeys that Nowers brought up, as transport is scarce. Brand, Adcock and Nowers have already left the country. Our Administrator. Colquhoun, left on August 6th; and Dr. Tabiteau was invalided in August to England. I have made no mention of Dr. Rand as yet, but he came up with the Police at the same time as the Pioneers. He has been down to Umtali and is back at Salisbury, and is one of the principal agitators for reform. A little keen-faced man, slightly deaf, clever and 
high-principled. The Pioneers want to know again why provisions are so scarce in the country, and they want to get a reduction of the 50 per cent. to 25 per cent. Dr. Rutherford Harris has established the office of secretary at Salisbury, transferred himself from Kimberley. He bathes in the swimming hole near Salisbury one day, and a crocodile takes a piece out of his anatomy. He subsequently sat for Dulwich in the House of Commons, so the inconvenience was temporary; but he did a lot of blasting over that crocodile and wasted a good deal of dynamite.

September has arrived and the Pioneers celebrate the anniversary of the occupation of Mashonaland with a gigantic meeting of protest.

The result is that Jameson sends Selous down to ascertain what waggons are coming up. Dr. Jameson has no taste for official work and Dr. Harris seems to be absorbed with the dignity of his office; whilst at Tuli Major Tye is commissariat officer, transport officer, paymaster and magistrate. The only gold in Mashonaland worth recording Major Tye found, and he took it with him, for it did not take him very long to retire from business. Dr. Rand can put his finger on all the festering sores, but the authorities do not heed. The mantle of John Hampden has fallen on Rand's shoulders, and the company officials maintain taxation, the 50 per cent. and misrule. The energtic and resourceful physician, who is 
the leading medical officer of the country, resigns his position in the B.S.A. Company and practices amongst the Pioneers and settlers-becomes of the people. The general impression amongst the people is that Rhodes will rectify matters, and they await his arrival. The self-styled "Father of the People" arrives and meets a deputation of the people. He will not entertain the reduction of 50 per cent. to 25 per cent., and in answer to provisions asserts there are pumpkins and beans which can be traded from the natives. Dr. Rand replies that fever and dysentery patients cannot be kept alive on such a diet. Rhodes enthusiastically affirms that the wire is coming up. "Look what I have done, a wire from Salisbury to Capetown, and in touch with England in a very few months. You cannot have everything at once."

As to that wire, it was being pushed up because of the enormous expenditure in human life and horse-flesh between Tuli and the Lundi. The Police despatch-riders sleep along the Selous road and are the milestones of British pluck on this route. The death of the horses is due to the terrible horse-sickness that rages through the lowlying country in the summer months, when fever is rife. It never occurred to Rhodes or Jameson to run a wire temporarily on a field-service system. Pietersberg was $\mathbf{1 9 0}$ miles from Tuli and had the telegraph there. The Chartered Company 


\section{PIONEERS OF MASHONALAND.}

could have established a code if they did not want Transvaal telegraphists to interpret their messages. But as Rhodes was on amicable terms with the Transvaal and had taken coffee with the President on the famous stoep only twelve months ago, these precautions were not necessary.

From that day the Pioneers stood alone, and knew that Rhodes meant the Company, but in 1896 he stood with the people, for he grasped the situation quickly. Dr. Jameson had taken the troopers out of the country and gone south. The Matabele rose and massacred the people. The people broke open the B.S.A. Company's armoury and openly avowed that unless compensation was paid they would take the country and do without the Chartered Company. The telegraph wire was of use then, because Rhodes' message rang: "Compensation must be paid."

The representatives allowed the people by election do not go far in Rhodesia's Legislative Assembly because the Company hold a majority by nomination.

The Chartered Company has sent Mr. Rochefort McGuire on a honeyed campaign through Rhodesia to promise that the representation of the people will be increased to a majority on the Council, to forego the $7 \frac{1}{2}$ millions war expenses, which the people had refused to recognise, as a just item in their bill, since 1896. To institute a generous land policy, and to facilitate matters so 
that the Company can gradually withdraw and the people take over control.

The object of Mr. Rochefort McGuire's suave assurances is to get the people to stand by the Chartered Company, and that, with their position thus strengthened, the House of Commons would renew the charter-then the people can wait. The generous land policy proposed is a means by which the Chartered Company can sell the people land which belongs to the British Government. and that question must be solved once and for all time.

Mother 50 per cent. has given us too much brimstone and too little treacle, and we have grown to despise treacle. Her definition of pacifist, a good one, but the accent is on the last syllable : is out of date. She has jumped over the fence and quarrelled with all her neighbours, but she has kept her house in order, and now that her lease has expired the British Government will collect its ground rent, get its title deeds in order; compensate the old lady for work done. and give her an old-age pension. Rhodes sleeps on the Matoppo heights, and he has been described as the "Father of the People" to the natives, and let it rest there. As long as the natives are content with tribal government and do not understand freedom they must have that form of government which they prefer; but you cannot treat white men like kaffirs, for their education 


\section{PIONEERS OF MASHONALAND.}

and traditions are British, and they have the same right to Home Rule as any other province in South Africa. I cannot conceive the gentlemen of the Treasury Bench, whose party is allied to the history of the freedom of the English people, whose policy is to increase the freedom of the British subjects, and whose gift of self-government to South Africa is recent history, denying freedom and self-government to Rhodesia, and sentencing them to a further term of bondage under company administration. I cannot conceive the gentlemen of the Opposition Bench, whose traditions are connected with the increase of power and the dignity of the Empire, jeopardising the right and title of Great Britain to her property and allowing themselves to be outwitted by a company.

I do perceive a spirit in the House of Commons and a writing on the wall. This writing is not cuneiform, to puzzle members, it is plain sound British, and the letters spell freedom; and the spirit that is leading us is that of a great statesman to whom Selous led us, but the Chartered Company halted us and gave us a Salisbury This spirit found, us, and has been tutoring us in moderation, patience and courage these twentyfive years, for Hampden was here before Salisbury, and the spirit of Hampden is with you in the House of Commons, and he is the "patrix pater" that you acknowledge and that we rever- 


\section{PIONEERS OF MASHONALAND. 197}

ence. Father of you, father of us, let his spirit plead for us; and standing in the Mazoe valley the historian can say that which Green said of Hampden's home:-

"A country of fine and lucid air, of far shadowy distances, of hollows tenderly veiled by mist, graceful everywhere with a flowing unaccentuated grace, as though Hampden's own temper had grown out of it."

The End. 
198 PIONEERS OF MASHONALAND.

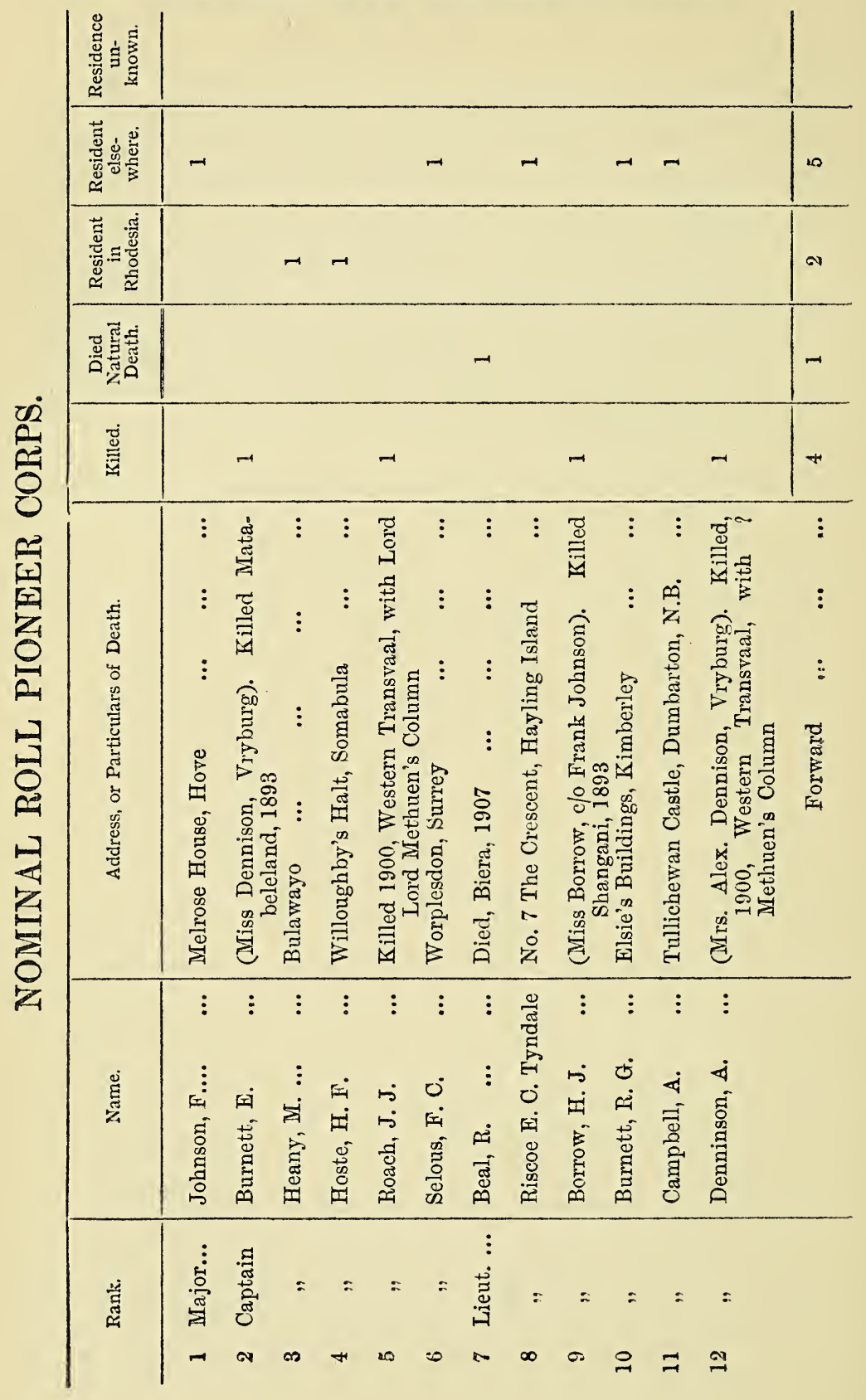


PIONEERS OF MASHONALAND. 199

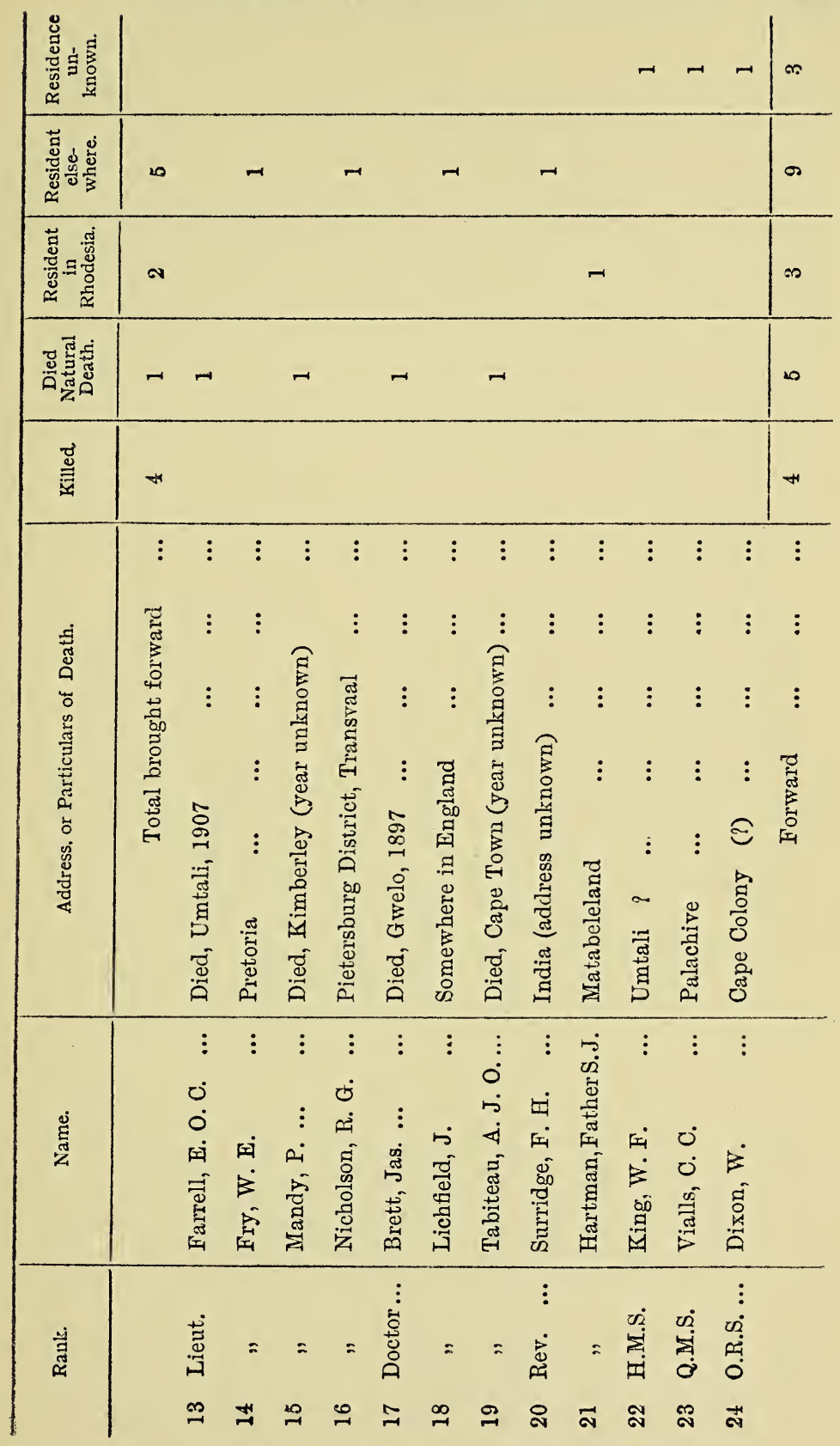


200 PIONEERS OF MASHONALAND.

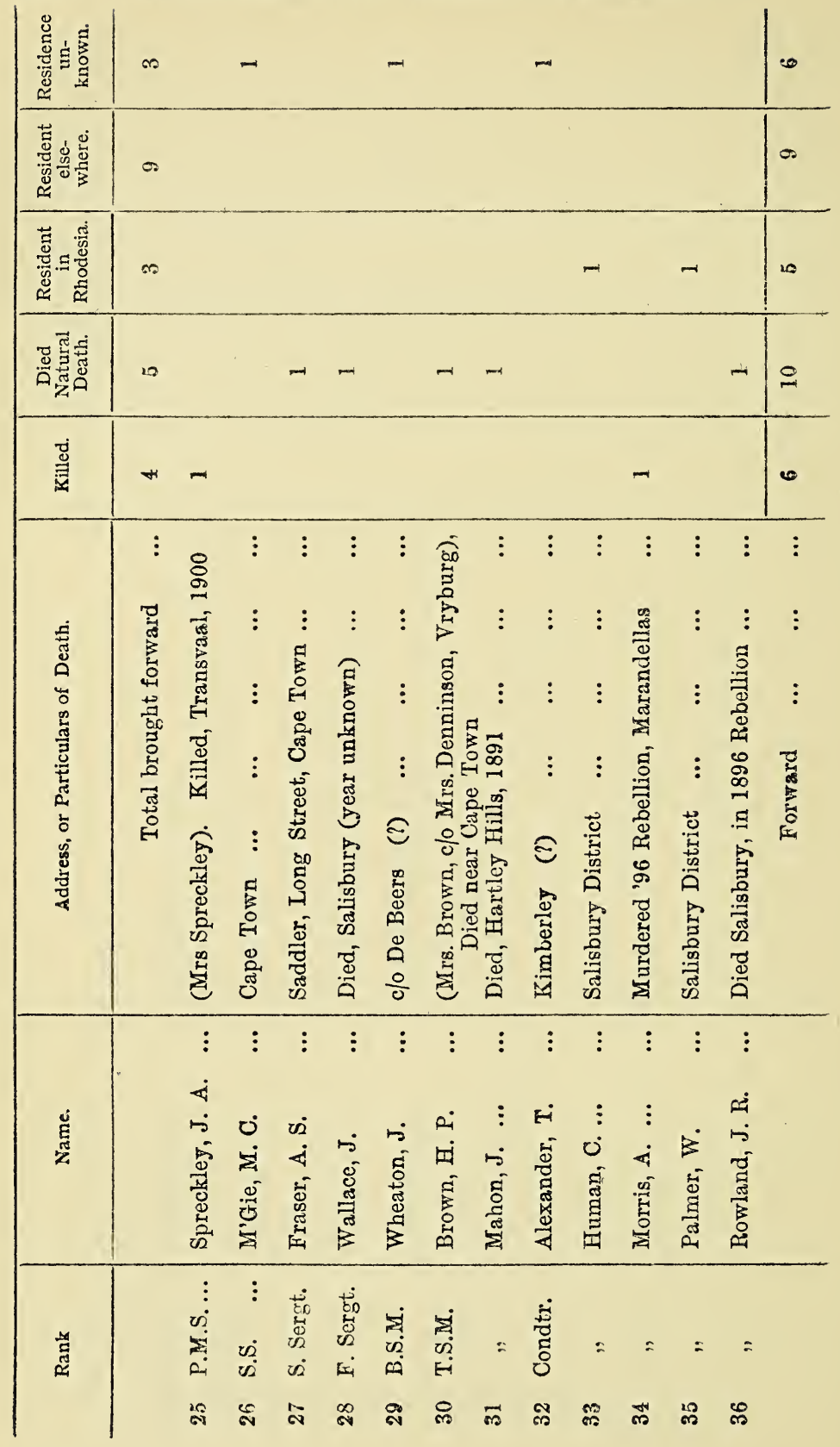


PIONEERS OF MASHONALAND. 201

\begin{tabular}{|c|c|c|c|c|c|c|c|c|c|c|c|c|}
\hline 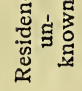 & 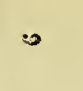 & & - & & & & -1 & & & & 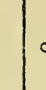 & \\
\hline 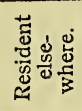 & $\theta$ & & & & & & & & & - & . & \\
\hline 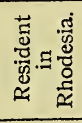 & $\therefore$ & & & & & & & -- & & & $n$ & \\
\hline 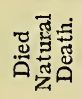 & $\therefore$ & & & - & & & & & & & 4 & \\
\hline 总 & . & & - & & & - & & & - & & 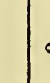 & \\
\hline 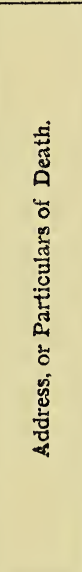 & 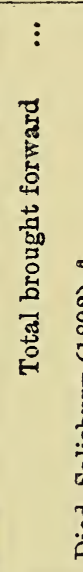 & 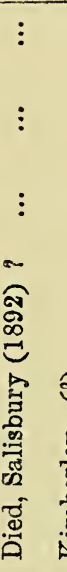 & 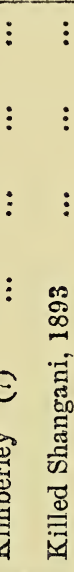 & 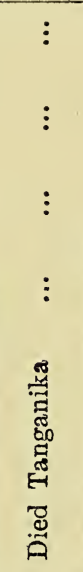 & 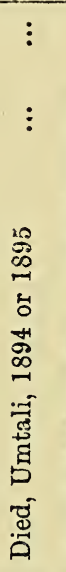 & 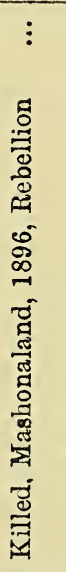 & $\begin{array}{l}\vdots \\
\vdots \\
\vdots \\
\vdots\end{array}$ & 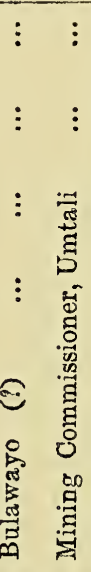 & 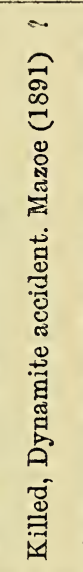 & 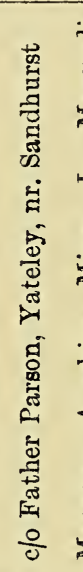 & 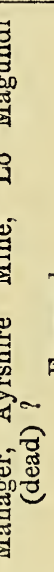 & \\
\hline 突 & & 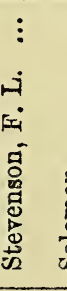 & 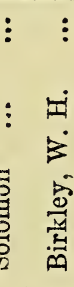 & 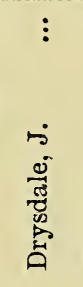 & 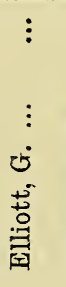 & 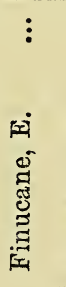 & 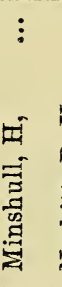 & 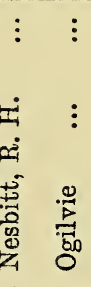 & 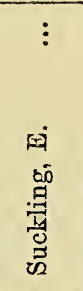 & 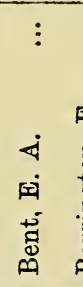 & : & \\
\hline 嗬 & & 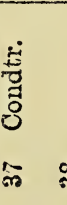 & 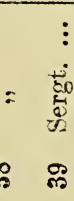 & $=$ & $\begin{array}{l}= \\
=\end{array}$ & $\begin{array}{l}\text { : } \\
\text { มี }\end{array}$ & & $\begin{array}{l}:= \\
\text { IH }\end{array}$ & $\begin{array}{l}= \\
\mathscr{f}\end{array}$ & $\begin{array}{l}\vdots \\
\vdots \\
\dot{\vec{d}} \\
0 \\
0\end{array}$ & & \\
\hline
\end{tabular}


202 PIONEERS OF MASHONALAND.

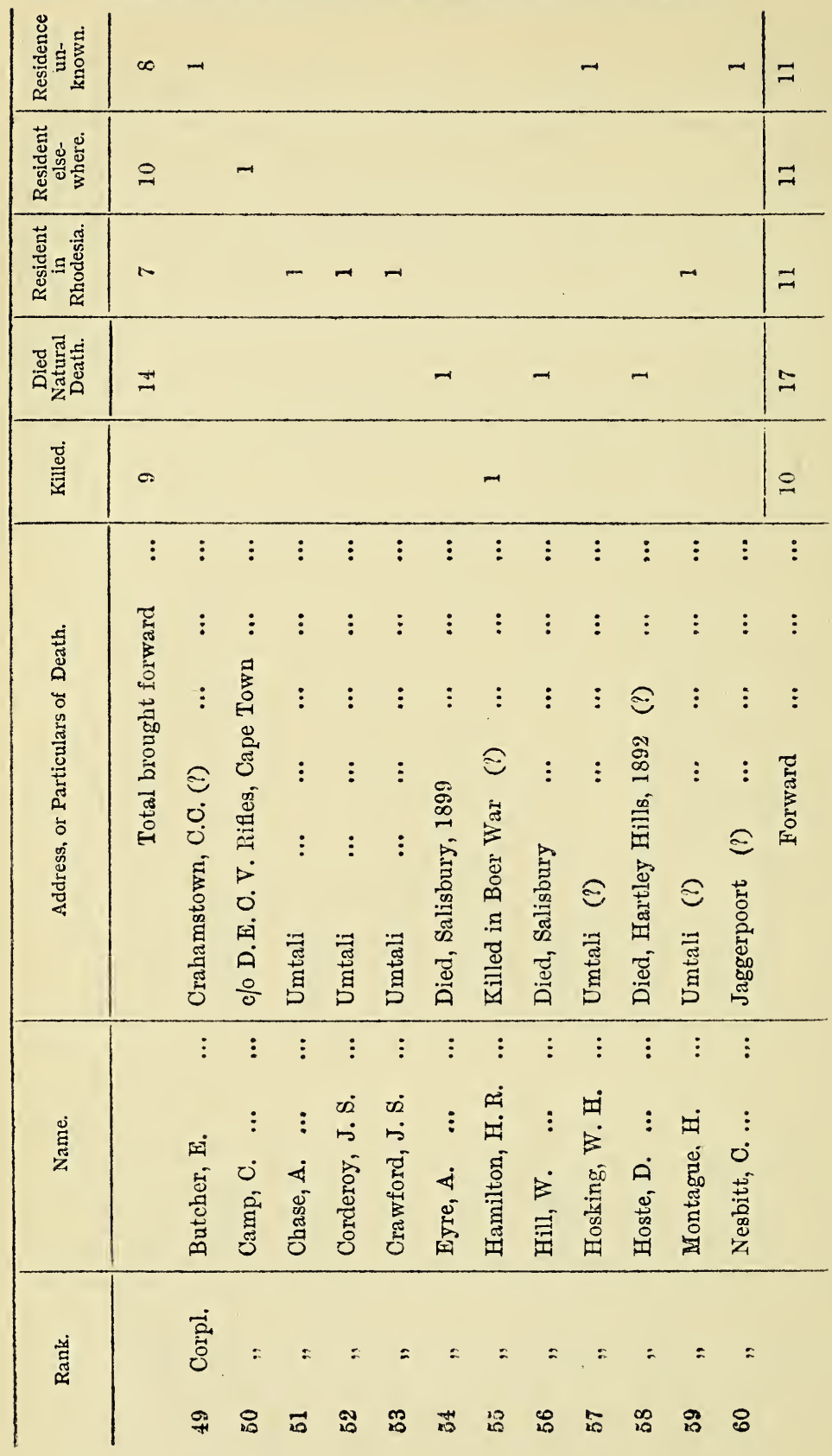


PIONEERS OF MASHONALAND. 203

\begin{tabular}{|c|c|c|c|c|c|c|c|c|c|c|c|c|}
\hline 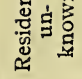 & $\Rightarrow$ & - & & -1 & - & & & - & & & & $\approx$ \\
\hline 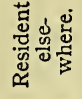 & 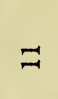 & & & & & & & & & & - & $\approx$ \\
\hline 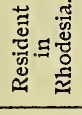 & $=$ & & & & & & - & & & . & -1 & $\stackrel{m}{-1}$ \\
\hline 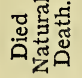 & $\approx$ & & -7 & & & $\sim$ & & & & & & ㅇ \\
\hline 离 & $\stackrel{9}{2}$ & & & & & & & & & & & 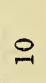 \\
\hline 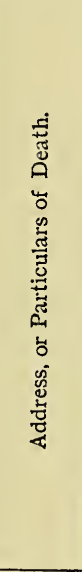 & 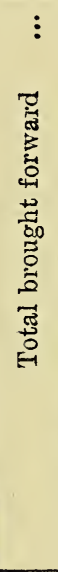 & 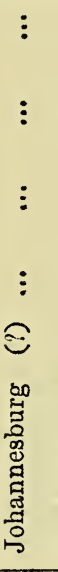 & 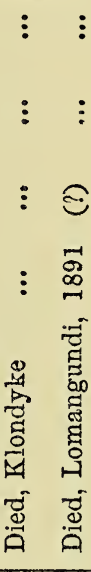 & 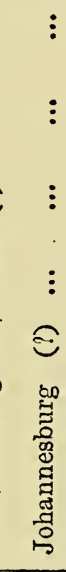 & $\begin{array}{l}\vdots \\
\vdots \\
\vdots \\
\vdots \\
-\end{array}$ & 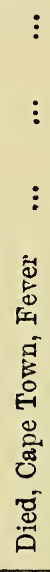 & 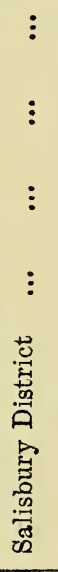 & 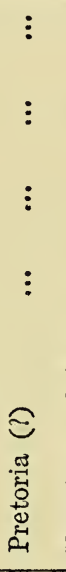 & 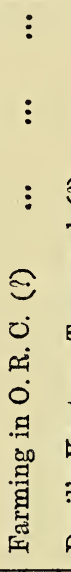 & 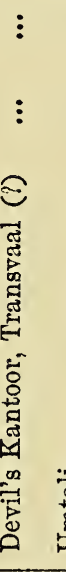 & $\begin{array}{ll}\vdots & \vdots \\
\vdots & 0 \\
\vdots & 0 \\
\vdots & 0 \\
0\end{array}$ & $\begin{array}{l}\vdots \\
\vdots \\
\vdots\end{array}$ \\
\hline 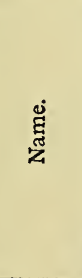 & & 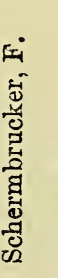 & 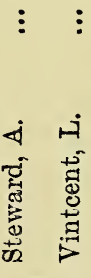 & $\begin{array}{l}\vdots \\
8 \\
8 \\
\frac{8}{8} \\
\frac{8}{4}\end{array}$ & 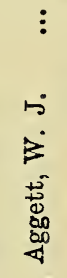 & 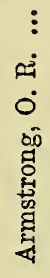 & 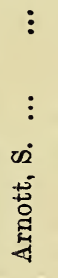 & 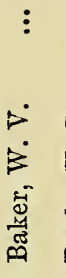 & 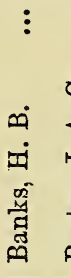 & $\begin{array}{l}\vdots \\
0 \\
\dot{0} \\
\dot{4}\end{array}$ & 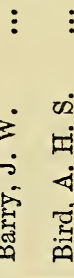 & \\
\hline 塸 & & & $\begin{array}{l}= \\
\& 8 \\
\& 8\end{array}$ & $\begin{array}{l}\text { 岕 } \\
\text { 品 }\end{array}$ & $=$ & & $\approx$ & $=$ & & & & \\
\hline
\end{tabular}


204 PIONEERS OF MASHONALAND.

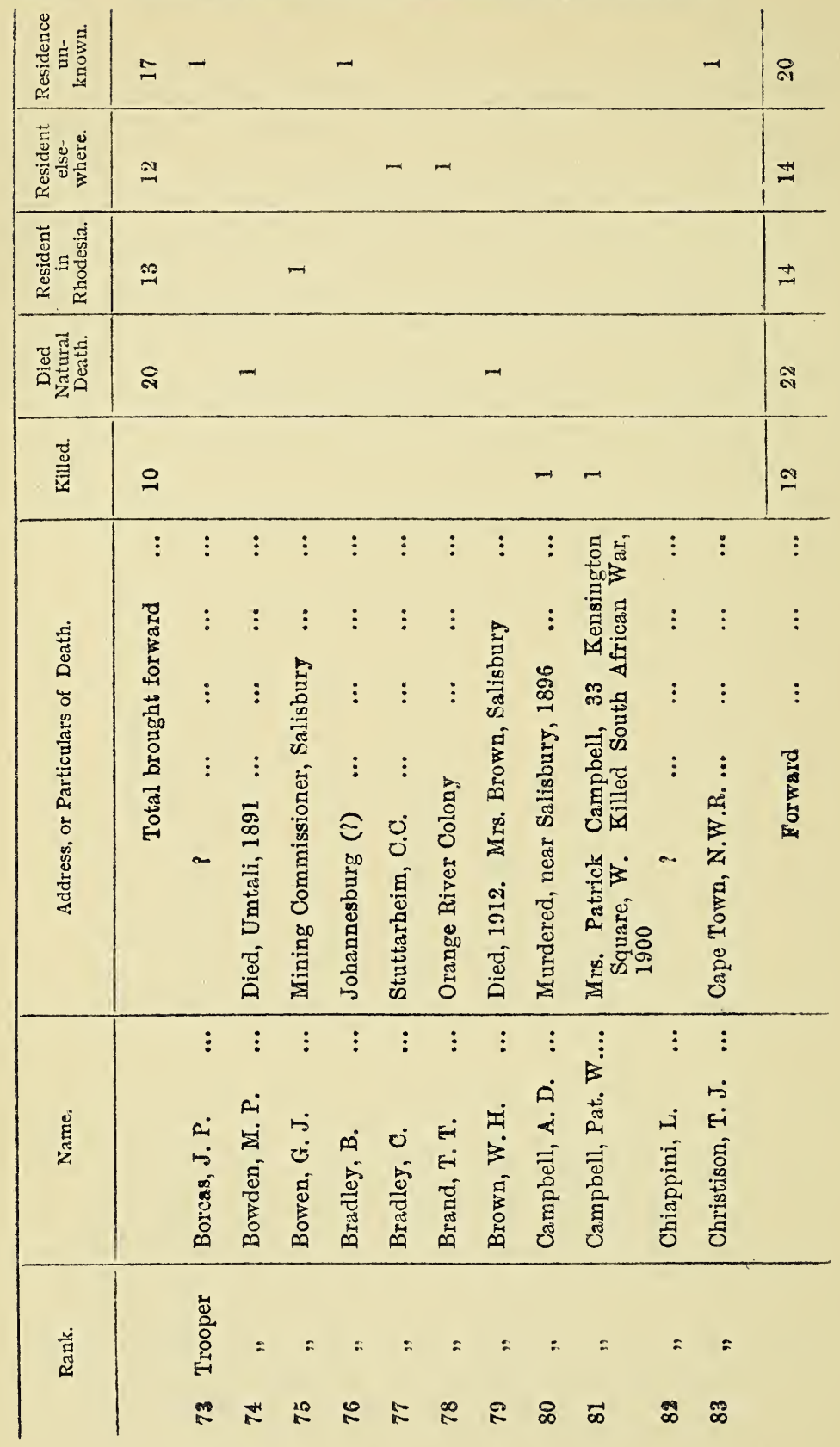


PIONEERS OF MASHONALAND. 205

\begin{tabular}{|c|c|c|c|c|c|c|c|c|c|c|}
\hline 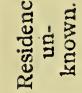 & $\therefore-$ & - & & - & - & & & & & \\
\hline 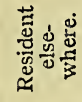 & \pm & & & & - & & & - & & \\
\hline 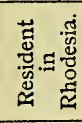 & $\#$ & & & & 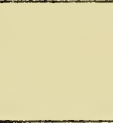 & & 7 & & & -1 \\
\hline 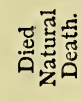 & จ & - & & & & & & & & \\
\hline & $\cong$ & & & & & & & & & \\
\hline & 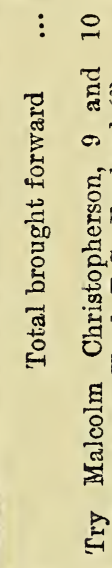 & 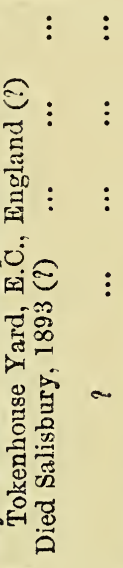 & $\vdots$ & 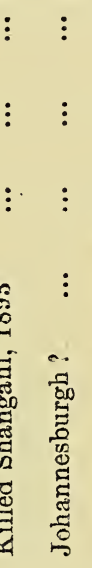 & 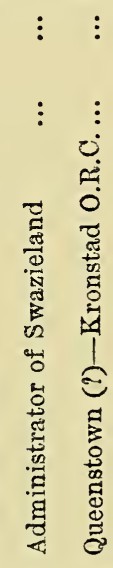 & & & & $\begin{array}{l}0 \\
\square \\
\square\end{array}$ & 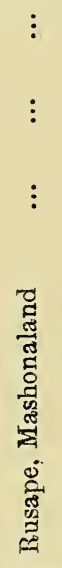 \\
\hline$\frac{5}{2}$ & & 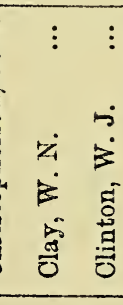 & 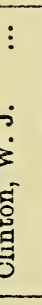 & 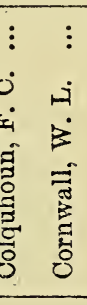 & 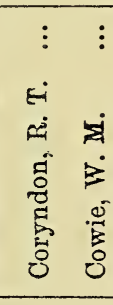 & & & & & 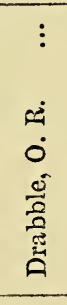 \\
\hline $\mathbb{2}$ & & $=$ & & & & & & & & \\
\hline
\end{tabular}


206 PIONEERS OF MASHONALAND.

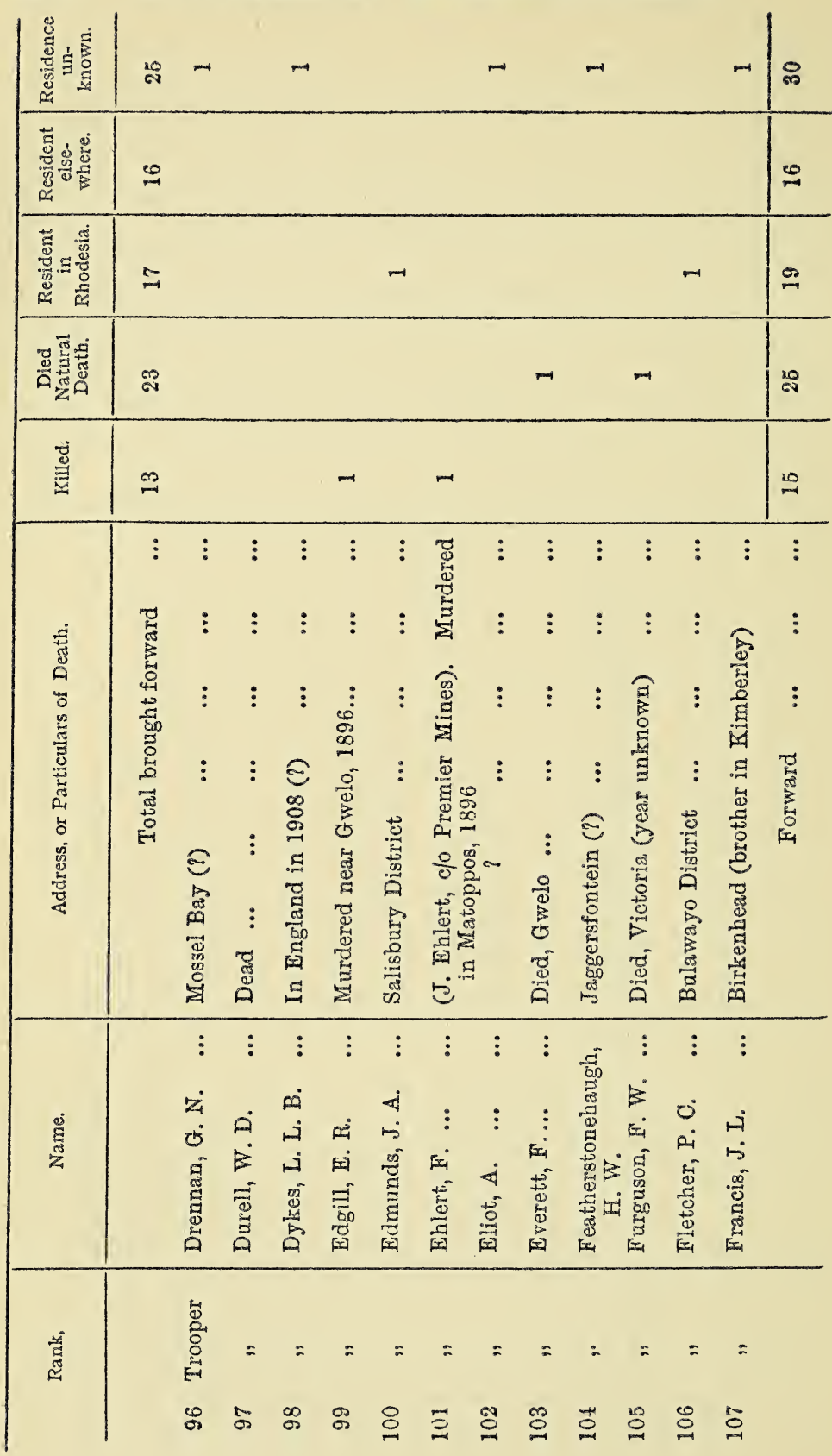




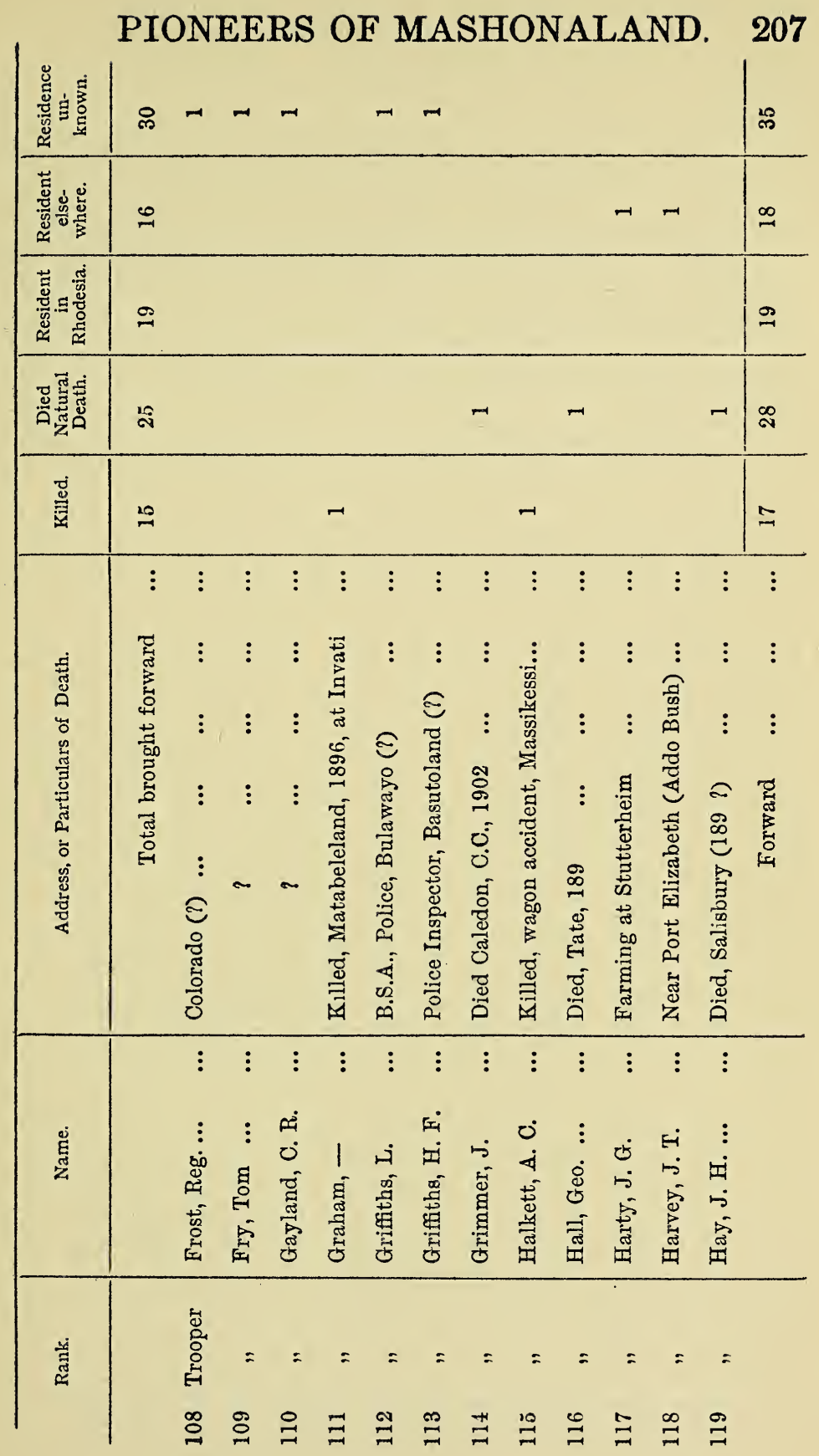


208 PIONEERS OF MASHONALAND.

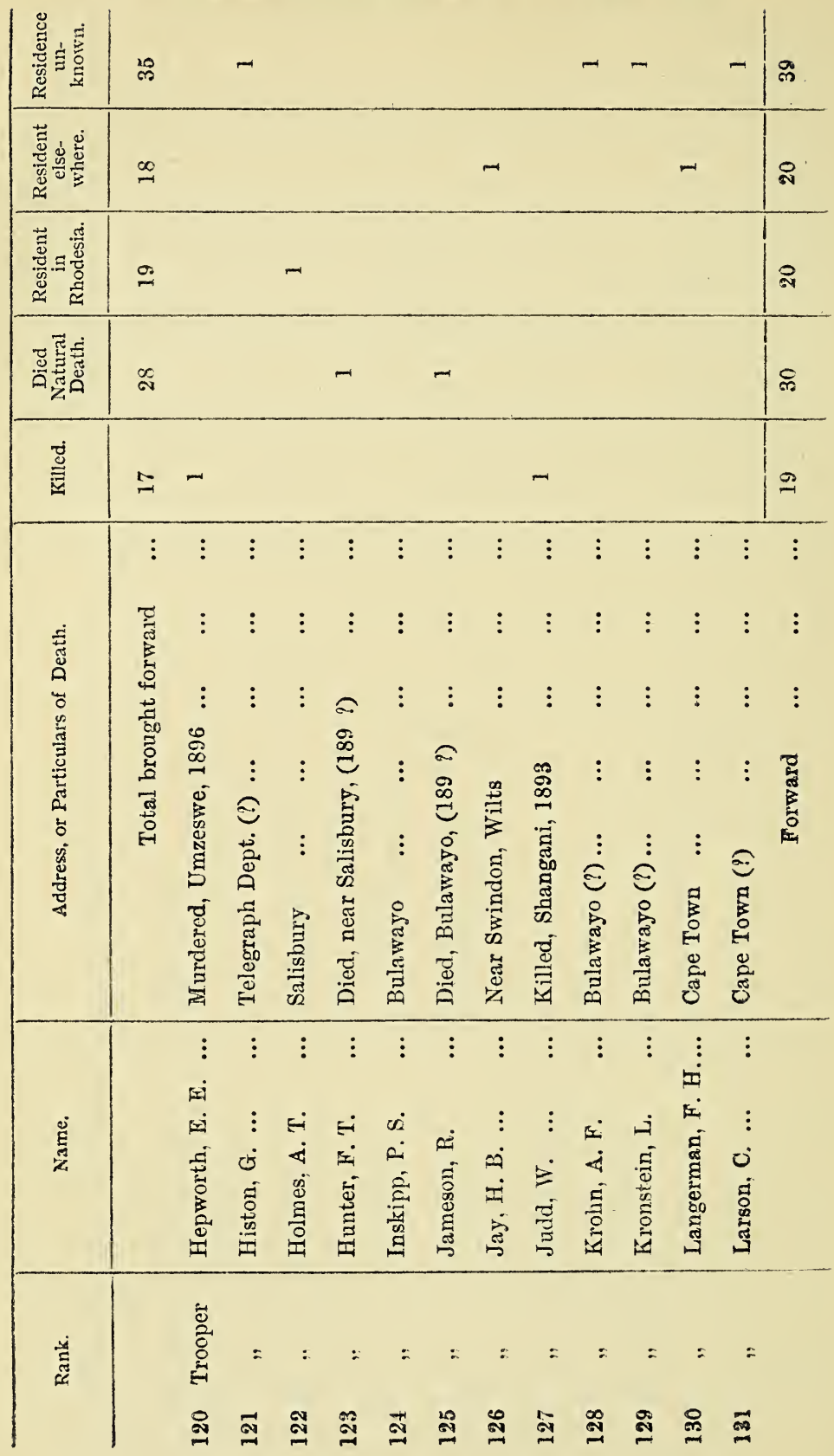


PIONEERS OF MASHONALAND. 209

\begin{tabular}{|c|c|c|c|c|c|c|c|c|c|c|c|c|c|}
\hline 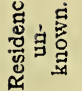 & శో & & & & & 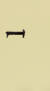 & & - & & - & -1 & & 19 \\
\hline 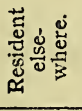 & ๙ి & & & & & & - & & - & & & & ร \\
\hline 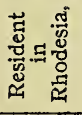 & ๙ิ & & - & & & & & & & & & & ล \\
\hline 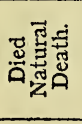 & 8 & & & - & & & & & & & & 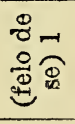 & $\approx$ \\
\hline 离 & $\Xi$ & & & & & & & & & & & & ๑ \\
\hline 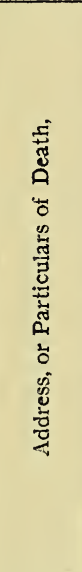 & 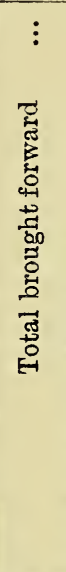 & 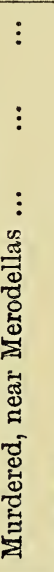 & 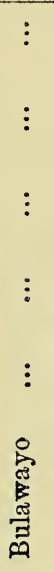 & 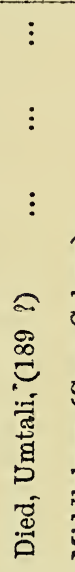 & 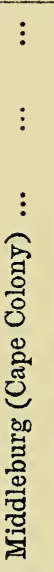 & 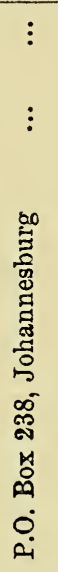 & 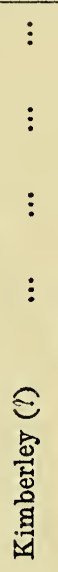 & 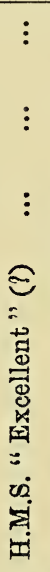 & 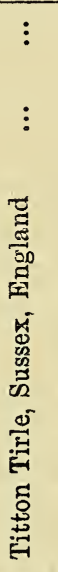 & 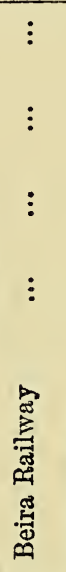 & 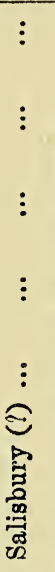 & 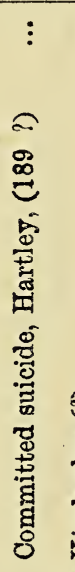 & 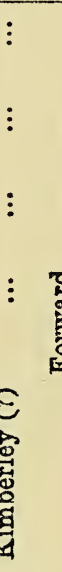 \\
\hline 昜 & & 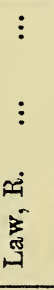 & 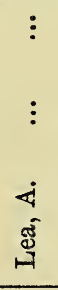 & 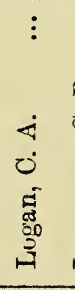 & 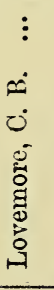 & 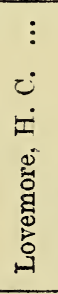 & 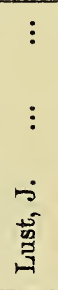 & 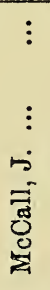 & 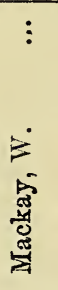 & 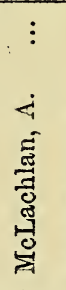 & 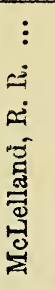 & 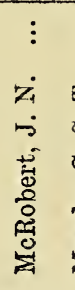 & 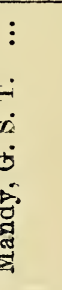 \\
\hline 苞 & & 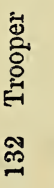 & 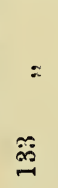 & $\begin{array}{c}= \\
\overrightarrow{\vec{g}}\end{array}$ & 嶌 & : & $:$ & $\stackrel{\infty}{\stackrel{一}{\sim}}$ & $=$ & $\begin{array}{l}= \\
\text { 욮 }\end{array}$ & $\bar{I}$ & & $=$ \\
\hline
\end{tabular}




\section{PIONEERS OF MASHONALAND.}

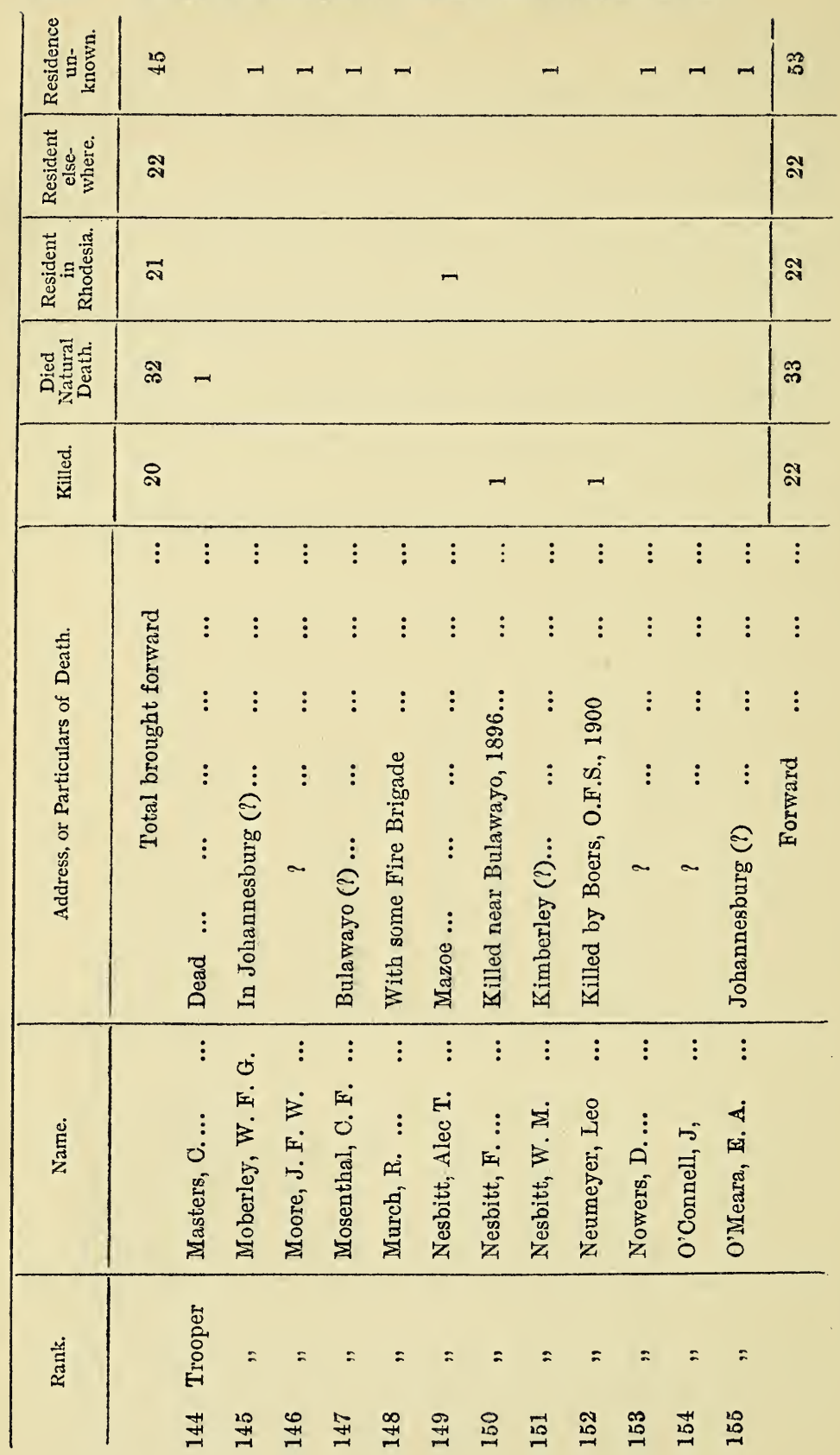




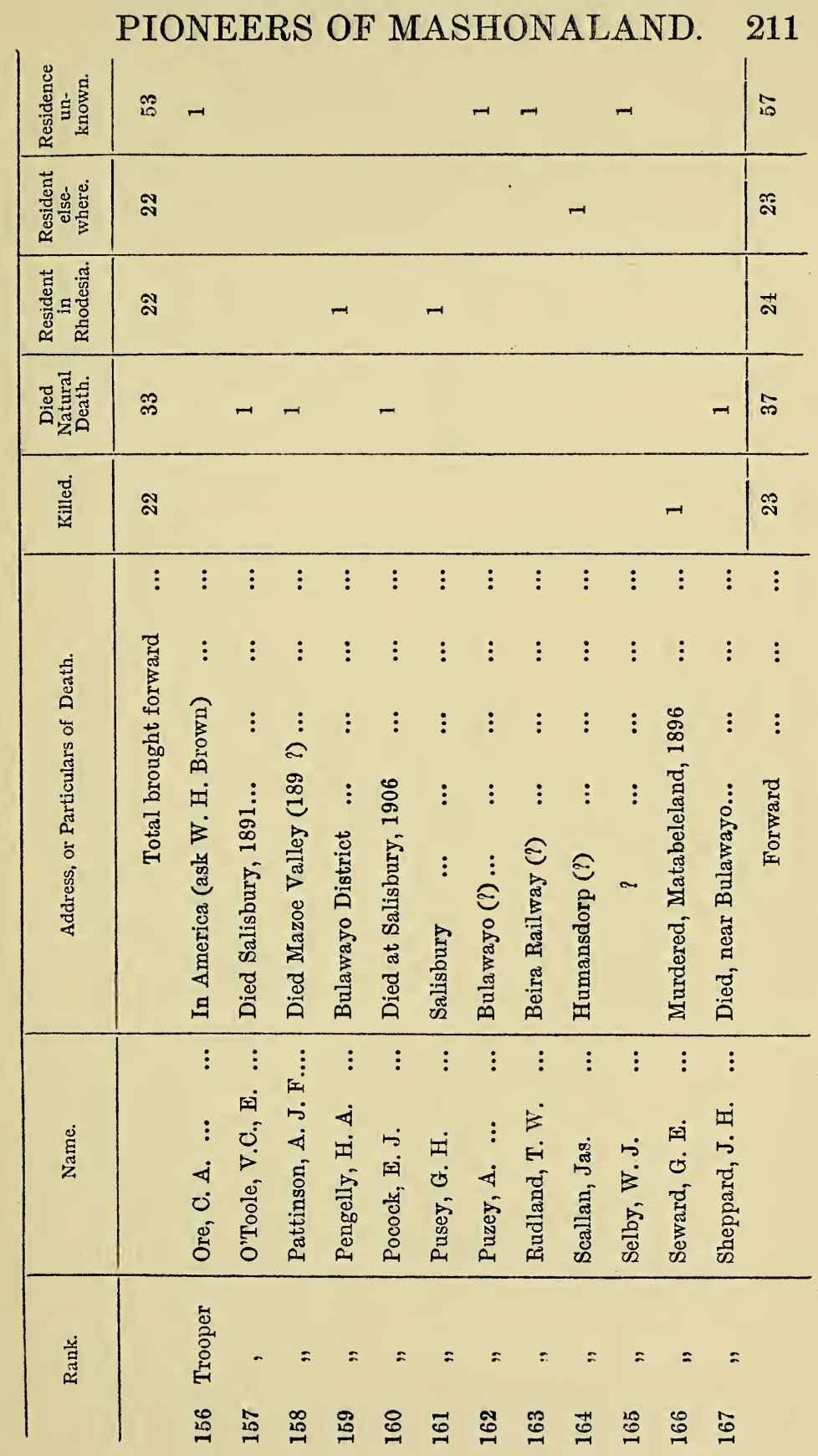




\section{PIONEERS OF MASHONALAND.}

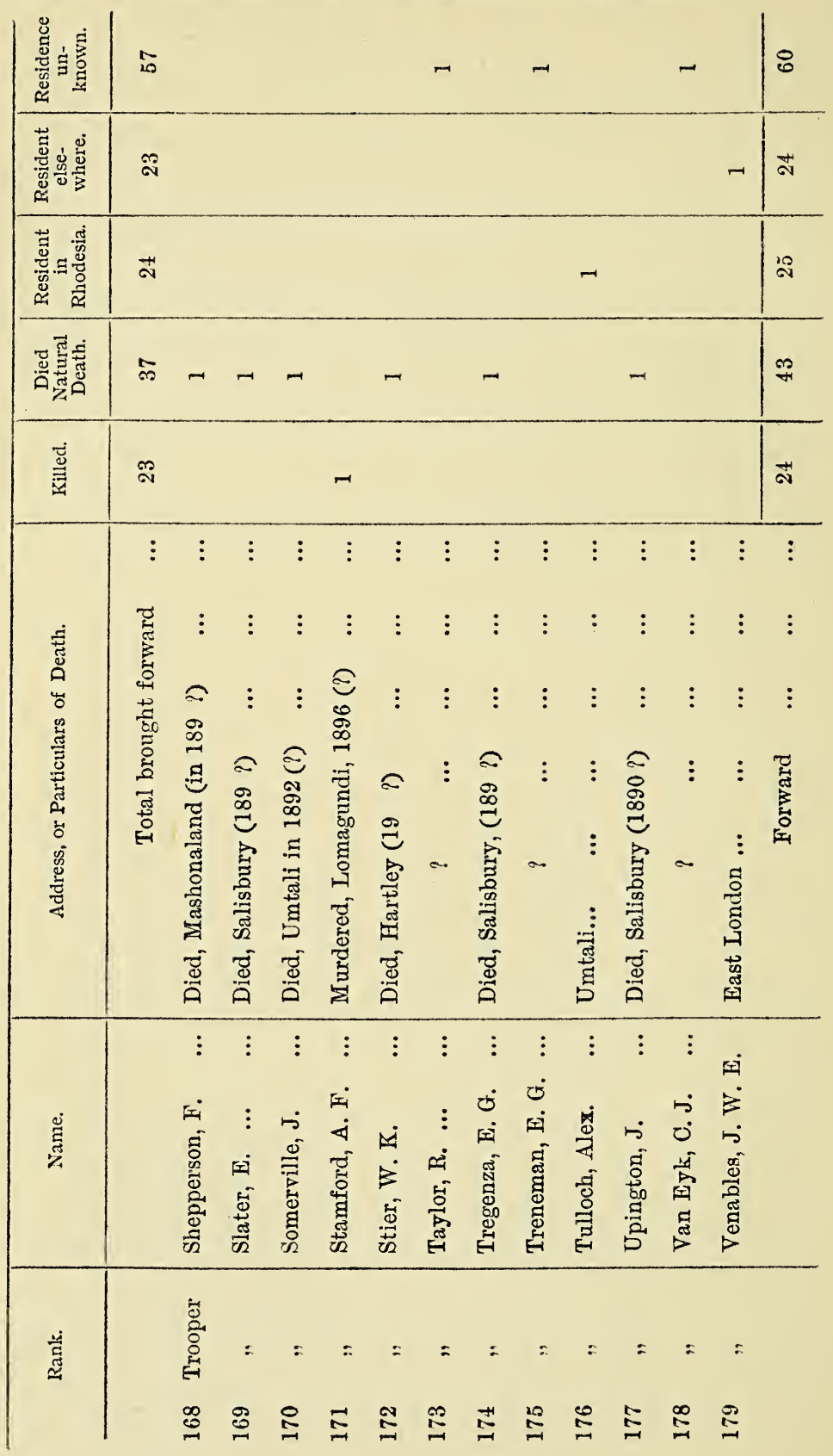


PIONEERS OF MASHONALAND. 213

\begin{tabular}{|c|c|c|c|c|c|c|c|c|c|c|c|}
\hline 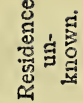 & 8 & -1 & -1 & - & & & & & & : & \\
\hline 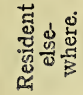 & 茫 & & & & & -1 & & & & 'ૈิ & \\
\hline 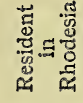 & $\stackrel{2}{\circ}$ & & & & & & & & & \&ి & \\
\hline 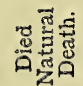 & 泫 & & & - & & & & & & $\#$ & \\
\hline 离 & त̈ & & & & & & & & & $\vec{\omega}$ & 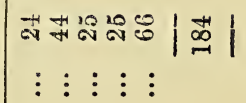 \\
\hline 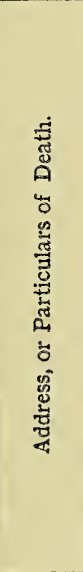 & 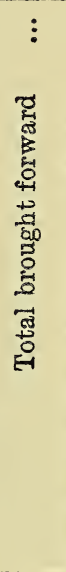 & 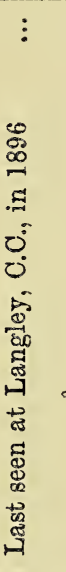 & $\begin{array}{l}\vdots \\
\vdots\end{array}$ & 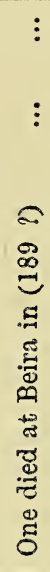 & & 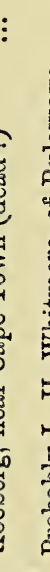 & 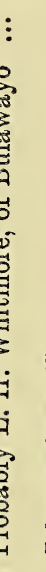 & 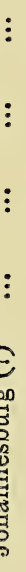 & $\vdots$ & $\begin{array}{l}\vdots \\
\vdots \\
2\end{array}$ & 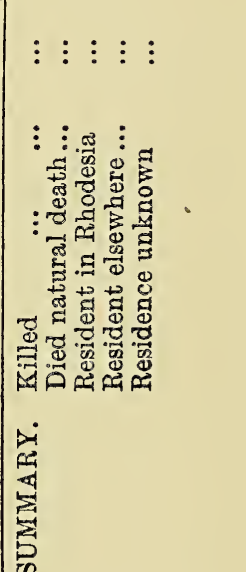 \\
\hline 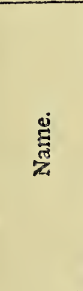 & & 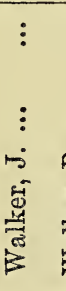 & 文 & , & & 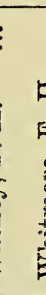 & 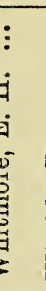 & $\begin{array}{l}\vdots \\
\dot{a} \\
b^{\prime}\end{array}$ & $\begin{array}{l}0 \\
4 \\
4\end{array}$ & & \\
\hline 茪 & & 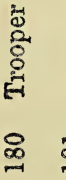 & & & & & 密 & & & & \\
\hline
\end{tabular}







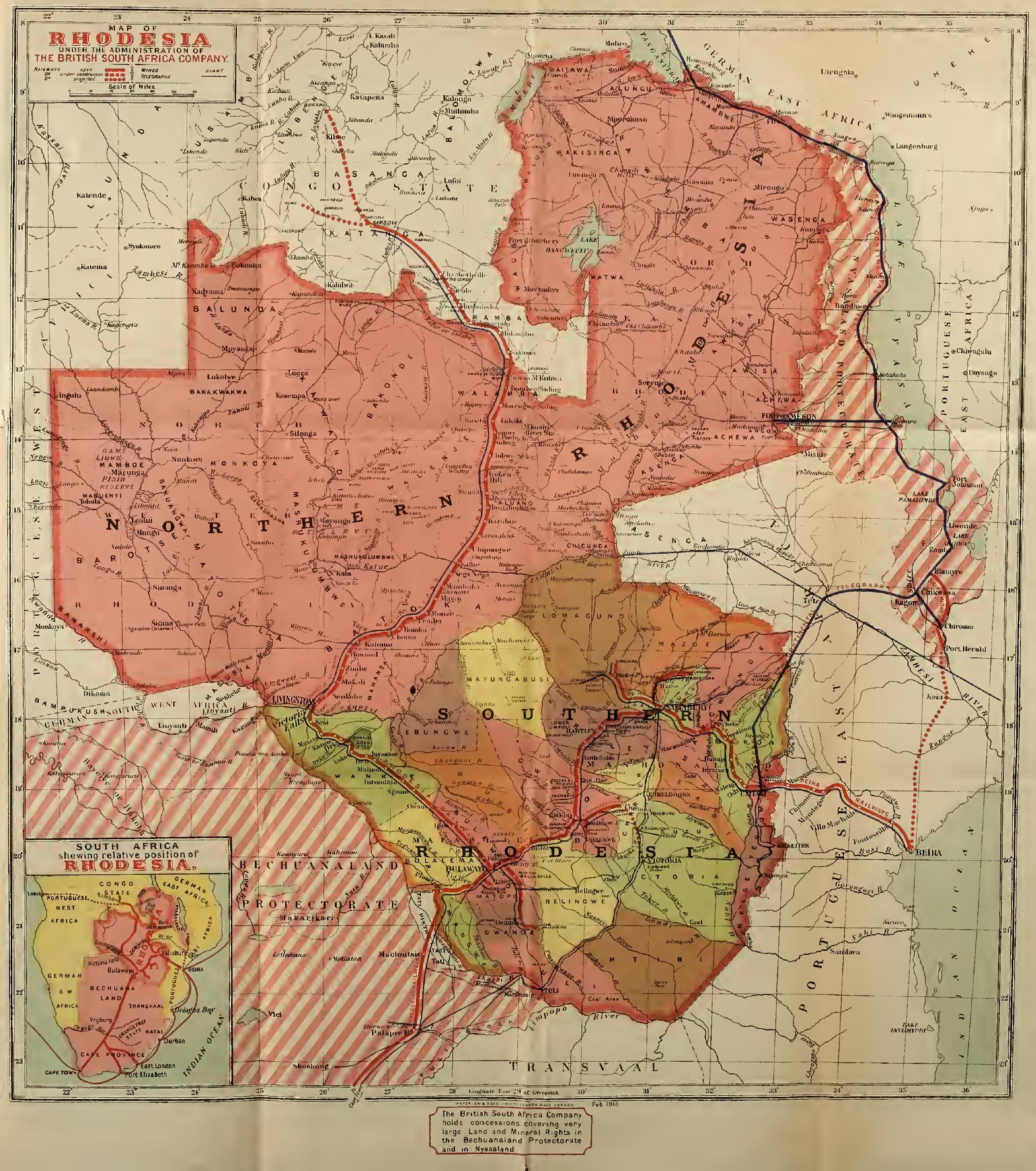







mongers.

है से

sereq

$545 \%$

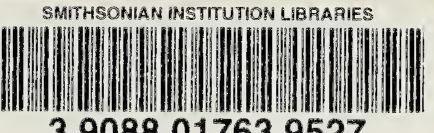

39088017639527

Antso

$a^{50^{\circ}}$ 


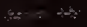

- wectersed obseren.

$\therefore$ 